\title{
SUMMER FLOWERS OF THE HIGH ALPS
}

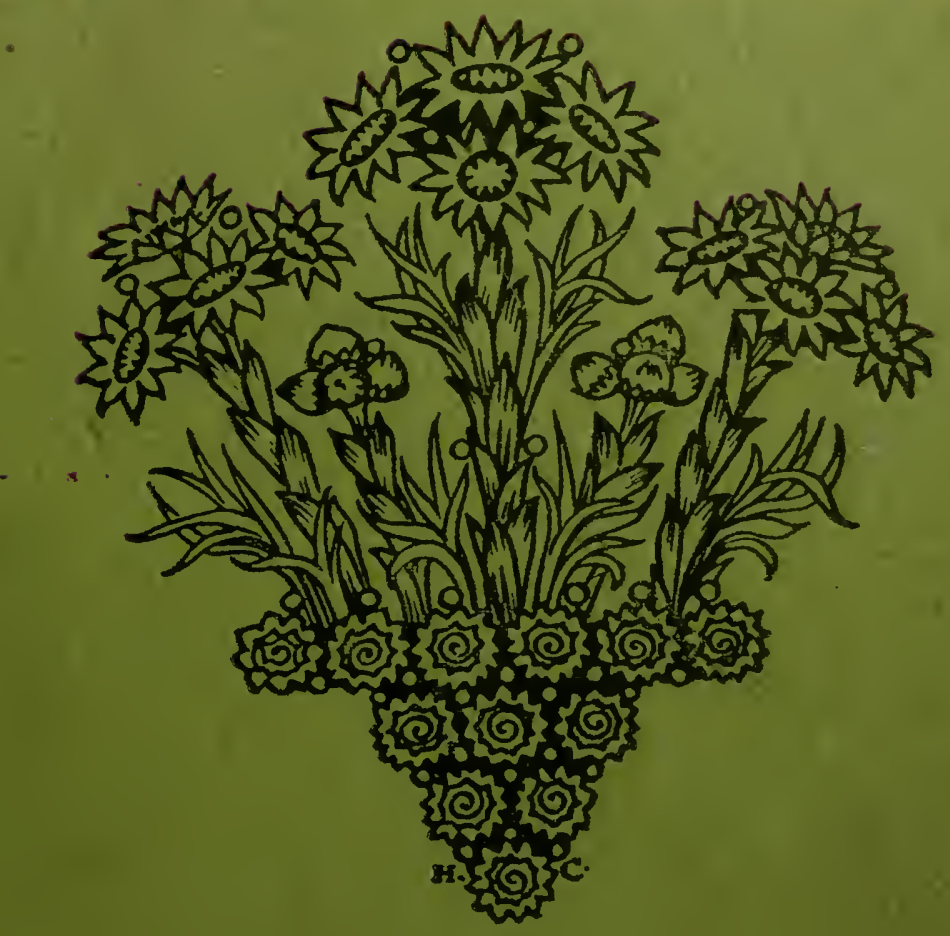

BX SOMERVILLE HASTINGS 


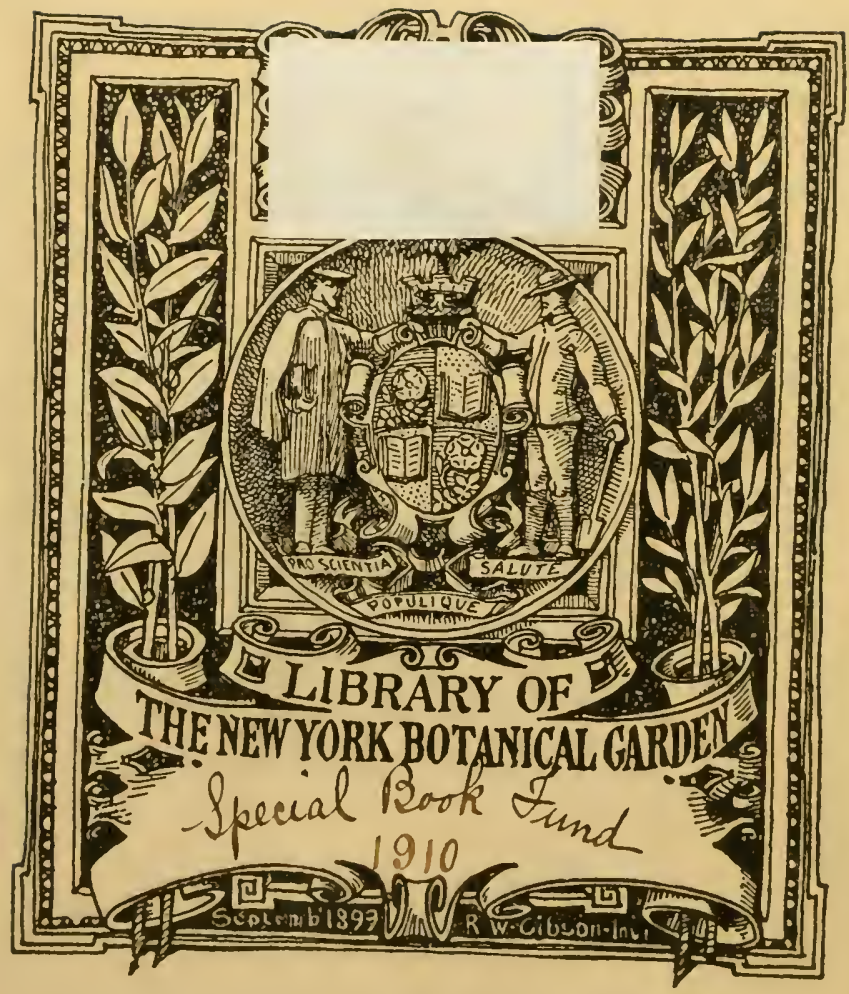








\section{SUMMER FLOWERS OF THE HIGH ALPS}





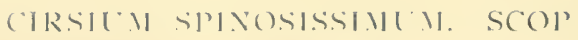

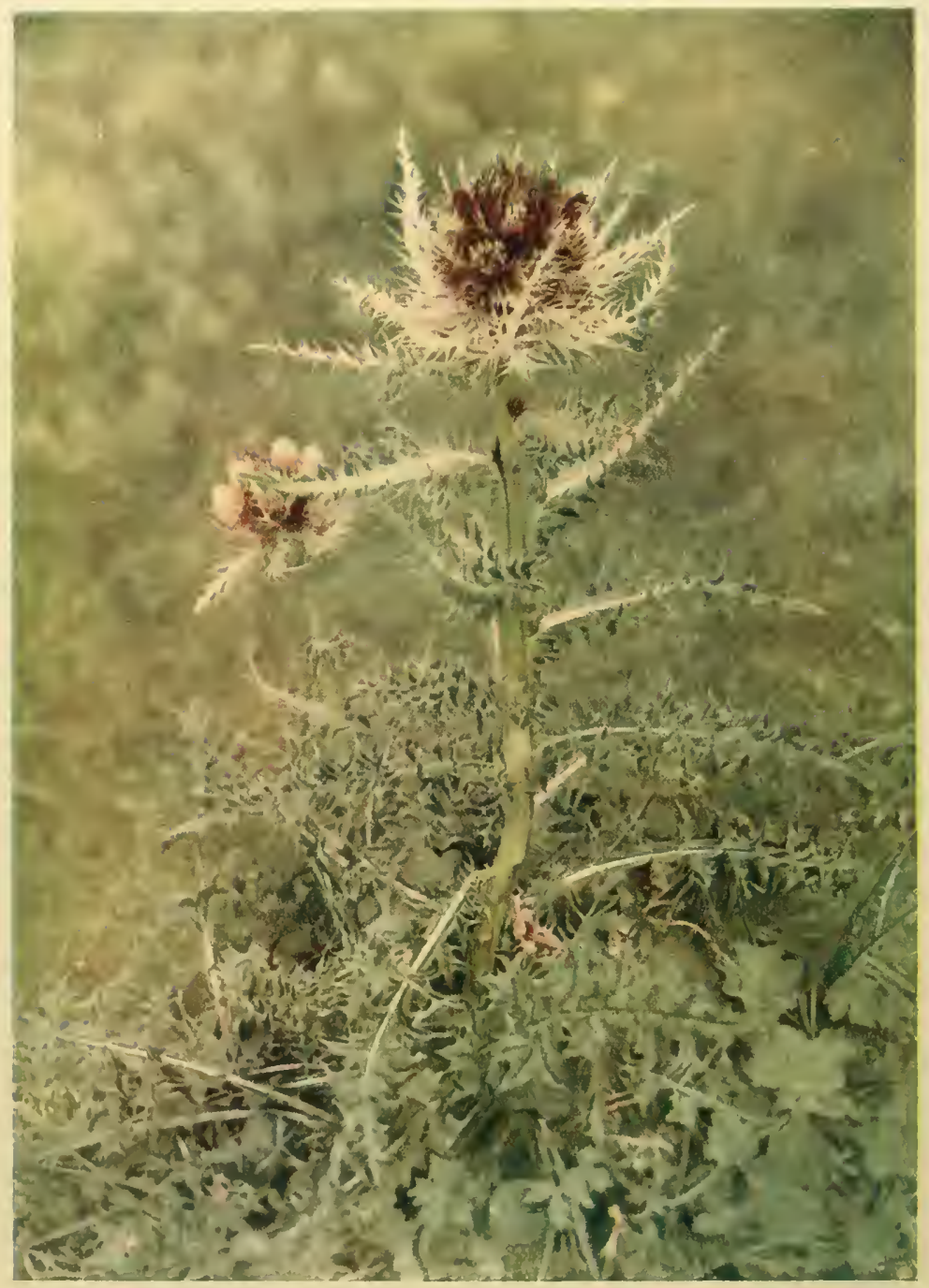

'The Sping fulle's Thistle. lec chardon k plus épineaux. Stachlige Kratzdistel. 


\section{SUMMER FLOWERS}

OF

THE HIGH ALPS

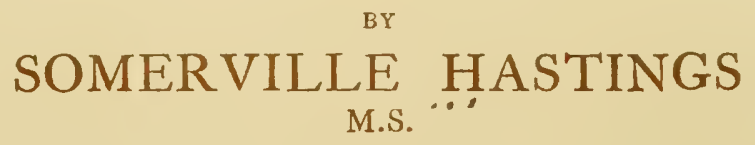

AUTHOR OF "ALPINE PLANTS AT home," SERIES I. AND II.

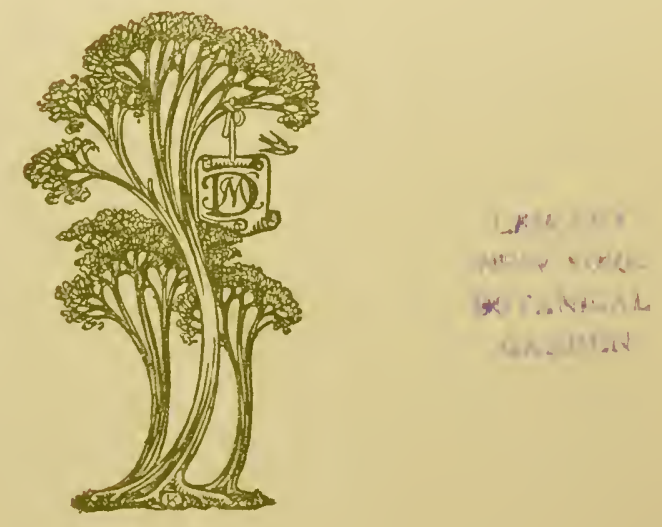

ILLUSTRATED BY REPRODUCTIONS

FROM DIRECT COLOUR PHOTOGRAPHS

BY THE AUTHOR

LONDON: J. M. DENT \& SONS, LTD.

NEW YORK: E. P. DUTTON \& CO. 
.1433 


\section{Preface}

THE coloured plates of Alpine plants, which are the special feature of this book, are all reproduced from colour photographs taken directly from nature. The plants were all photographed exactly as they were found, with two exceptions, in the immediate neighbourhood of Rosenlaui in the Bernese Oberland during the month of July 1909; so that the pictures are true portraits of the flowers "at home."

The Lumière process of colour photography which was used, depends on the action of light on a photographic plate after its passage through various coloured starch grains. The process is entirely beyond the control of the operator, and the exact colours are automatically reproduced. These photographs have in turn been carefully reproduced for this work by the three colour process.

The flowers here photographed were selected as good examples of common and typical species; and, of course, they represent but a very small portion of the rich flora of Switzerland. The present volume is intended as a short introduction to the subject, for the fuller study of which the following works are recommended:-

A. Gremli, "The Flora of Switzerland." Translated by Paitson.

A. W. Bennett, "The Flora of the Alps."
G. Hoffmann, "Alpine Flora." Translated by E. S. Barton. 
L. and C. Schröter, "Coloured Vade-mecum to the Alpine Flora."

C. Schröter, "Das Pflanzenleben der Alpen."

F. E. Hulme, "Familiar Swiss Flowers."

"Hints and Notes for Travellers in the Alps," being the General Introduction to Ball's Alpine Guide.

They have all been freely referred to in the preparation of the accompanying notes.

Wherever possible the common name of each plant in English, French, and German has been given on the corresponding plate. It is hoped that this may be of use to the reader.

In conclusion I would like to thank the publishers for the great trouble they have taken in the preparation of the plates, and Mr Howard Farmer, of the Polytechnic School of Photography, for much valuable advice.

\section{Somerville Hastings.}

New Cavendish Street, W.

April 1910. 


\section{Illustrations}

The Spiny Fuller's Thistle . . . . . Frontispiece FACING PAGE

The Narcissus-Flowered Anemone . . . 2

The Globe Flower a . . . . . 4

The Common Monk's-Hood . . . . 6

The Yellow Wolf's-Bane

The Two-Flowered Violet • . • • • Io

The Long-Spurred Pansy . • . . 12

The Box-Leaved Milkwort . . . . . I4

The CReeping Gypsophila • • • • 16

The Moss Campion or Cushion Pink . $\quad$. $\quad$ in

The Wood Geranium . . . . . 20

The Alpine Clover a . . . . . 22

The Brown Clover . . . . . . 24

The Cold Mountain-Lentil a . • . 26

The Dull-Flowered Sweet Clover or Alpine Sainfoin 28

The White Dryas • • • • • • 30

The Alpine Rose . • . . . . . . 32

Fleischer's Willow-Herb • • • • 34

The Mountain House-Leek . . . . 36

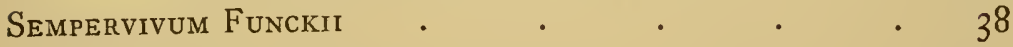

The Evergreen Saxifrage . • • . 40

The Large Astrantia • • • • • 42 
The Alpine Starwort or Alpine Aster

The Cat's-Foot, Mountain Everlasting or Mountain Cudweed

The Arnica

The Round-Headed Rampion

The Bearded Bell-Flower or Campanula

The Dwarf Hair-Bell or Bell-Flower .

The Hairy-Leaved Alpenrose

The Lesser Winter-Green

The Stemless Gentian .

The Short-Leaved Gentian

The Alpine Toad-Flax

The Alpine Balsam

The Leafy Lousewort

The Yellow Auricula

The Marsh Orchis

The Lady's Slipper

The White Veratrum 


\section{Introduction}

No one can visit Switzerland for the first time without being struck with the singular beauty of its wild flowers. In the early summer the whole country from the lowland meadows right up to the snowline is ablaze with beauty. Probably in no other part of the world are the forms of the flowers more pleasing and their colours more brilliant. Hence it is that almost everyone who visits the Alps, however little interest he may take in the wild flowers of his own home, desires to know something of the wonderful new forms that everywhere meet his gaze. Here the charm of novelty also comes in, for at least half the flowers met with in the Alps are absent from the plains, and many of the species that occur in both situations have, as we shall see later, acquired such different characters at high altitudes as to be with difficulty at first sight recognised. Those who would see Switzerland in all its beauty, and as far as its floral treasures are concerned, at its best, must visit it in early June before the hay is cut. Otherwise they will miss the glory of the unmown meadows, and although many of the spring flowers, like the Crocuses and Primulas (Plate 35), may still be found in small quantities at high altitudes even in July, the striking effect of the large masses of these flowers will be entirely wanting.

If we travel to Switzerland by the ordinary tourist route, across Germany or France, and then ascend the mountain ix 
peaks, we shall, in the first part of our journey, notice but few differences in the regetation from that to which we are accustomed. The wild flowers of France and Germany are very like those of the South of England and, except that perhaps the yellow Fuller's Thistle (Circium oloraceum) may be seen in damp places near the railway, very little of botanical interest will be observed until the customs are passed and Switzerland itself is reached. Even here the traveller may be for a time a little disappointed. The first unfamiliar plant to be noticed will very likely be the Redberried Elder (Sambucus racemosa). A little later, in some shady wood, the tall feathery Spiræa (Spirca Aruncus), or the beautiful little May-Lily (Maianthemum bifolium), may be seen. Or a glimpse of the white-flowered Rampion (Phyteuma spicatum) or the Alpine Honeysuckle (Lonicera alpigena), with its twin red berries, may be had in passing. But not until the mountains themselves are reached will the tourist discover that he has entered into an entirely new plant world.

The main factor which determines the character of the flora of any given region in the Alps is its altitude. But we must not forget that there are other things to be considered beside the absolute height above the sea level, and the local conditions of exposure to the sun and protection from the cold winds are quite important factors. Generally speaking, it may be said that the climate is a good deal milder on the southern slopes of the Alps than in the north. Olives can 
be grown in some of the lower mountain regions of the south, and with them are found many of the plants of Southern Europe and the Mediterranean region which are never seen in places of the same altitude on the northern slopes. It is exceedingly probable that most of the lower parts of the Alps were originally covered to a large extent by forest trees. The oak, ash, and beech still flourish in many parts, although much of the original forest has been removed long ago, and used for building purposes or as fuel, and large areas have been thus cleared for meadow and pasture land. In many districts the spruce and the pine appear to be usurping the place of the other forest trees mainly because the young plants are less eagerly devoured by browsing animals, especially the goats. Below 4000 feet on the northern'slopes and 5000 feet or a little over on the south side of the Alps may be described as the REGION of FOREST TREES, and above this level the ordinary deciduous trees become dwarfed and scarce. That this altitude corresponds fairly well with a transition to a colder climate is seen by the change in the character of the herbaceous plants also. For the next 2000 feet we have the subalpine REGION covered mainly by Coniferous trees. Here are vast forests, particularly of Spruce (Picea excelsa) and Silver Fir (Abies pectinata). The former is the familiar "Christmas tree," which grows to a great height on the mountain sides, its lower branches festooned with grey lichens. Besides these trees the Larch (Larix Europæa) on primary rock, and 
the Scotch Fir (Pinus sylvestris) and the Arolla (Pinus Cembra) are also to be seen.

Above 6000 feet in the north and 7000 in the south the Conifers become dwarfed and stunted, and gradually disappear to give place to the Alpine region. Sometimes as we look along a valley the line of transition is seen to be abrupt and straight, at other times irregular and undulating. Bushes of Alpenrose, Juniper, and Alpine Willow extend upward to the Alpine region, but larger trees are entirely absent. Here are found in profusion the greater number of the plants and flowers peculiar to the Alps. Many of the species may of course be found in sheltered or secluded spots at much lower levels, but here are to be seen in abundance the bright-coloured Saxifrages, Gentians, Anemones, and Pansies, which make the Alps their particular home. Here are the alps or upland pasture grounds of the Swiss, and here are situated the châlets or summer homes of Swiss herdsmen. In June or July, when the pasture is becoming scarce in the valleys and when all the snow is melted on the mountain slopes, the native farmer packs a large copper caldron and whatever else he may require for making cheese into his bullock waggon, and accompanied by his cattle, and often by his family as well, treks upward. The "alps" may be two or three days' journey from his home, so that he must take with him all that he will probably require for his two or three months' stay.

The Alpine region extends from the upper tree limit to xii 
the snowline, which may be taken as somewhere between 8000 and 9000 feet. Some of the most charming and brightly coloured of Alpine plants like Eritricbium nanum and the Cushion pinks (Plate 9) are to be found just below the snowline. Even above this level flowering plants may be met with, for even at the highest altitudes bare rock is to be found from which the snow has been blown by the wind or melted by the sun, or where the slope is too great for more than a very thin covering to remain lodged. The Glacier Crowfoot (Ranunculus glacialis), a pink-flowered buttercup, has for example been found within a short distance of the summit of the Finsteraarhorn, the highest peak in the Bernese Oberland.

Just over two thousand different species of flowering plants are to be found in Switzerland, and a little over half of these are exclusively Alpine. In contrasting the flowers of the Alps with those of our own country, it may be first of all well to consider what we have that Switzerland has not. Of course our seashore plants will be mainly absent, but strange to say a few species of Thrift are here and there found, and the yellow Horned Sea-poppy (Glaucium luteum) even grows in the neighbourhood of Lake Neuchâtel. We are so used to the bluebells of our woods, the purple heather of our heaths, and the yellow gorse of our commons, that we hardly realise how glorious they are. In Switzerland the gorse is very rare, the bluebells are not found at all, and the bell-heathers are absent though the ling is found 
everywhere. Even the purple foxglove is replaced by a yellow variety. These facts should be borne in mind, lest a too unfavourable comparison be made with our own rich flora.

But the flowers of the mountains are truly wonderful, and it is their abundance as well as their bright colours that make them so striking. At the same time, it must be remembered that though so numerous neither the flowers themselves nor the plants that bear them are really larger than their lowland relatives. Indeed, in spite of their bright conspicuous flowers, the plants that grow at the higher altitudes are generally stunted and dwarfed. Most of the peculiarities of Alpine plants, which we will now enumerate, are to be accounted for by the conditions under which they live. That this is really so is shown by the fact that "within the bounds of what must unquestionably be regarded as a single species, individuals change in character as we ascend to higher altitudes, the leaves become more hairy and more fleshy, and the flowers brighter and larger." Even more direct evidence of this is to be obtained by cultivating Alpine plants at lower levels and lowland plants at high altitudes. Not a few of the plants of the mountains when grown in our gardens at home change in character very considerably. They tend to elongate so that their leaves are separated by longer intervals of stem, and their hairy characters very largely disappear. The Bearded Bell-flower (Plate 26) may lose its bearded character, and xiv 
the familiar Edelweiss may, in some cases, develop smooth green leaves almost as hairless as those of an ordinary plant. Conversely, we have the observations of Professor Bonnier, who cultivated the plants of the lowlands at high altitudes in the Alps and Pyrenees. Where the plants were able to grow at all they became, in most cases, stunted and dwarfed. The Jerusalem Artichoke, for example, which forms a tall leafy stem like a sunflower in the plains, became a short stumpy plant with leaves arranged in a rosette at its base. Generally speaking, the plants developed a better marked underground stem, and thicker, darker green leaves than the same species grown under more ordinary conditions.

One of the principal characteristics of Alpine plants is the extensive development of the rootstock and underground stem. This is required to protect them against the strong winds, and to extract as large a supply of water and nourishment as possible from the frequently scanty soil. But there is another consideration of at any rate equal importance. During at least half of the year owing to the white coverlet of snow, all activity in the Alpine plant world ceases so that the production of flowers and seeds, indeed all the vital processes of the plants must be crowded into the few months when the ground is clear. Crocuses and Snowbells and other plants are found blooming at the very edge of the snow, therefore everything must be ready for immediate flower production directly the snow 
melts. For this to take place a reserve store of nourishment is essential, and accordingly Alpine plants are furnished with thick underground stems and fleshy roots where the food substances can be stored.

It is further interesting to note that the number of plants that go through their life cycle in a single year and then die off (annuals as they are called), is in the Alps comparatively small, for most of the plants persist from year to year. Kerner states that while only 44 per cent. of the plants on the Danube plains are perennials, there are as many as 96 per cent. in the Alps. That this has something to do with the conditions under which the plants grow is seen by the fact that the annual meadow-grass (Poa annua) becomes perennial in the Alps. Annuals persist through the winter season, only in the form of seed, so that a single wet summer such as the last (1909), by interfering with the ripening of the seeds, might threaten with extinction an entire species. Annuals have but little food stored up for a sudden outburst of activity on the approach of spring, nor can the tiny root of a budding seedling obtain from the soil all that is necessary for the rapid production of flowers and seeds. Moreover, as we shall see immediately, the production of seeds is in most plants very largely dependent on the presence of insect visitors, and without them either less fertile seeds or no seeds at all are in most cases formed. Insects are said to be less numerous in the Alps than in the plains, and thus the assumption of a perennial character xvi 
makes the existence of the plant less dependent on external conditions.

Another point which has already been referred to is the low stature and stunted character of so many Alpine plants. Undoubtedly there are marked exceptions, such as the tall Gentians; but, generally speaking, it must be admitted that mountain plants are short stemmed and dwarfed, the vegetative part of the plant being often merely represented by a wreath of leaves. This is also very largely the result of the peculiar conditions of plant-life at high altitudes. The bright sunlight by day and intense cold at night have both a retarding effect on the growth of the stem. As regards light, the converse result is well seen in the long, lanky shoots of a potato growing in a dark cellar. But there is also another factor of some importance. The green leaves of plants are constantly giving out as watery vapour the fluid which has been absorbed by the roots. The decreased atmospheric pressure at high altitudes, the general dryness of the air, and the bright sunlight by day all unite to accelerate this process. During the day the ground is warmed even to a larger extent than the air, and thus the absorbtion of water by the roots is correspondingly hastened. During the night the intense radiation rapidly cools down the soil on which the plant grows, but the surrounding air is not cooled to anything like the same extent. The result is that the absorption of fluid by the roots is diminished in a much larger degree than the effusion of watery vapour from the leaves, and the plant xvii 
is in imminent danger of being dried up. To this danger the plants of high altitudes respond in various ways. In the first place, their stunted character not only diminishes the area of leaf surface for the exhalation of watery vapour and protects them to some extent from strong winds, but it also places them in the lowest stratum of air which is most likely to assume the temperature of the soil. The felted, cushion-like habit (Plate 9) of so many Alpine plants, and the rosette-like arrangement of their leaves (Plate 19), are also of advantage to the plants by exposing less leaf surface directly to the air. The succulent leaves of plants like the house-leeks (Plates 18 and 19), and the hairy covering of the Cat's-foot (Plate 23), Edelweiss, and others, seem also designed to counteract the tendency to too rapid desiccation, and the tough leathery character of many leaves (Plate 7), and the thickened cuticle of others (Plate 30), are clearly of like value. The relatively increased thickness of the leaves of many Alpine plants is also, no doubt, due to the intensity of the sunlight, for direct experiments have shown that increased illumination has this effect. Their usual dark green colour is thought to result from an excess of the green pigment by which plants are able to extract the carbon required for their growth from the air. The rarefaction of the air and shortness of the season of growth at high altitudes, as well as the low stature of most Alpine plants, make it essential that assimilation should take place as rapidly as possible when conditions are favourable for it. xviii 
But it is in connection with their flowers that the wonderful adaptation of Alpine plants to their surroundings is perhaps best seen. The plants of high altitudes generally bear more numerous and more brightly coloured flowers than do their relatives of the plains. The low stature of the plants that bear them gives rise to the impression that the flowers of the Alps are also larger than those of lowland districts, but though undoubtedly more numerous and more crowded together they are of about the same size as those of other nearly related species. The colours of the flowers are, however, undoubtedly deeper and more intense. If we examine specimens of the same kind of flower, for instance the Forget-me-not or Eyebright, that have been found growing at different altitudes, we shall be struck with the deeper tints of the flowers from the higher regions. That this character has something to do with the conditions of life in Alpine districts is shown by the disappointment that we sometimes feel at the diminished brilliancy of the flowers of Alpine plants when grown in our gardens at home. The flowers of the Alps are also, as a rule, of a more highly organised type than those of the plains, and corresponding with this increase in complexity is a relative increase in the number of pink and blue flowers, and a diminution in that of the yellow and white. Alpine plants, too, seem to produce more honey than do the corresponding plants in the plains; at any rate, the yield of honey from bee-hives is greater, and Bonnier has shown that the secretion of honey by xix 
flowers of the same kind increases with the altitude, and that in some cases there is a corresponding increase in the intensity of the scent of the flower.

While many of the characteristics of Alpine flowers are to be explained as a direct result of the conditions of life at high altitudes, it is probable that the process of natural selection has also had a good deal to do with their production. One of the principal objects of the life of a flowering plant is to produce seeds. It has been shown that, generally speaking, more numerous and healthier seeds are produced when the seed-producing apparatus of a flower is fertilised by pollen from the stamens of a flower of a different plant. Hence arrangements have to be made by plants for the conveyance of their pollen from flower to flower. This is sometimes effected by the wind, but much pollen is lost, so that this is manifestly a very wasteful method. Plants have therefore adopted the more economical plan of getting insect visitors to do this carrying business for them. The bright colours and sweet scents are to attract insects to the flower, and honey is provided for their entertainment there. It is generally believed that the total number of insect visitors in the Alps is less than in the plains, and therefore the competition for their services being more severe, greater attractions in the form of brighter coloured flowers and more abundant honey have to be provided for them. But, unfortunately, the direct observations of $\mathrm{H}$. Müller do not confirm this view. There can be 
no question, however, that the relative proportion of the several varieties of insects in the Alps is very different from that in the plains. There are comparatively few flies, bees, and wasps, but numerous humble-bees, butterflies, and moths in the mountain regions. These insects have longer tongues and prefer to visit flowers of a more complicated structure, where the honey cannot be reached by their shorter tongued relatives. Flowers of this sort with less easily obtained honey are more often of a red or blue or pink colour, and more rarely of a yellow tint. Not a few Alpine flowers like the Aconites (Plates 3 and 4) are entirely dependent on humble-bees for their fertilisation, and an even larger number, such as the Long-Spurred Pansy (Plate 5), and several of the Gentians are exclusively visited by butterflies and moths. Müller even goes so far as to suggest that not a few of the Alpine flowers, especially those of a pale crimson colour and with a clove-like smell, such as the Pinks (Plate 9), have been evolved in the Alps under the influence of butterflies and moths. In spite of this it is curious to note that the number of flowers that are habitually self-fertilised is greater in the Alps than in the plains. But when it is explained that these are for the most part of the same type of flower that is pollinated by flies, bees, and wasps in lowland districts the apparent anomaly becomes clear.

The question of the origin of the Alpine flora is a subject upon which botanists are by no means completely $\mathrm{xxi}$ 
agreed at the present time. A large number of the thousand different plants that are found in the high Alps reappear in distant mountains and the Arctic regions, though absent in the intervening country. Thus the late John Ball calculated that I7 per cent. of the Alpine species were met with in the Arctic regions, and 25 per cent. in the Altai Mountains of Northern Asia. That this is not due to the conveyance of seeds from place to place by the agency of wind or birds is shown by the fact that the resemblance of the plants of different mountain chains to one another is in no way proportional to their geographical proximity, even when their climate is similar. The true explanation is probably to be sought in the Glacial Period, in which the greater part of Europe was covered by ice, so that the climate of the plains was very similar to that of the high Alps and Arctic regions at the present time. At this period the flora of the extreme north was able to mingle with that of the mountain regions. When the climate of the intervening districts became once more less severe, the competition with the present lowland flora became so keen that the Alpine-Arctic plants retreated to high altitudes or the far north. It may be that the high mountain regions have formed centres for the evolution of new species, as Mr John Ball believed, but there is but little direct evidence for this view.

Nearly every visitor to Switzerland who regards its rich flora in any way worthy of notice is desirous to obtain some permanent record of the pleasing impressions obtained. Either xxii 
the flowers are pressed, or the plants are pulled up with more or less of their roots to be planted in some garden at home, or, as the author would suggest is by far the best method, photographs of the plants are taken. May we here, first of all, protest against the wholesale destruction of Alpine plants that goes on every year by careless visitors. Where a few flowers are required for study or to be preserved by pressing, they may, by all means, be picked. There seems no reason also why a few of the more common or abundant plants should not be dug up with their roots, carefully packed, and taken home, although the Swiss authorities do not permit even this, but it is disgraceful that large nosegays of choice flowers should be gathered for the mere pleasure of watching them wither in the hand, and then thrown away. The Swiss natives, unhappily, set us a very bad example in this respect; but it is fortunate that the Edelweiss and Alpenrose are the only flowers that they at all extensively attack. Many of the more frequented tourist routes have become almost bare of any but the commonest flowers. One has only to ascend to some peak or glacier by two paths, one that is well-trodden, and a second but little used, to see how complete this destruction of wild flowers has been.

Excellent little presses for preserving plants and flowers can be bought in Switzerland. They take up no more room in one's bag than a Baedeker or Bradshaw's Guide, and do the work much more efficiently. Their only disadvantage is that they are generally too small to display any but the xxiii 
tiniest plants completely, and it is really wiser to take out from England a couple of boards with straps and a good supply of blotting paper. The special paper sold for pressing plants is much to be preferred to ordinary white or pink blotting-paper, as the plants tend to stick to it much less. A fair amount will be required, as the plants need frequent changing and the paper must be dried. Specimens should be carefully set out by pressing on them with the finger till they take up the required positions, and stored when dry in some exercise book or between sheets of paper.

The cultivation of Alpine plants in our gardens at home is by no means as easy as might at first be supposed. The climate and conditions of life in Peckham are very different to those at the summit of Pilatus, and unless the thing is done carefully and thoroughly it had better not be attempted at all. The chief difficulty in growing Alpine plants in our climate is not the cold but the excessive moisture of winter, which tends to rot their roots, and from which they are protected in their native home by their snowy covering. Our object should be to reproduce, as far as possible, in our gardens the conditions under which the plants grow in the high Alps. For the rockery a porous stone will be required, such as limestone or sandstone, and it is essential to select a kind that does not crumble with the frost. The partially fused masses of brick, which can be obtained very cheaply as a waste product from brick kilns, when washed over with a mixture of cement and sand do very xxiv 
well. The rocks and stones must be so laid that every bed or pocket in which the plants are to grow is thoroughly well drained, for nothing is so destructive to them as water-logging of the soil. Plants that grow in the clefts of rocks should be planted in a sloping position, as water is then less liable to collect in the rosettes of leaves. Those that grow in cool, moist, spongy soil are best planted in a mixture of peat moss and earth. It is also important to notice whether the plant which is being cultivated was previously growing on limestone or granitic soil, for it is easy to add a little chalk to the earth if this is required. In planting out one has to be careful not to curl up the roots, and it is wise to sprinkle the plant with water two or three times a day for the first week or so. Alpine plants should never be manured. It should be remembered that mountain plants grow slowly, and though very many species can be successfully cultivated, the Houseleeks and Saxifrages are likely to give the best results with a minimum of trouble.

It is impossible in such a book as this to give more than a few general suggestions as to the photography of Alpine plants. One of the chief difficulties with which one has to contend is the wind. When the plant is photographed anywhere near its natural size the smallest stop has to be used to obtain depth of focus, and this greatly increases the duration of the exposure. Many of the colour photographs herein reproduced were given as long as five or ten minutes. When the wind is intermittent it is quite safe to 
give repeated exposures of a few seconds at a time, being careful in removing and replacing the cap not to shake the camera, for the plant is sure to return to exactly the same position after being blown to and fro by the wind. Where tall plants are being taken it is wisest to select a time in the early morning or near sunset, for though the intensity of light is diminished at these times, there is usually but little wind. The writer has found a strip of white calico, some 12 or 15 inches wide, with long knitting needles sewn on to it at intervals, of great value as a wind screen in plant photography. The knitting needles can be pushed into the ground, and the plant surrounded on three sides or completely by such a screen, and thus very largely shaded from the wind. With a little care the screen does not appear in the photograph, and it is easily rolled up and carried from place to place. For near objects the intensity of light in the Alps is only slightly greater than that in England at the same time of day, but it is always wiser to make use of an exposure meter if the best results are desired. By the use of the swing back any plane surface, whatever be its inclination to the vertical, can be easily focussed. This will be found of especial value where a blurred background is desired, and the slight distortion thus obtained, which is so noticeable in architectural subjects, is quite negligible in the case of plant portraits. The deep shadows that are produced when flowers are photographed in bright sunlight are generally best avoided. 


\section{SUMMER FLOWERS OF THE HIGH ALPS}

HERE FOLLOW COLOURED PLATES AND DESCRIPTIONS OF 39 SWISS PLANTS, WITH THEIR NAMES IN LATIN, ENGLISH, FRENCH, AND GERMAN 


\section{The Narcissus-Flowered Anemone (ANEMONE NARCISSIFLORA)}

MANY varieties of Anemone are found in Switzerland. Not only have we the common English Wood Anemone ( $A$. nemorosa) of the early spring, and the much rarer Pasque Flower (A. Pulsatilla) of our downs, but there is also the white or yellow Alpine Anemone ( $A$. alpina), which forms so marked a feature of the Alpine pastures in early summer. Even in July and August, when most of the flowers have faded, the feathery tufts of seeds of the Alpine Anemone are still to be seen as the so-called "Chamois' beards."

The Narcissus-flowered Anemone, here photographed, is a widely distributed plant. It occurs on grassy slopes and in pastures between 4000 and 7000 feet above the sea level, and seems to prefer a limestone soil. The finely divided leaves are well seen in the photograph. Unlike every other species of Anemone found in Switzerland the flower stalk bears not a single flower only but two to eight, or even more, and at the point where the flower stalk divides a green collaret or involucre is seen. The flowers are pure white inside, and their external surfaces are often slightly woolly and tinged with pink, especially in the bud. The seeds have no feathery appendages like those of the Alpine Anemone. The flowers are without honey. They are visited by pollen-collecting insects, and should these fail will become 


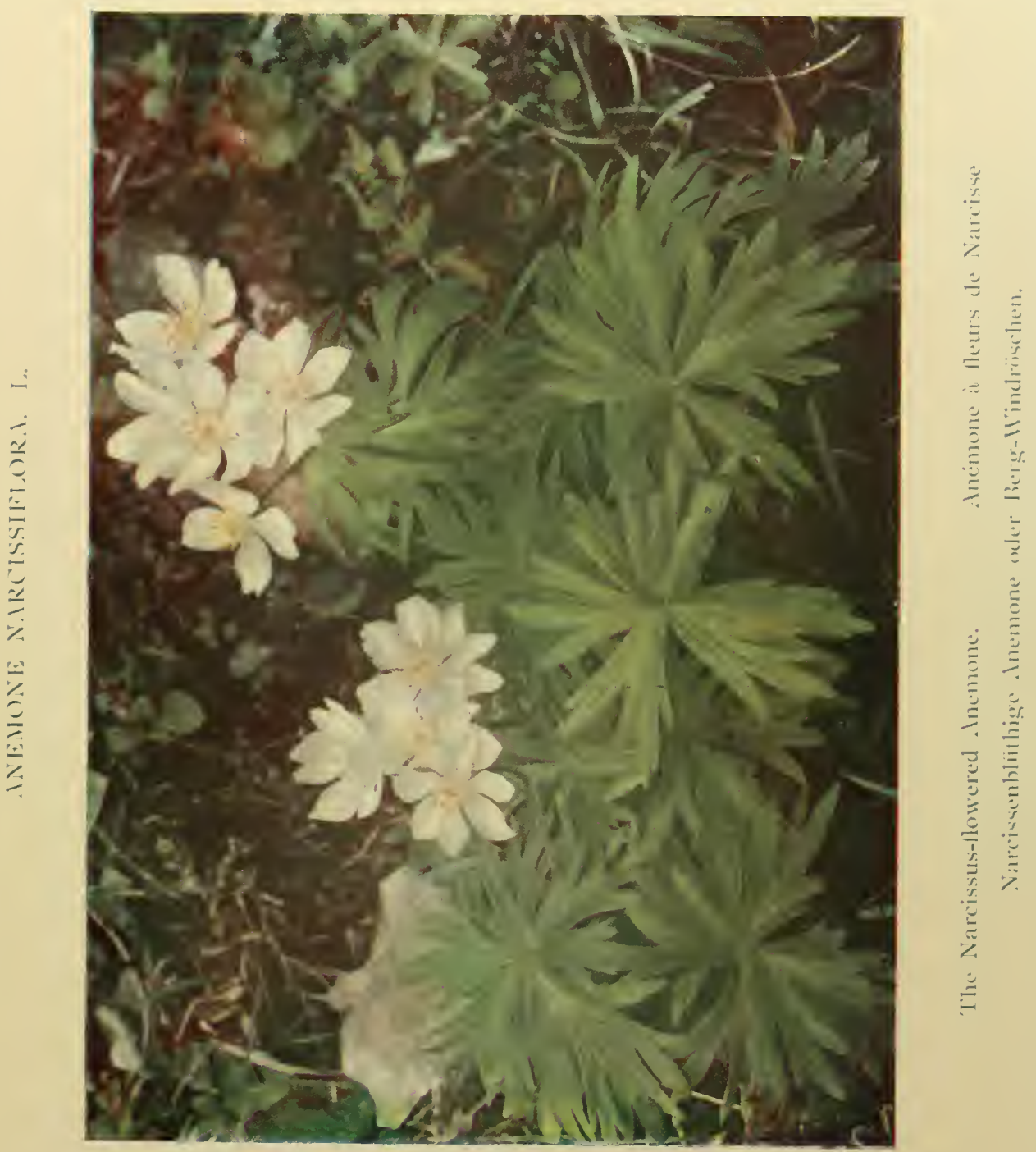



self-fertilised. The plant blooms in May and June, and some flowers may still be found even in July in the highest Alpine pastures. It is met with widely distributed over Central Europe, North America and Northern Asia, but is absent in Scandinavia. On account of the numerous closely allied species which are found in Northern Asia, it is thought that this plant may have originated in that region and then spread east and west to America and Europe respectively. 


\section{The Globe Flower}

(TROLLIUS EUROPAUS)

THis large and stately plant is common in mountain pastures from the lower levels right up to 7000 feet. It has finely divided leaves and bright yellow globe-like flowers, borne on long stalks which are usually unbranched. It is evidently a near relation of the buttercups, but differs from them in the possession of numerous brightly-coloured sepals, which enclose and conceal the much smaller tongue-shaped petals. Although not exclusively Alpine, being found all over Central Europe, in Scandinavia, and the north of England, it has been included in this series because it is sure to be noticed by anyone visiting Switzerland for the first time.

It flowers in May, June, and July, and flourishes best in damp places. A much smaller form, bearing only a single flower, is found exclusively on high mountains (var. bumilis). It should probably be regarded merely as a variety and not as a distinct species.

The Globe Flower, the Anemones, and the two species of Aconitum illustrated in the two following plates are all examples of the buttercup order, the Ranunculacer. The common yellow buttercup so abundantly found in Alpine meadows is Ranunculus montanus. This species very closely resembles the ordinary upright buttercup of our English fields (Ranunculus acris), which it replaces in the Alps, 
TROLLIL'S ELROI'EL'S. I.

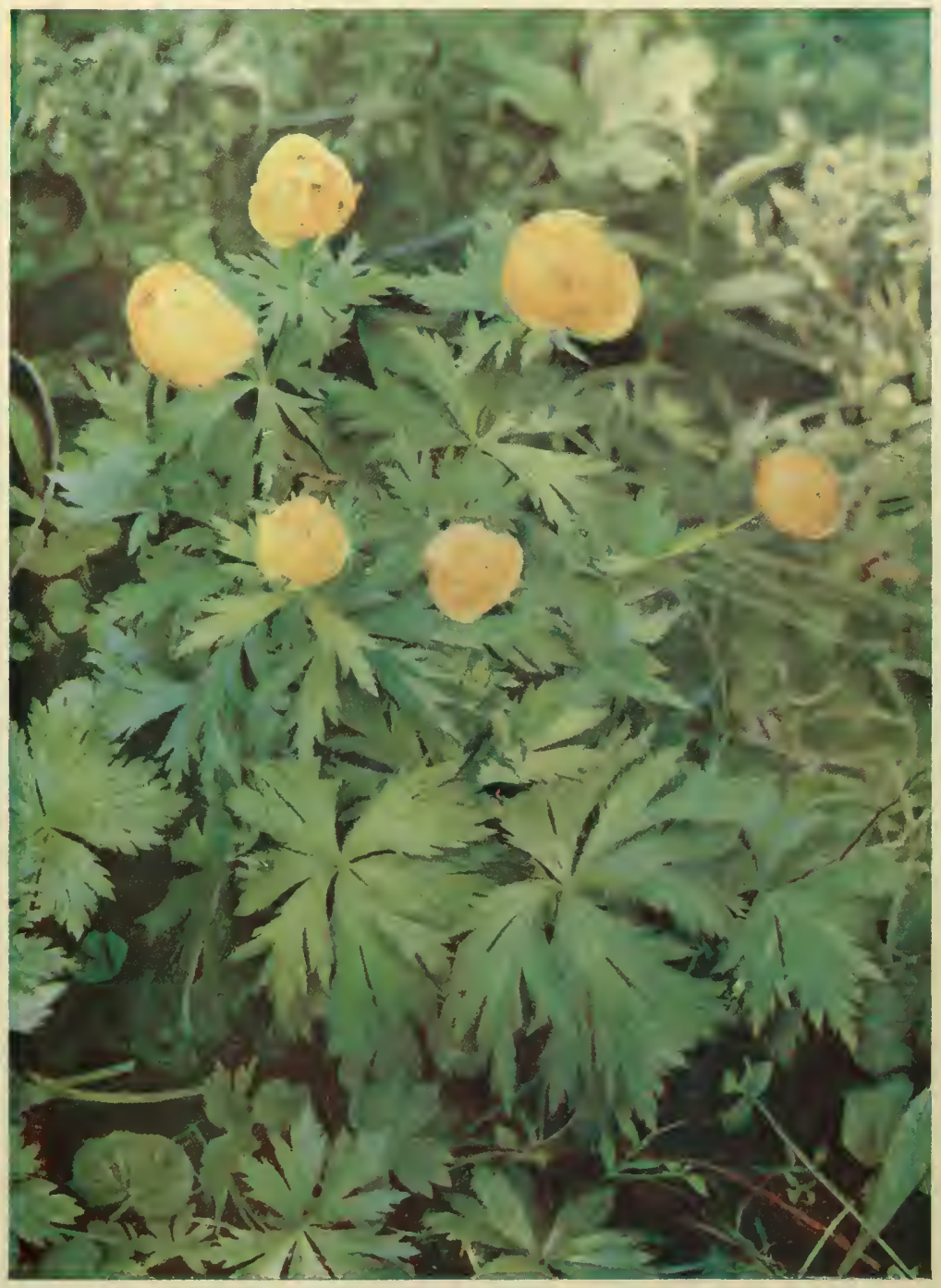

The Gilobe flower. Trolle d'liurope ou Boule d'(Or. Echte ofer Luropiaista Trollblume. 

but differs from it in the possession of a solid (not hollow) stem and a hairy disc beneath the seeds. It is a somewhat smaller plant, with less numerous-generally only two or three-flowers. 


\section{The Common Monk's-Hood (ACONITUM NAPELLUS)}

Several species of Aconitum are met with in Switzerland. They have all bright-coloured flowers, especially adapted for fertilisation by humble-bees. It is only where there are humble-bees to convey the pollen from flower to flower that seeds can mature, so that where these insects do not exist the Aconites cannot spread. The five sepals of the Aconite flowers are coloured for attractive purposes, the highest being especially large and helmet-shaped. Protected by this are the representatives of the petals, so modified and reduced that they no longer have any attractive function, and are only of use to the plant by producing honey. They form a couple of nectaries on long stalks inside the helmet-shaped sepal.

The Common Monk's-Hood is found in rich moist meadows between 3000 and 7000 feet. It seems to be especially common in the neighbourhood of Alpine dairies and cow houses. It flowers in June and July, and is very poisonous. From the conical root, resembling that of horseradish, the preparations of aconite used in medicine are prepared. When applied externally, aconite causes tingling and numbness and may relieve the pain of neuralgia. Internally, it depresses the action of the heart and lowers the temperature of the body. Homeopathists still use it for this purpose, but in doses so small as to have no 
ICONITLM NIPEIILS. 1.

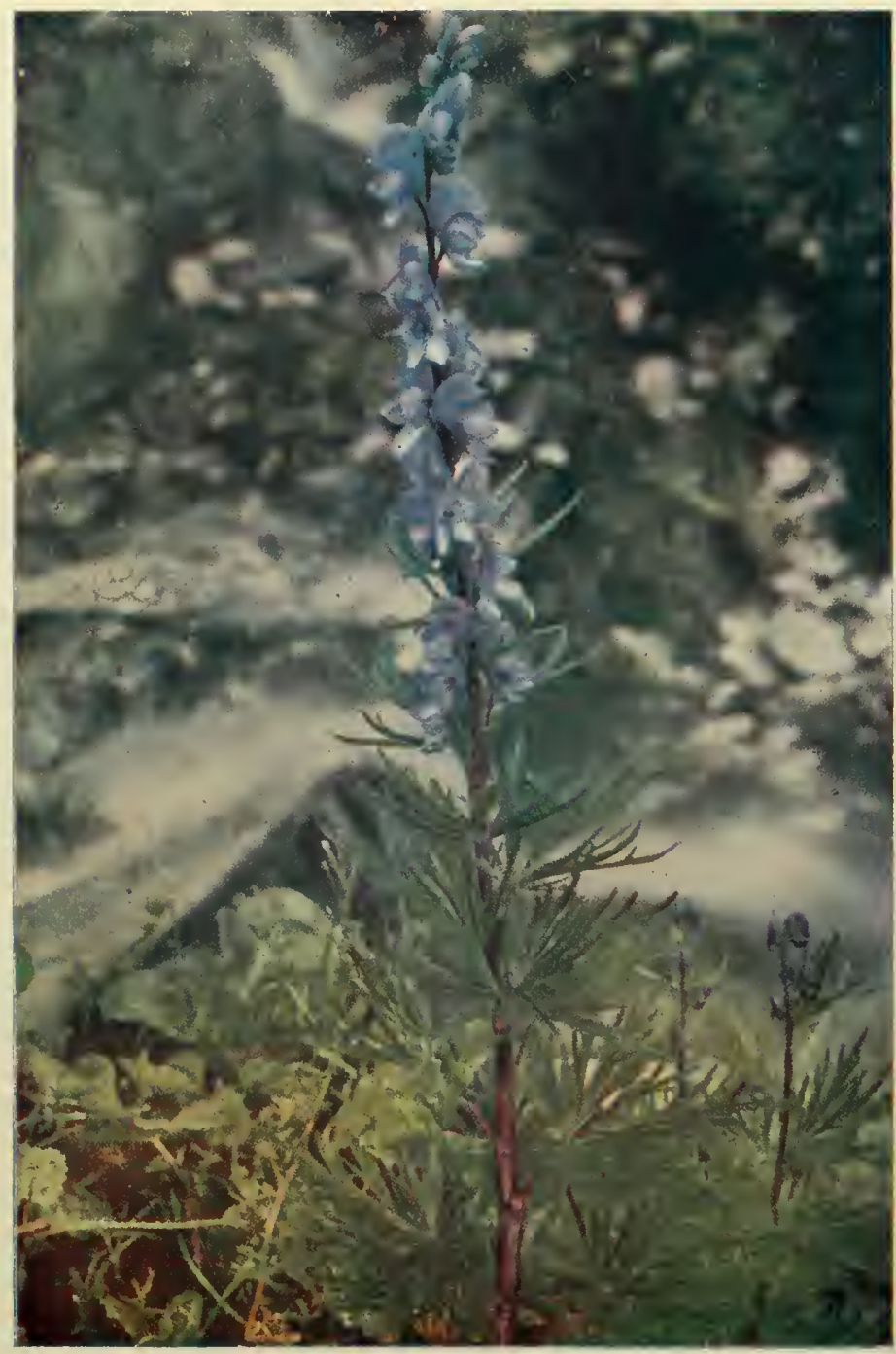

The Common Monk's-Hood. Aconit Napel ou Napel bleu. Riibenwurzliger lïsenhut. 

appreciable action whatever. The single straight flower stalk, closely packed with blossoms, is rarely branched in its upper part, though small branches may be met with below.

The Panicled Monk's-hood (Ac. paniculatum) resembles the above rather closely, but differs from it in the more open arrangement of the flowers on the hairy flower stalk, which is usually branched near the top. The leaves of both plants are finely divided, but the sub-divisions of those of the common Monk's-hood are longer and narrower, more strapshaped in fact, than those of the panicled form. 


\section{The Yellow Wolf's-Bane}

\section{(ACONITUM LYCOCTUM)}

This plant is a species of Aconite, and a close relation of the common Monk's-hood illustrated on the previous page. It is common on the borders of woods and in bushy places between 3000 and 7000 feet above the sea level. In this species, which, like the common Monk's-hood, is visited almost exclusively by humble-bees, the upper helmet-like sepal which conceals the honey is especially long. It is interesting to note that the humble-bees do not, in all cases, obtain the honey in the way intended by the plant. A dark spot is often to be seen near the tip of the helmet where a humble-bee has nibbled through the flower leaf and obtained access to the nectary direct. In this way the designs of the plant for cross fertilisation may be frustrated, for where the honey is obtained in this manner no pollen is carried from flower to flower by the insect visitor. Aconitum Anthora, which is rather like the above, has more finely divided leaves and darker yellow flowers which are much less elongated than those of the Wolf's-bane. The flowers, in fact, closely resemble those of the common Monk's-hood except that they are yellow instead of blue. Both plants are poisonous. 
ACONTTEM LICOTTONLM. I.

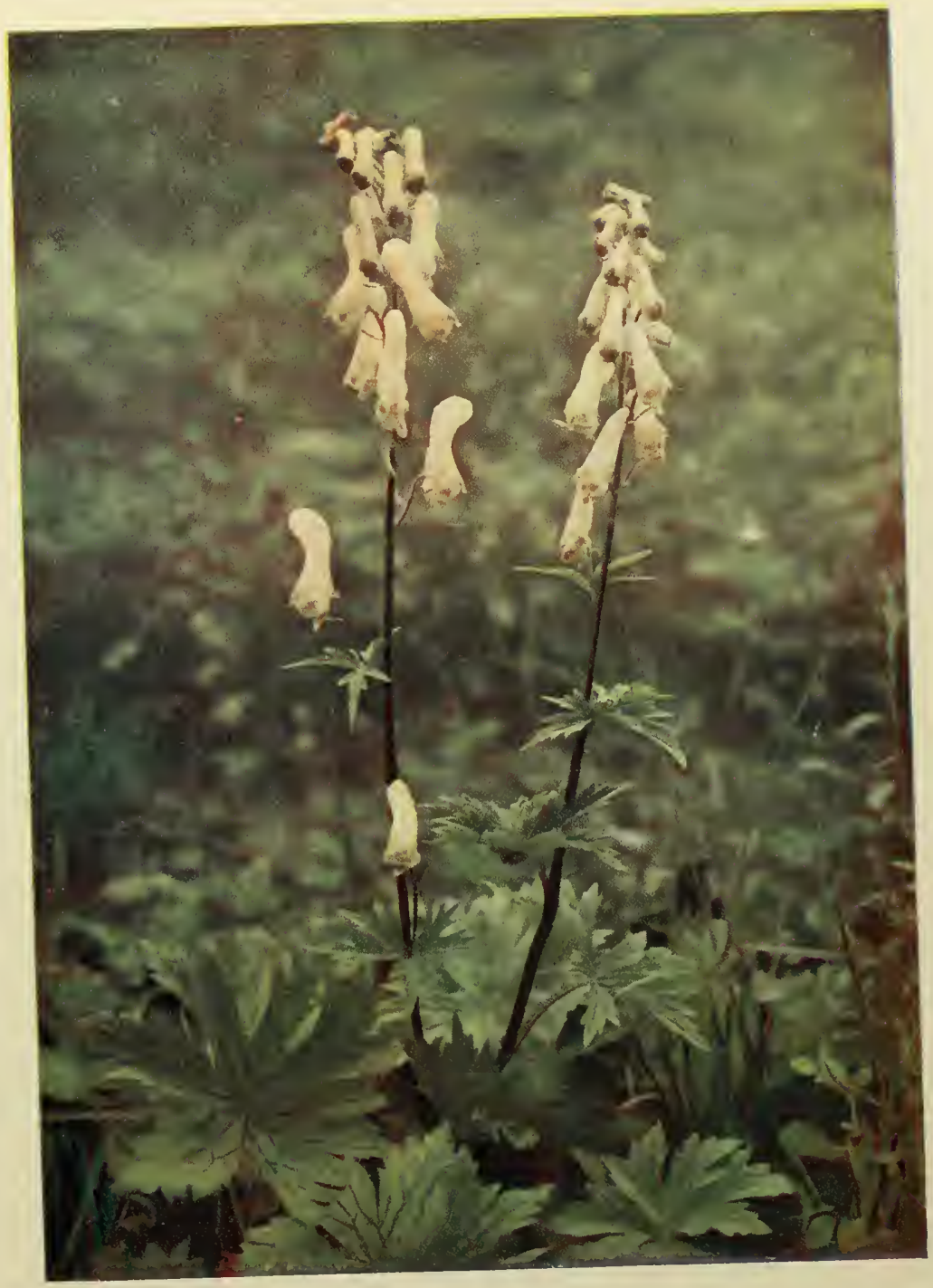

The Yellow Woll's-bane. Aconit Tue-loup ou Citppe de Moine. Wolftiidtender Eisenhut. 




\section{The Two-Flowered Violet (VIOLA BIFLORA)}

This pretty little plant is common in moist shady places between 3000 and 7000 feet all over Switzerland. It is also found in Bohemia, Silesia, the Vosges, and other parts of Central Europe. It flowers from May to August in the clefts of rocks, and amongst the boulders on the banks of streams. It was in just such a place as this that the present photograph was taken. The flowers are bright yellow, streaked with brown, and the dark green leaves are kidneyshaped and entire. Although there are several other violets with yellow flowers to be found in Switzerland, no other species has broad kidney-shaped leaves. The smooth, erect flower stalk, which also bears some leaves, frequently divides into two near the middle, each branch being terminated by a bright yellow flower. This character, which has given to the violet its name, is, however, by no means constant, and flower stems bearing a single or three or more flowers are also often seen. The number of flowers borne by the plant would seem rather to be determined by its size and vigour, which, of course, again depend largely on the conditions under which it grows. 
j

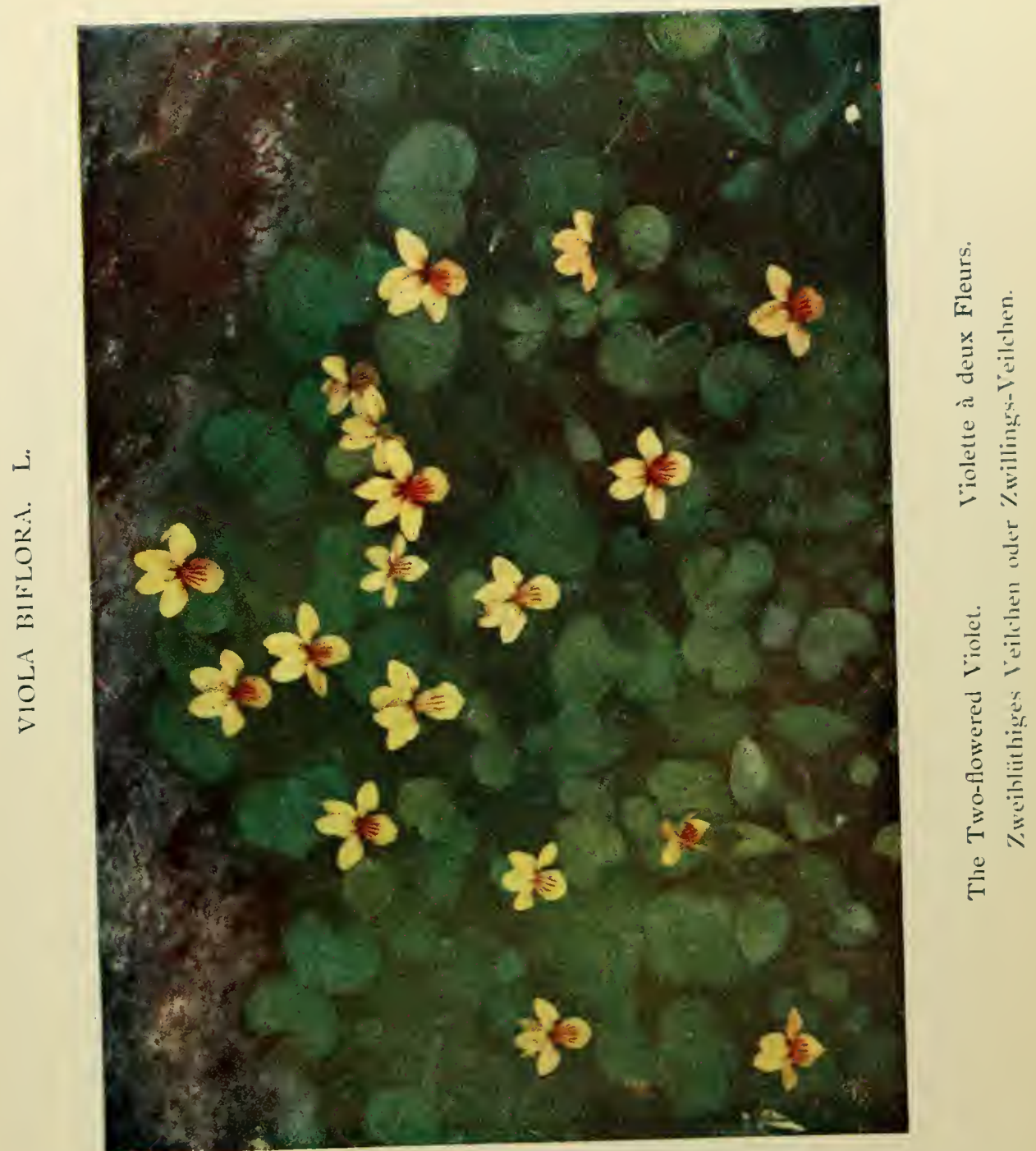






\section{The Long-Spurred Pansy (VIOLA CALCARATA)}

ThE Long-Spurred Pansy flowers in June and July, and is a typical Alpine plant. The high mountain pastures are sometimes literally carpeted with its large purple flowers, all turned towards the sun. It is common on sunny slopes and among rocky debris between 5000 and 9000 feet, and prefers a limestone soil. The underground stem of the plant bears at its extremity a small rosette of leaves, and a short flower stalk terminated by the single large flower. The flower, which has a delicate and sweet scent, is usually of a rich purple colour, much more rarely yellow (var. flava). Sometimes the purple becomes paler and a lavender variety results, and, rarest of all, the flower may be pure white. From the many other violets and pansies which are found in Switzerland, the species we are now considering is recognised by its narrow, notched leaves, by the upward direction of the lateral petals, and especially by the long, narrow spur, which is quite as long as the corolla.

Unlike most of the violets which are fertilised by bees, the Long-Spurred Pansy depends entirely on butterflies for the conveyance of its pollen. The narrow opening to the flower and the long spur, at the bottom of which the honey is concealed, are only suited to insects such as butterflies and moths with relatively long tongues. It is pretty to see 


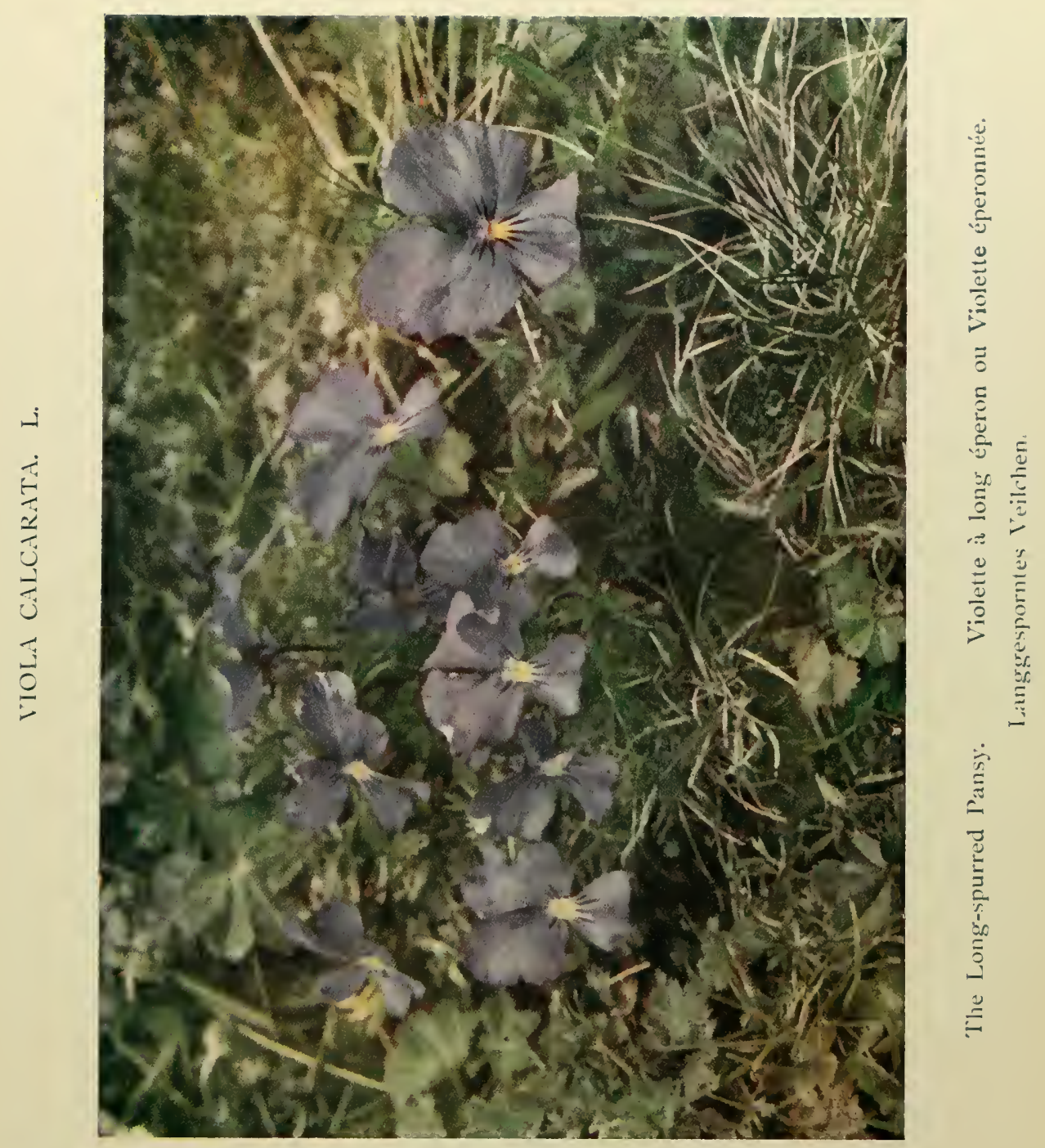



the butterflies flitting from flower to flower, and Müller observed a single insect visit no less than one hundred and ninety-four different blossoms in $6 \frac{3}{4}$ minutes. 


\section{The Box-Leaved Milkwort (POLYGALA CHAMEBUXUS)}

The Box-leaved Milkwort is a shrubby mountain plant with a woody branching stem and leathery evergreen leaves, which resemble those of the common box but are somewhat thicker. The flowers occur singly or in pairs in the axils of the upper leaves. They consist of a boat-shaped corolla of a pale yellow colour, which becomes darker towards the tip, and two wing-like appendages, which look like petals but are really sepals. These are usually white but are sometimes purple red. It is stated that their colour is determined by the soil on which the plant grows and is white or pure slate; on calcareous, slate coloured.

The Box-leaved Milkwort is widely distributed in Switzerland, Germany, and Austria, between 1500 and 7000 feet, and grows on wooded hills and in dry rocky places, where it is often extremely abundant. It flowers from May till the end of August. The plant is quite distinctive and will be readily recognised. Although belonging to the Milkwort tribe it is quite different from all other species, which have red, white or blue, never yellow, flowers and deciduous, not evergreen, leaves.

The Common Milkwort (Polygala rulgaris) of our English downs and heaths is also found in the Alps. It is a small herbaceous plant with a slender stem, perhaps three or four 
POLGALA CHAMEISXLS. L.

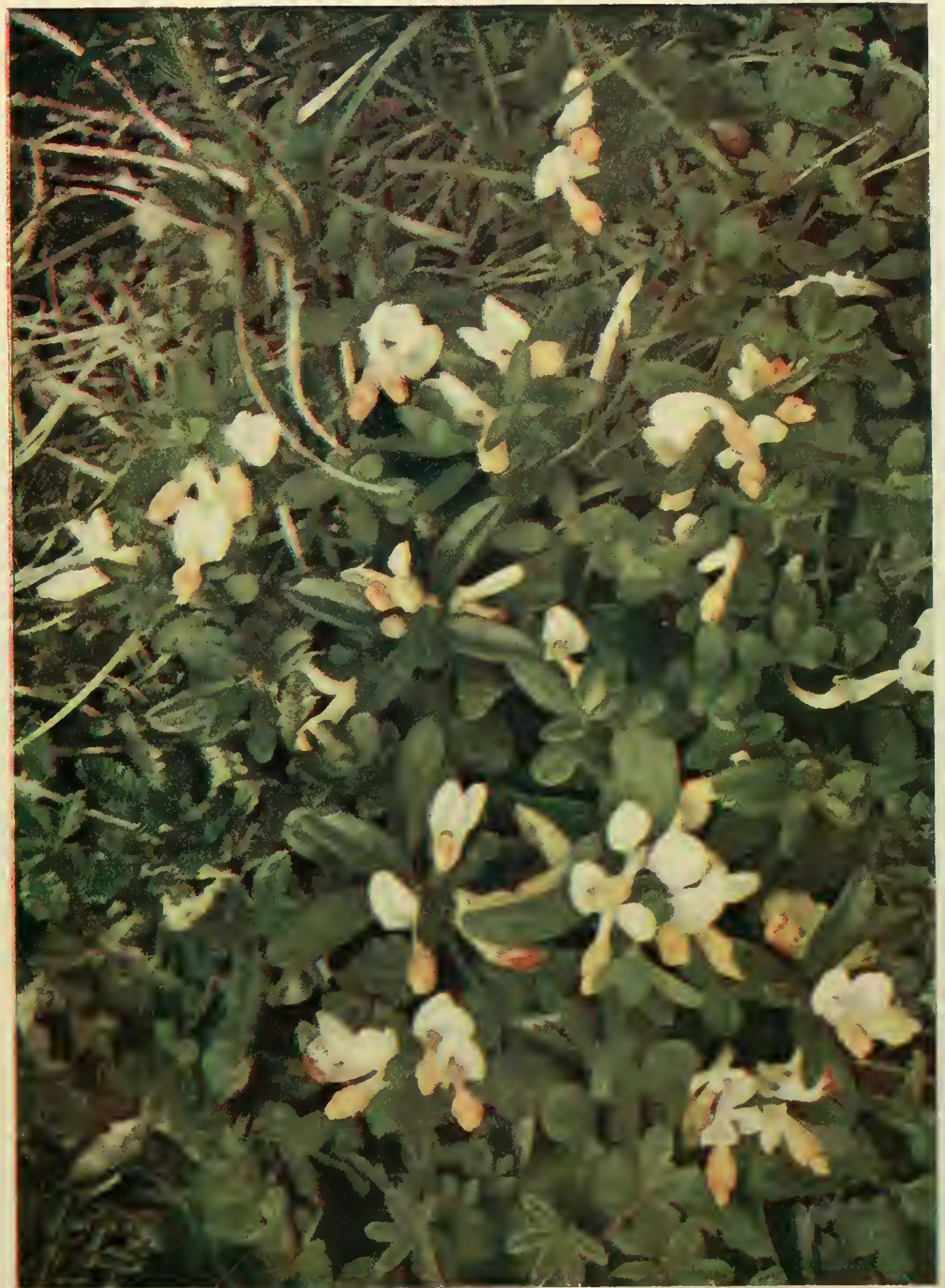

The Box-leaved Milkwort. H'olygala faux-bruis.

Immergriine Kreuzhlume. 

inches long, which is thickly covered with leaves, and terminates in a cluster of pink, blue, or white flowers. Polygala. calcarea, a nearly-related species found only in limestone districts, has sky-blue flowers and leaves for the most part clustered in the form of a rosette at the base of the stem. 


\section{The Creeping Gypsophila (GTPSOPHILA REPENS)}

THE Creeping Gypsophila is a perennial plant with a woody stem, from which branches arise bearing the narrow strap-shaped leaves and pale crowded flowers. It is found in all the limestone regions of the Alps, amongst the rocky boulders beside mountain streams, and in dry torrent beds between 1000 and 7000 feet, and even descends to the plains with certain of the rivers. It is found, for example, near Munich on the banks of the Isar. The plant is also widely distributed in the mountain regions of Central Europe and extends from the Pyrenees to the Carpathians. The flowers, which open in July and August, are white with more or less of a tinge of pink about them, which may be quite marked in certain cases. Together they form what is botanically known as a corymb. The numerous flower stalks branching off from different points of the ascending stem are of such a length that all the flowers are approximately on the same level. In this way they are displayed to the best advantage, so that their insect visitors may find it easy to pass from flower to flower. There are several species of Sandwort and Chickweed to be found in Switzerland that closely resemble the Creeping Gypsophila. Apart from technicalities the chief points to keep in mind in the identification of the plant are the woody creeping stem, the much-branched flower stalks, and the entire absence of hairs. 


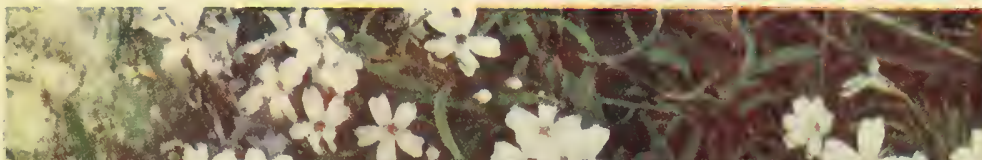

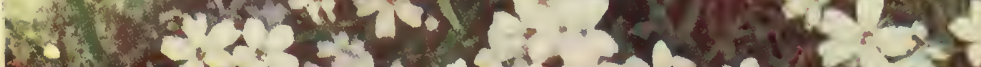

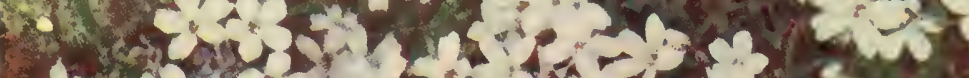

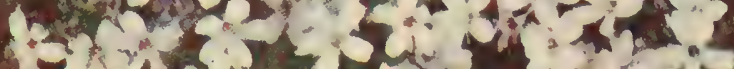

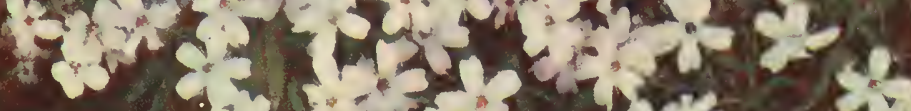

(a)

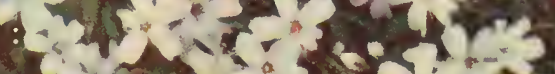

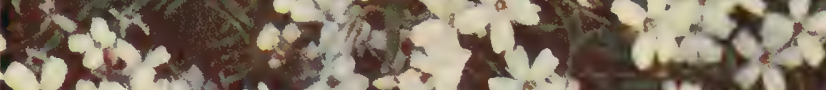

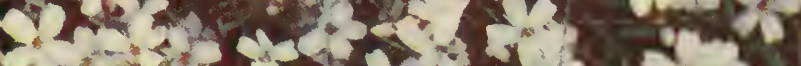

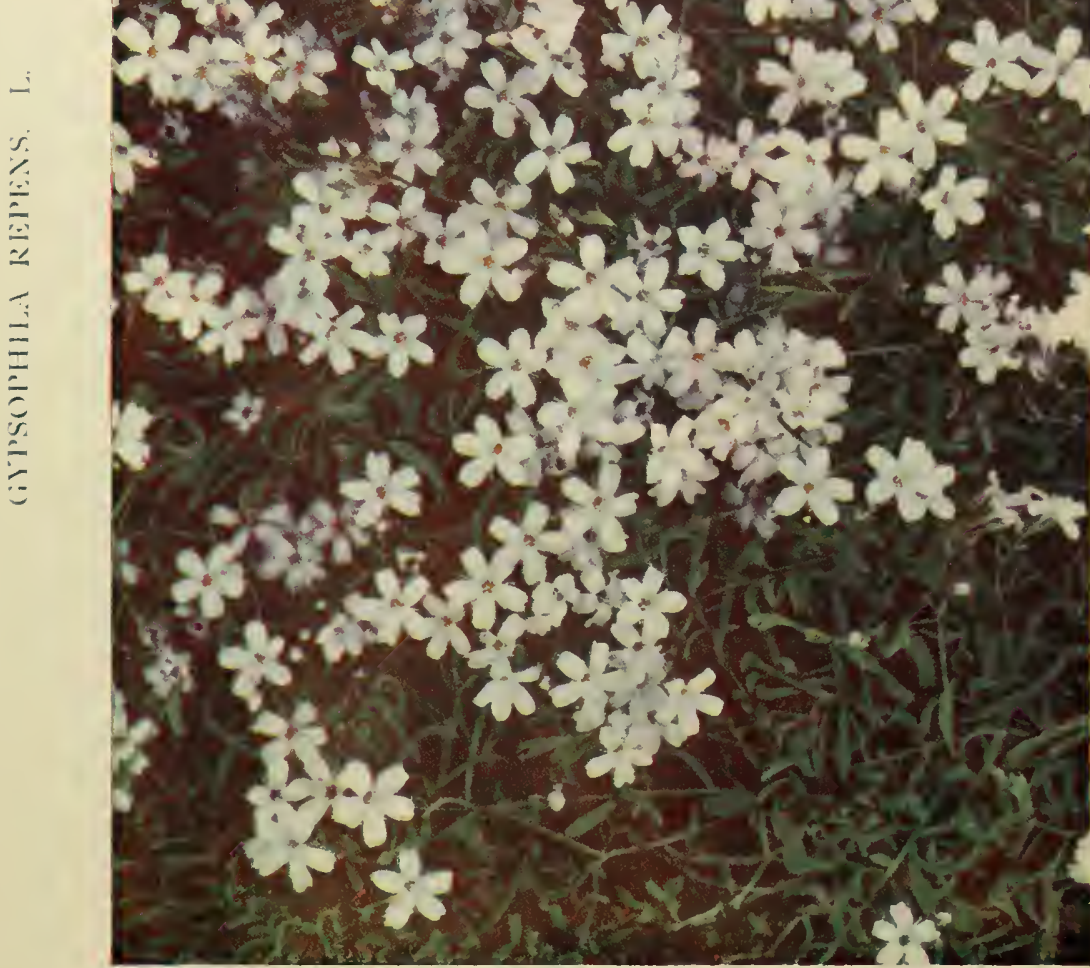





\section{The Moss Campion or Cushion Pink}

(SILENE ACAULIS)

Wherever conditions are unfavourable to plant life, not only on high mountains but also in deserts and by the seashore, the plants that manage to survive frequently respond by a process of co-operation and form dense cushion-like masses. In the high Alps many examples of this are seen. The individual plants are closely huddled together in the form of a tuft, not only on account of warmth and natural protection and to prevent their being blown away by rough winds, but also because the cushion acts as a sort of reservoir or sponge and prevents the little plants being dried up by the fierce rays of the sun.

The Moss Campion is a typical "Cushion plant." It is found abundantly all over the Alps, especially in the limestone regions between 5000 and 10,000 feet or even higher. It grows in open rocky places, often on the bare rock itself, and in the neighbourhood of glaciers, and may be found close up to the snowline. The bright green moss-like cushions formed of the dense clusters of leaves become sprinkled over with pinkish-purple star-like flowers in June, July, and August. Occasionally the flowers are white. The long conical root penetrates far into the soil or into some fissure in the rocks, thus securely anchoring the plant, and divides 


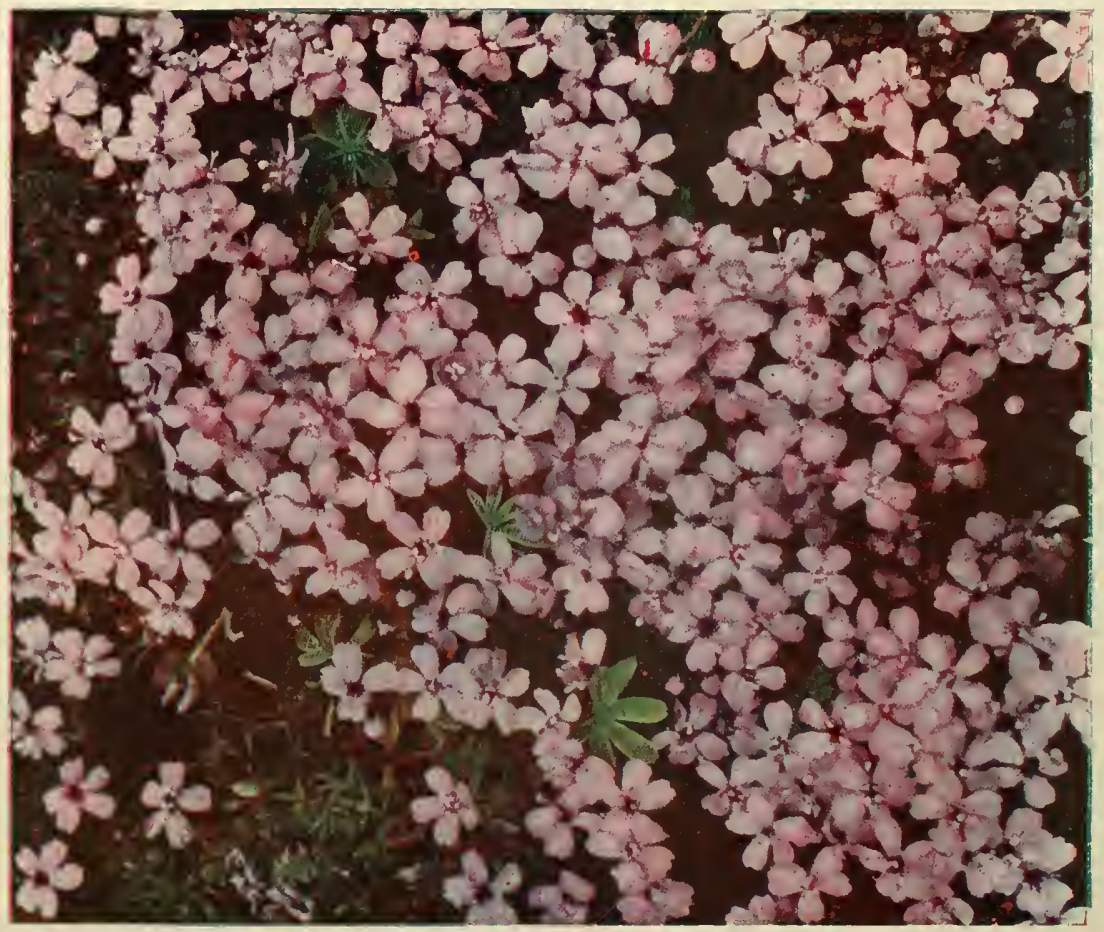

The Moss Campion or Cushion Pink. Siline a Courte tige. Stengelloses I.eimkraut oder Moos-Leimkraut. 
abore into numerous branches, which radiate in all directions and are thickly covered below with brown dead leaves and terminate abore in a rosette of bright green linear leaflets. The flowers, which are risited by many kinds of insects, are of three kinds. Rarely we find cushions of flowers containing both stamens and pistil in the same flower, but even here the pistil becomes ready to receive pollen before the stamens open so as to prevent self-fertilisation. Usually, however, the flowers are unisexual and contain stamens or pistil only, and staminate and pistillate flowers are borne on different cushions.

The Moss Campion is widely distributed in the mountain regions of Southern Europe, North America, and the Arctic regions. Silene exscapa closely resembles the abore, but is much less common. Its flowers are smaller and less brightly coloured, and the separation between calyx and flower stalk is more gradual and less abrupt than in the Moss Campion. Its seed-ressel or capsule is, moreorer, hardly longer than the remains of the caly $x$ which encloses it, whereas the capsule of the Moss Campion projects well beyond the enclosing calyx leares. 


\section{The Wood Geranium}

(GERANIUM SYLVATICUM)

Seventeen species of Geranium or Crane's-bill, so named from the shape of the seed, are met with in Switzerland, and several of them are rather difficult to distinguish from one another.

The Wood Geranium is found in England, but is not very common. In Switzerland it is exceedingly abundant on the borders of woods and in rich mountain meadows and pastures between 3000 and 7000 feet. Though a beautiful plant it is by no means welcome to the herdsman, for it is not good for fodder. The finely divided leaves are well seen in the photograph. The purple-blue flowers have more of a tinge of red in them when they first open. The Wood Geranium will be recognised by its erect stem, hairy above, leaves which are arranged opposite to one another, purpleviolet flowers with petals that are not notched in the middle, and sepals drawn out to a long point. The Brook Crane's-bill (Geranium rivulare) has white flowers varied with red, and the Meadow Crane's-bill (Geranium pratense) has larger flowers which tend to hang down, and the Blood Geranium (Geranium sanguinum) has unbranched flower stalks and notched petals. 
GERANIEM STLVATICLM. I.

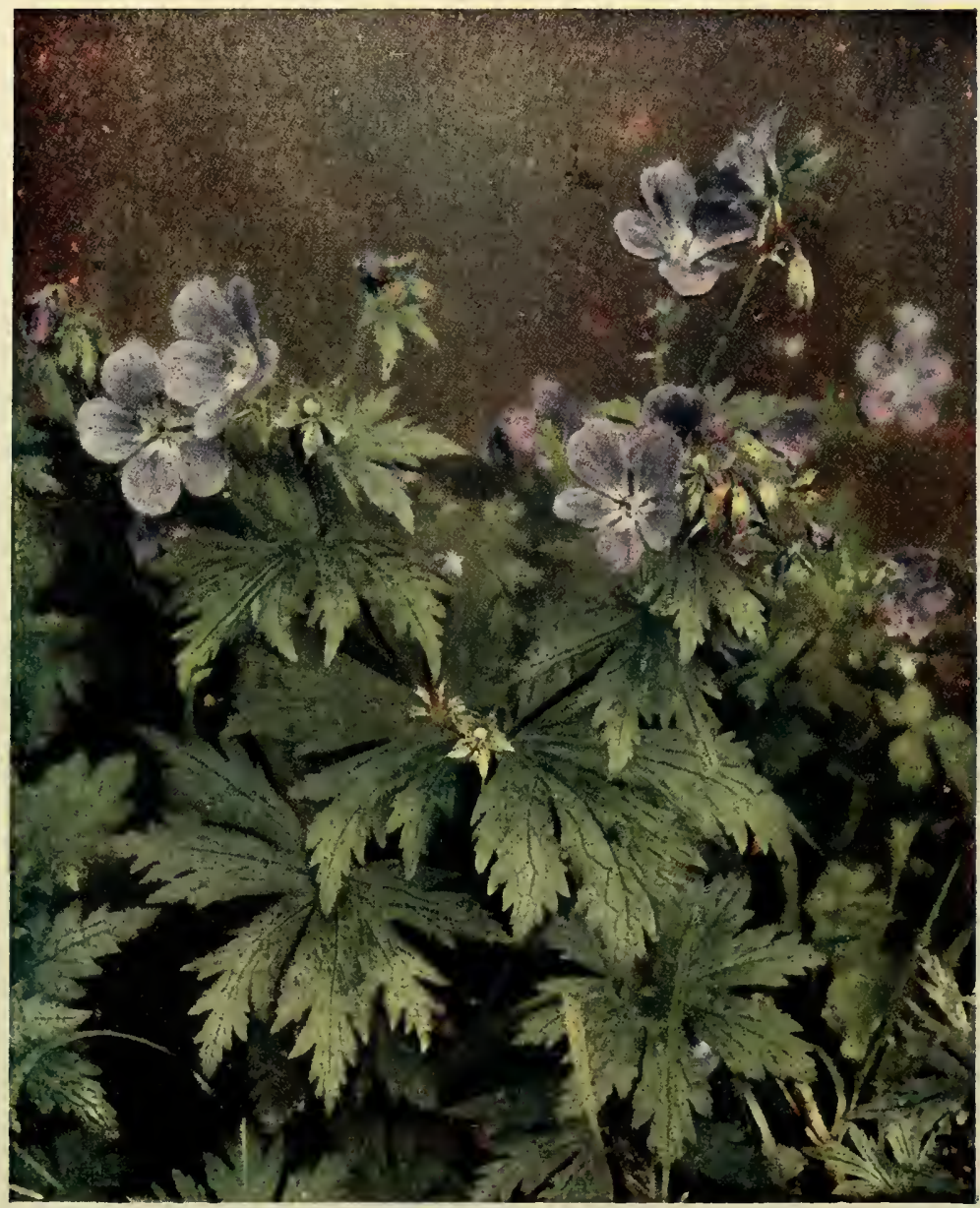

The Wood Geranium or Wood Crane's-bill. Giéranie des Forêts. Wald-Storchschnabel. 




\section{The Alpine Clover (TRIFOLIUM ALPINUM)}

THis plant is the most beautiful and most sweetly scented of all the clover tribe. The long conical root stock which penetrates far into the soil terminates above in many radiating branches. On these are borne the long stalked leaves, composed of three narrow leaflets with serrated margins. The flowers, which are larger than those of any other clover, are borne in a group of four to twelve on top of a long flower stalk. They begin to appear early in June and continue coming out till the end of August; they are usually of a delicate pinkish-purple colour, but occasionally a cream or white variety may be found. The Alpine breezes are often filled with their delicate fragrance. When the flower fades the petals are not shed, but remain attached to the seeds and act as wings which aid in their dispersal. Unlike most of our English clovers, which are annuals, the Alpine clover is a perennial and lives for many years, throwing up fresh leaves and branches every spring. The thick solid rootstock of some of these plants must be many years old. This species is very common in the meadows and pastures in the central Alps between 5000 and 8000 feet, where it grows in greatest abundance and especially luxuriantly on primary granitic rock. It is probably a true native of the Alps, but is also found in South Tyrol, the Pyrenees, and the Carpathians. 


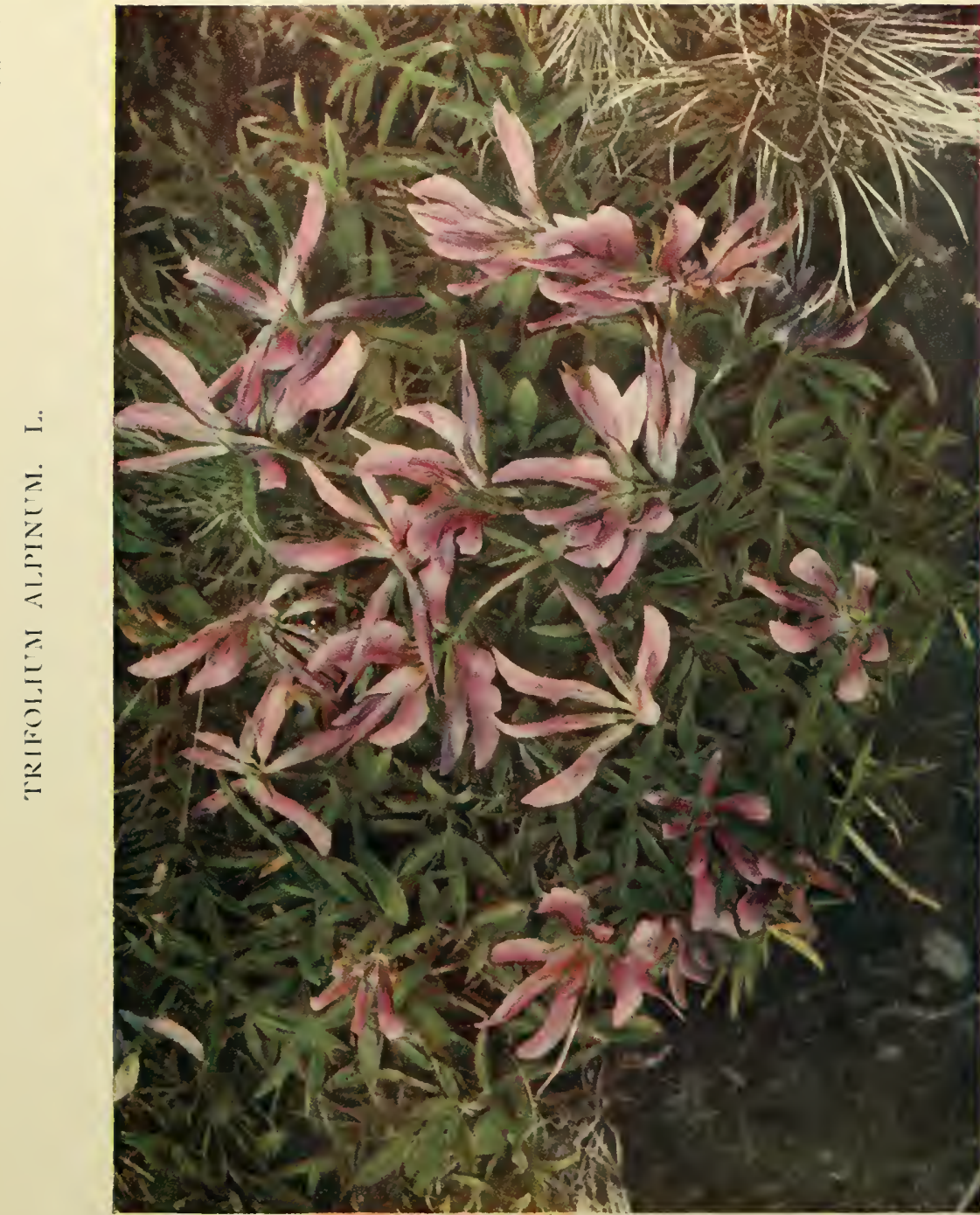


The Alpine clover will be readily recognised by its fewflowered flower-heads and narrow pointed leaflets arranged in groups of three. The much rarer Trifolium pallescens is perhaps a little like the pale flowered variety, but it has many flowered flower-heads and ovate leaflets. 


\section{The Brown Clover (TRIFOLIUM BADIUM)}

UNLIKE the greater number of Alpine plants which persist from year to year the Brown Clover is a biennial, that is to say, its life is limited to two years, and at the end of its second summer the plant dies off. It is found abundantly in the limestone districts of Switzerland between 4000 and 7000 feet, and flowers in July and August. It grows in meadows and pastures, and seems to prefer a moist, open spot, where the competition with other plants will be less severe. Thus it is met with on moraines, on the fresh soil brought down by avalanches and streams, and even on the dirt heaps around Alpine cow houses. The much-branched brownish stem bears the rather long-stalked leaves, composed of three leaflets with serrated margins and blunt points. The flowerheads, made up of numerous florets closely packed together, are at first of a golden yellow colour. As the individual flowers fade-and the lowest fade first - they become brown and scale-like and turn downwards, and the dry brown corolla remaining attached to the seed forms an important aid in its dispersal by the wind. The Brown Clover is widely distributed in the mountain regions of Central Europe. It will be readily recognised by its globular flower-heads of yellow flowers and bright green leaves made up of three leaflets, which are arranged opposite to one another on the upper part of the stem. 
TRIFOLILM B.IDILM. SCHRER.

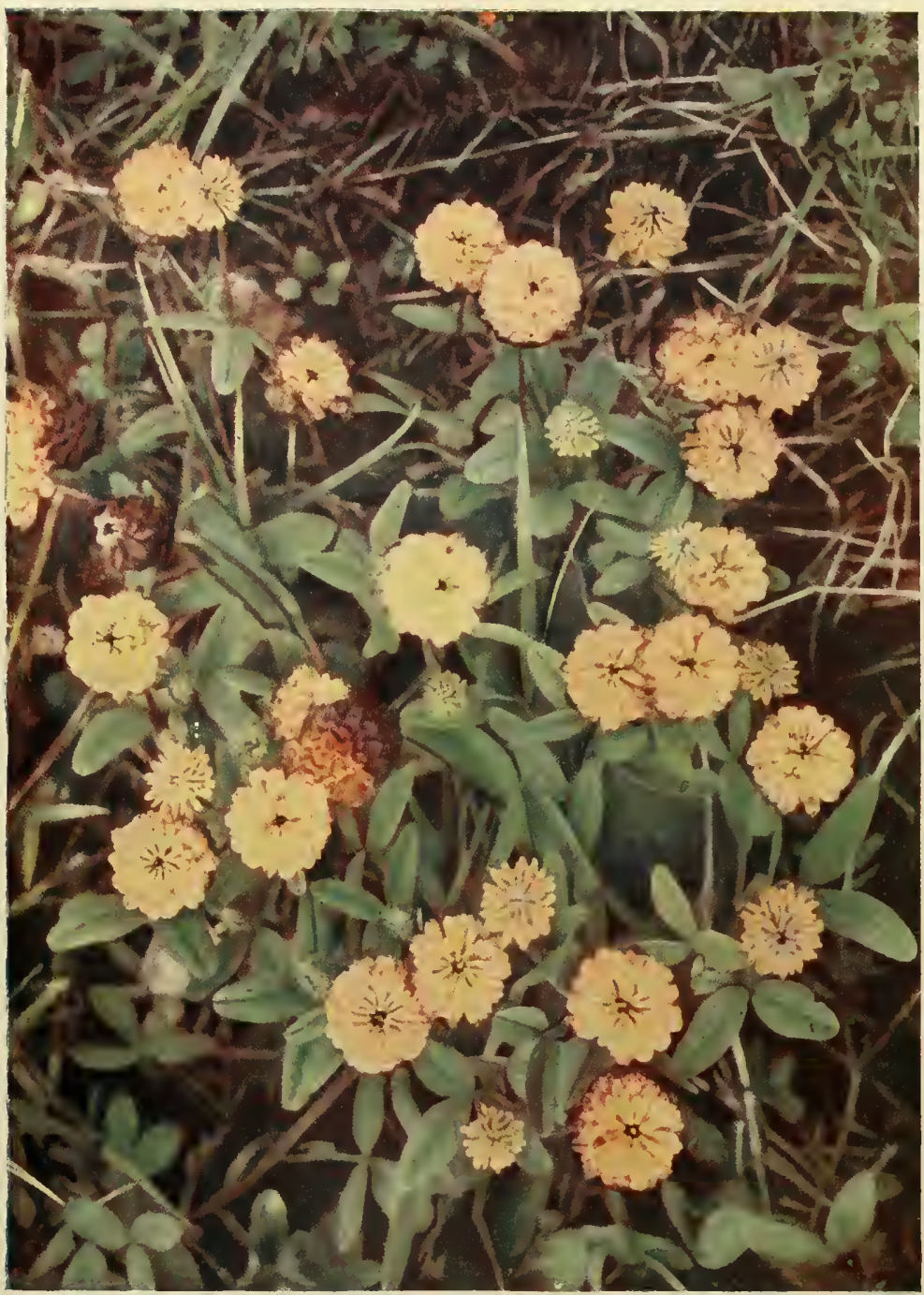

The Brown clover.

Trèlle brun.

Briunlilee. 

Trifolium spadiceum is very like the above, but is not so common. Its flower-heads become more elongated and change to a darker brown tint than those of the plant here photographed as the flowers fade. 


\section{The Cold Mountain-Lentil}

(PHACA FRIGIDA)

The Cold Milk-Vetch or Mountain-lentil-to give a literal translation to its popular Swiss name, for it has no Englishis a typical Alpine plant, found in fair abundance between 5000 and 8000 feet, perhaps most frequently in limestone districts. In rocky places or mountain meadows it often grows in profusion, but it seems to avoid the pastures. The stem is usually unbranched, about 6 or 8 inches high, and bears the pale yellow or cream-coloured flowers and the bright green leaves, made up of four or five pairs of leaflets with an odd one at the tip. The leaves are arranged in pairs opposite to one another, and where they join the stem a couple of pale broad wing-like stipules are attached. It is unfortunate that these are not well seen in the photograph, for they are the most characteristic thing about the plant. The Cold Mountain-lentil has an extensive range, being found in mountain districts all over Europe, Northern Asia, North America, and in the Arctic regions. It is thought to have originated in the Steppes of Northern Asia.

Phaca alpina differs from the above in being a somewhat taller plant with branched stem, deeper yellow flowers, leaves made up of nine to eleven pairs of leaflets, and smaller, narrower, stipules. 
$\underset{3}{3}$

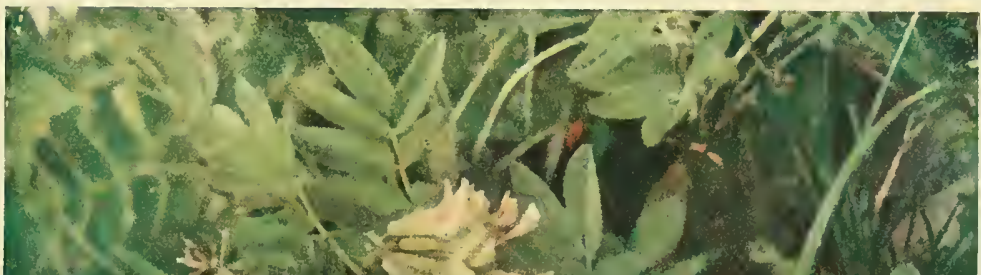

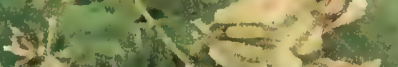

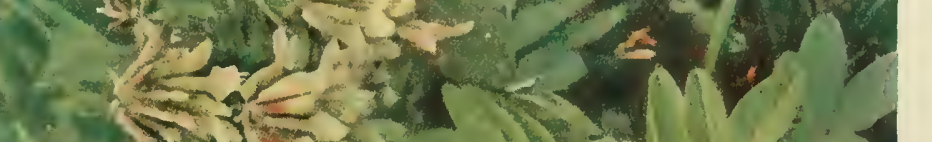

D. $2(x), 1), 1,0$

Coth and at
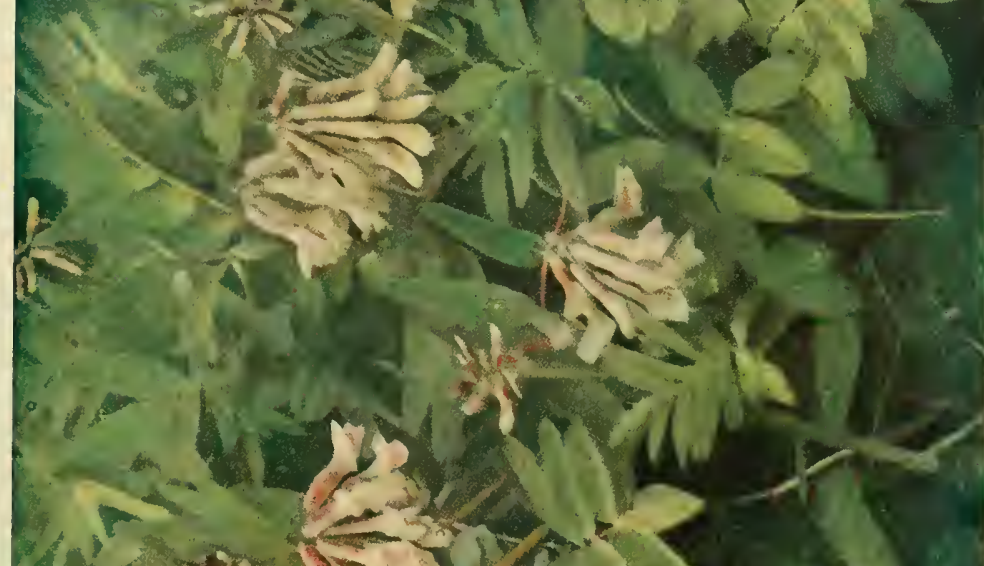

$\int_{4}$

$+x^{2}$

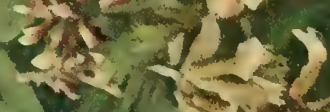

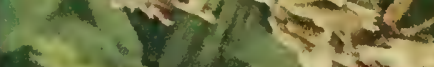

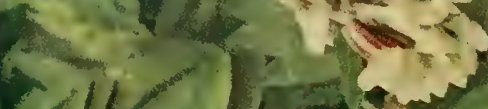

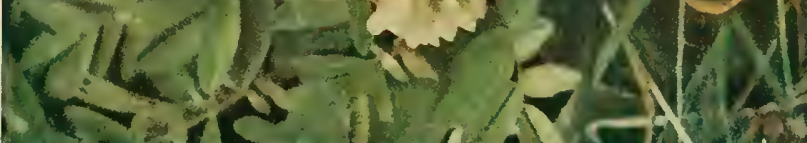

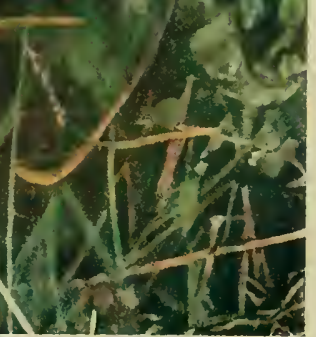

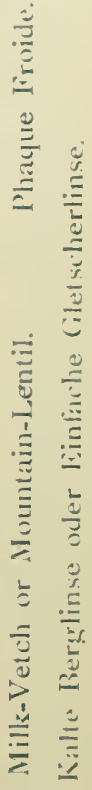

¿

$\stackrel{\ddot{E}}{E}$ 




\section{The Dull-Flowered Sweet Clover or Alpine Sainfoin (HEDYSARUM OBSCURUM)}

THE Alpine Sainfoin is the only member of the sixteen European species of Hedysarum (Sainfoin) that is found in Switzerland. The plant consists of a thick, dense underground stem which persists from year to year and serves as a storehouse for food. Underground branches extend outward from this in various directions and give rise to ascending shoots bearing leaves and flowers. The short stalked leaves bear eleven to nineteen leaflets which are arranged in pairs; the purple-red flowers occur in clusters. The flowers are visited by bees on account of the honey they contain. By means of a sort of catapult arrangement, which only goes off when the bee settles on the flower, the body of the insect becomes dusted with pollen and as the bee travels from flower to flower pollination is effected. In the Western Alps a variety of this plant with yellowish flowers is occasionally to be found. The seed ressel of the Alpine Sainfoin is very characteristic. It is not unlike an ordinary pea-pod, but is smaller, more flattened, and divided into two or three oval segments by constrictions. The plant is fairly abundant between 5000 and 8000 feet, and flowers in July and August. It is rare in meadows, but is found on the rocky borders of 
5
5
$=$

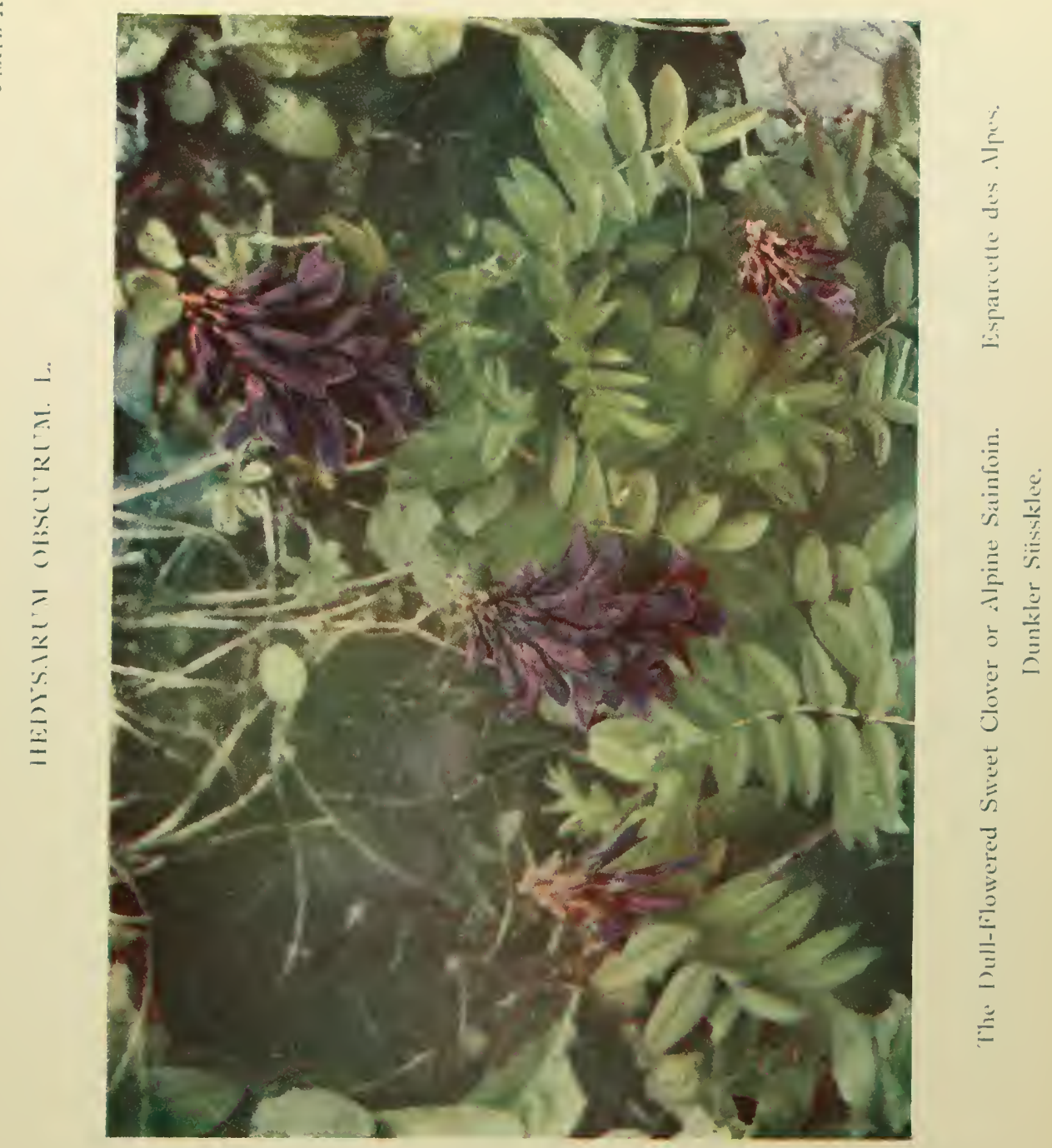



Alpine pastures and on the banks of streams. It is met with in all parts of the Alps, in the mountainous districts of Europe and Asia, and in the Arctic regions, and is thought to have taken origin in the Steppes of Northern Asia. It should be very easily recognised. The drooping habit of the flowers and the constricted seed-pods are most characteristic.

The flowers of this species have generally more red in them than those of the specimen photographed. 


\section{The White Dryas (DRYAS OCTOPETALA)}

THE White Dryas, or Silver-herb as the Swiss call it, is a characteristic Alpine plant which is found all over Switzerland between 3000 and 8000 feet, and even descends to the plains with some of the rivers. It is common in dry mountain pastures and rocky places, and seems to grow best on limestone soil. Often the bare surfaces of rocks and boulders are thickly covered with its matted growth, which persists from year to year as soil gradually accumulates around it.

The thick dense rootstock gives rise to long trailing branches, which extend in all directions and bear the leaves and flowers. Associated with the root tips is a curious fungus growth, which from its constant presence is thought to be of value to the plant. The tough leathery evergreen leaves have rolled back notched edges. Their upper surfaces are dark green, smooth, and polished, and devoid of the stomata or little pores by which air is absorbed by green plants generally; the lower surfaces are covered by thick white felt-like hairs. The flowers, which appear from May till July, resemble those of the Alpine Anemone, but are smaller. They have usually eight petals, hence the Latin name. Inside the petals are a large number of stamens arranged in the form of a ring, and inside these again a honey secreting gland which surrounds the mass of closely packed 
5
$\vdots$
$\vdots$

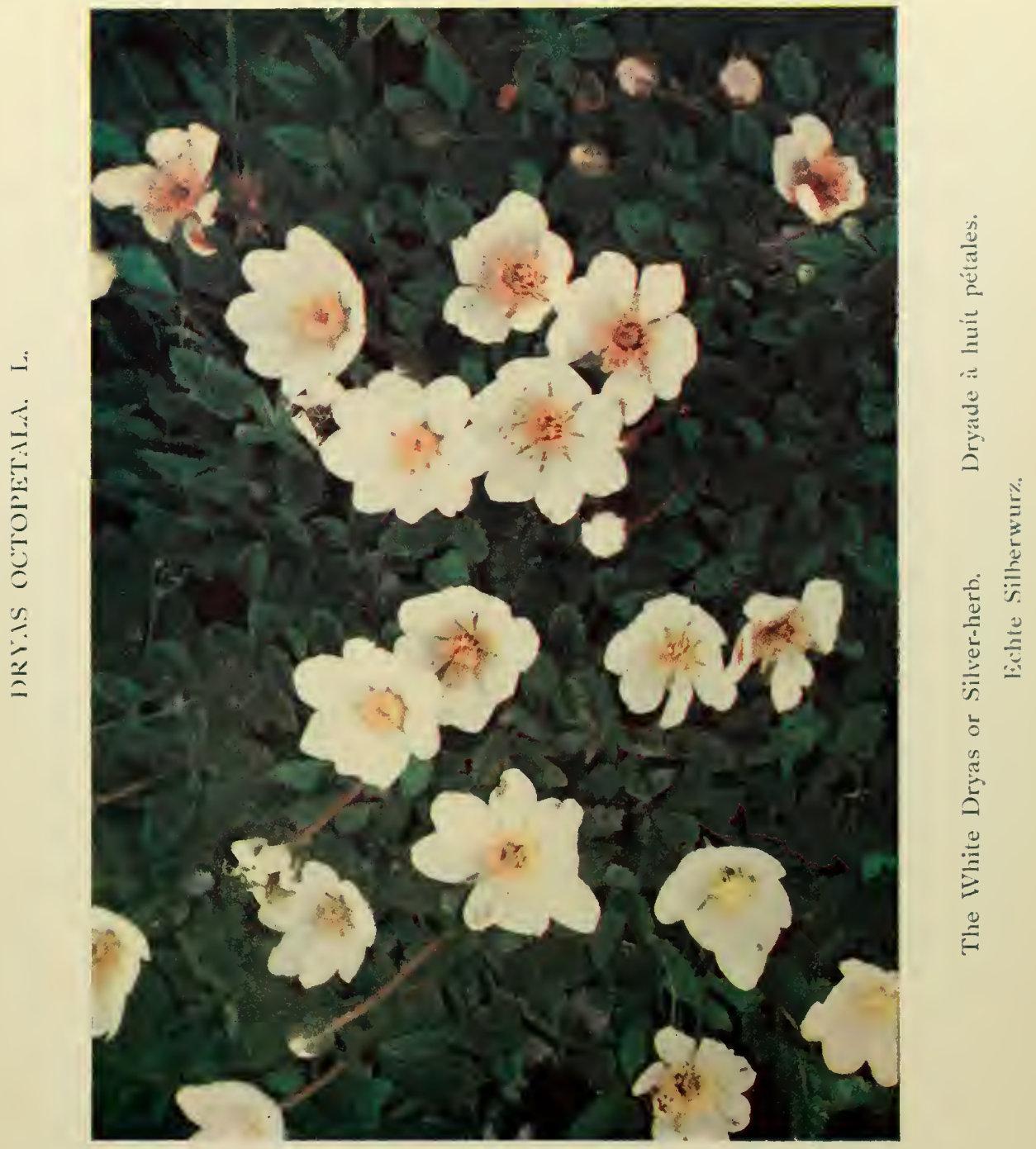


carpels in the centre of the flower. The carpels bear long silky styles, which grow out into beautiful feathery appendages as the seeds ripen-another point of resemblance to the Alpine Anemone. The carpels become ready for pollination before the stamens shed their pollen. Then the outermost stamens open, and only after several days have elapsed do the innermost stamens become mature. A little consideration will show how wonderfully this arrangement is adapted to favour the cross-fertilisation of the carpels by pollen brought from another flower by the agency of insect visitors. Should this, for any reason, fail, self-fertilisation will almost certainly be effected by means of the pollen from the innermost stamens. If a large number of plants of the White Dryas be carefully examined some will be found with flowers containing both stamens and carpels, as above described, while others, less numerous, have flowers with stamens only. These will of course produce no seeds. Some plants, again, will be seen to bear both kind of flowers. The White Dryas is found in the mountainous districts of Europe and in the Arctic regions of the new and old worlds. The plant will be readily recognised, for its leaves are quite different from those of an anemone. 


\section{The Alpine Rose (ROSA ALPINA)}

The Alpine Rose or Dog-Rose must not be confounded with the Alpenrose. The resemblance is only in the names, for the Alpenrose so much beloved by the Swiss is really a rhododendron and quite a different plant. The Alpine Rose is a shrub sometimes 8 or ro feet high, and only a single branch is shown in the photograph. It is found on the borders of mountain woods and in bushy places, from the lower slopes up to about 7000 feet, and flowers in May, June, and July. The leaves consist of seven to eleven leaflets, and there are broad stipules at the base of each leaf. The sweet-scented flowers are of a rich rose-red colour. The sepals are exceptionally long and project beyond the petals; this is especially noticeable in the bud. The fruit or hip is flaskshaped and rather narrowed at the base. Thorns are as a rule absent from the flowering branches, but are generally to be found on the lower and younger shoots, which point downwards. Sometimes they are absent altogether. The Alpine Rose is found pretty abundantly in the mountain woods of Southern and Central Europe, but does not extend to the North. Thus it grows in the Pyrenees, Auvergne, the Balkans, and in one part of the Black Forest.

The Dog-Roses are phenomenally difficult to distinguish from one another, and as many as fifty Swiss species are 
$\vdots$
$\Xi$
$\Xi$
$\vdots$ 

described. The characteristics above mentioned, and especially the high elevation at which it is found, will assist in the recognition of the present species. By the arrangement and character of the leaves and spines and the shape of the fruit, the Alpine Rose itself has been sub-divided into some thirty sub-species. 


\section{Fleischer's Willow-Herb}

(EPILOBIUM FLEISCHERI)

This plant is fairly common in the Alps and grows in dry stony places, especially amongst the boulders of dried-up torrent beds and beside some of the streams; with some of these it descends towards the plains. Like not a few of the ess common Alpine plants, where it is found at all, it is usually met with in great abundance. The flowers which open out in July are of great beauty, and their arrangements to prevent self-pollination are of considerable interest. The stamens first ripen, and while these are held erect the stigma is bent downward and the four segments into which it is divided above are closely pressed together. (Most of the flowers are in this stage in the photograph.) When the pollen is shed the stamens bend downward, and not till then does the stigma rise in the centre of the flower and its four lips become separated from one another.

The flowers of Fleischer's Willow-herb closely resemble those of the Rose-bay (Epilobium angustifolium), common in bushy places all over England, Switzerland, and Central Europe. But the Rose-bay is a bigger plant with tall, usually unbranched stem and much larger leaves, which are veined underneath. As will be seen by the photograph, the leaves of Fleischer's Willow-herb are narrow and lance-shaped, and the few veins that can be made out 
$\vdots$
$\overline{1}$
$\vdots$
$\vdots$
$\vdots$

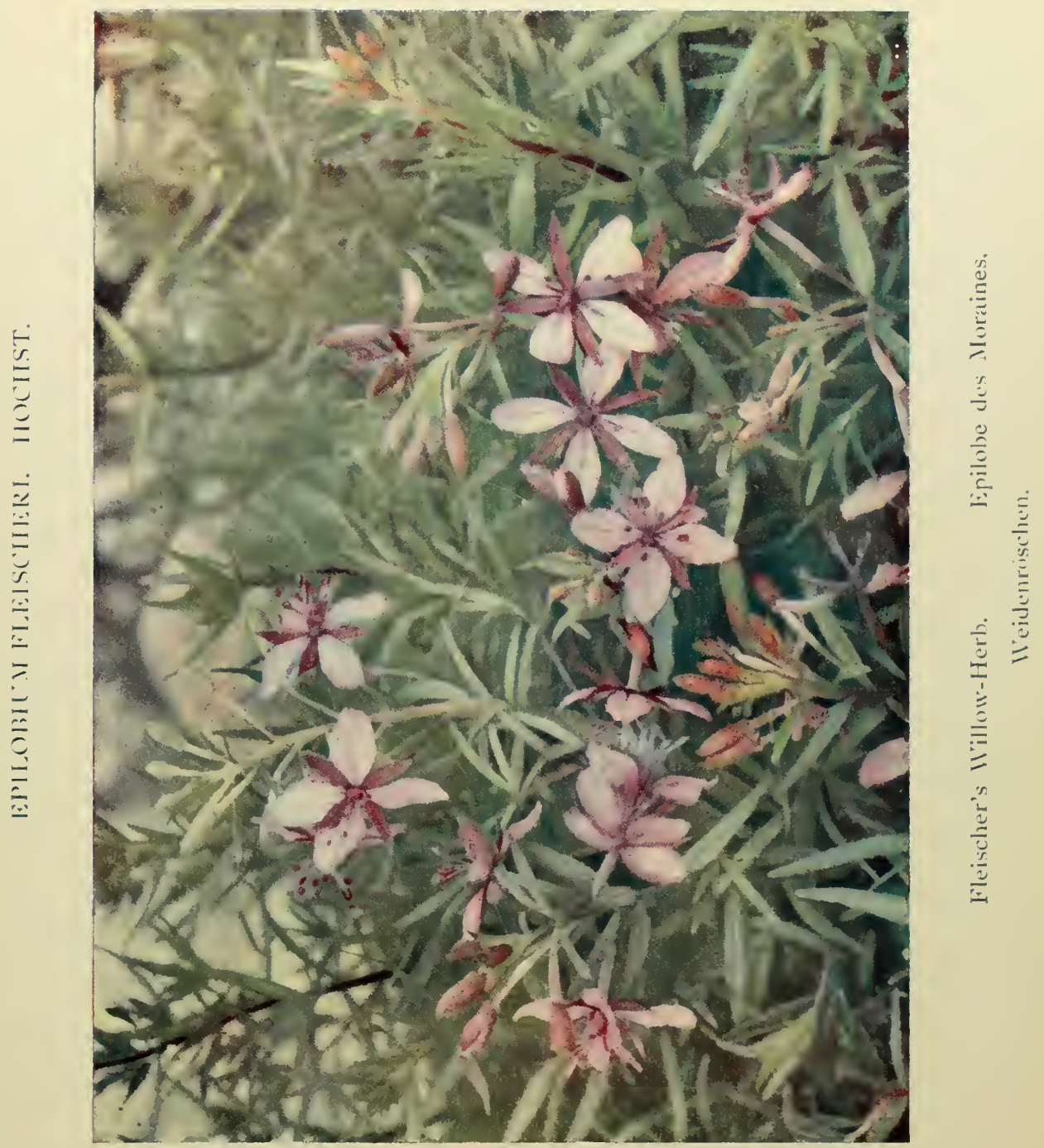



are all parallel to one another. Closely resembling the plant here photographed is the Rosemary-leaved Willow-herb (Epilobium rosmarinifolium). Its leaves are usually more numerous, narrower, and more strap-shaped, and its stem is taller and, as a rule, more branched. But the most constant difference between the two plants is to be found in the length of the stalk which bears the stigma (style). This is as long as the stamens in Epilobium rosmarinifolium, but only half this length in Epilobium Fleischeri. 


\section{The Mountain House-Leek (SEMPERVIVUM MONTANUM)}

Several varieties of House-leek are found in Switzerland. They grow in dry, rocky places, where moisture is scarce and where they are exposed to the fierce heat of the sun. Their succulent leaves, covered by a thick, almost leathery, cuticle, are arranged in rosettes, and serve as storehouses for water. The plants grow slowly and in clusters, and when each one has accumulated sufficient strength it throws up a long central stalk bearing star-like flowers, and dies as the seeds mature. The house-leeks are reproduced not only by means of seeds, but also by runners, which extend outward and bear a small rosette of leaves at their extremities. Some of these can be made out in the photograph. Some of the Saxifrages closely resemble the house-leeks in habit of growth, but are less succulent.

The Mountain House-leek is common all over the Alps between 4000 and 8000 feet, or even higher in certain parts. It seems to grow best on primary granitic rock. The wedge-shaped rosette leaves are covered with short glandular hairs. The rosettes are unfortunately not well seen in the photograph, the leaves that can be made out being mainly those of a species of Primula. From the centre of the rosette the flower stalk arises. It is some 3 to 6 inches long and is covered with succulent leaves with 


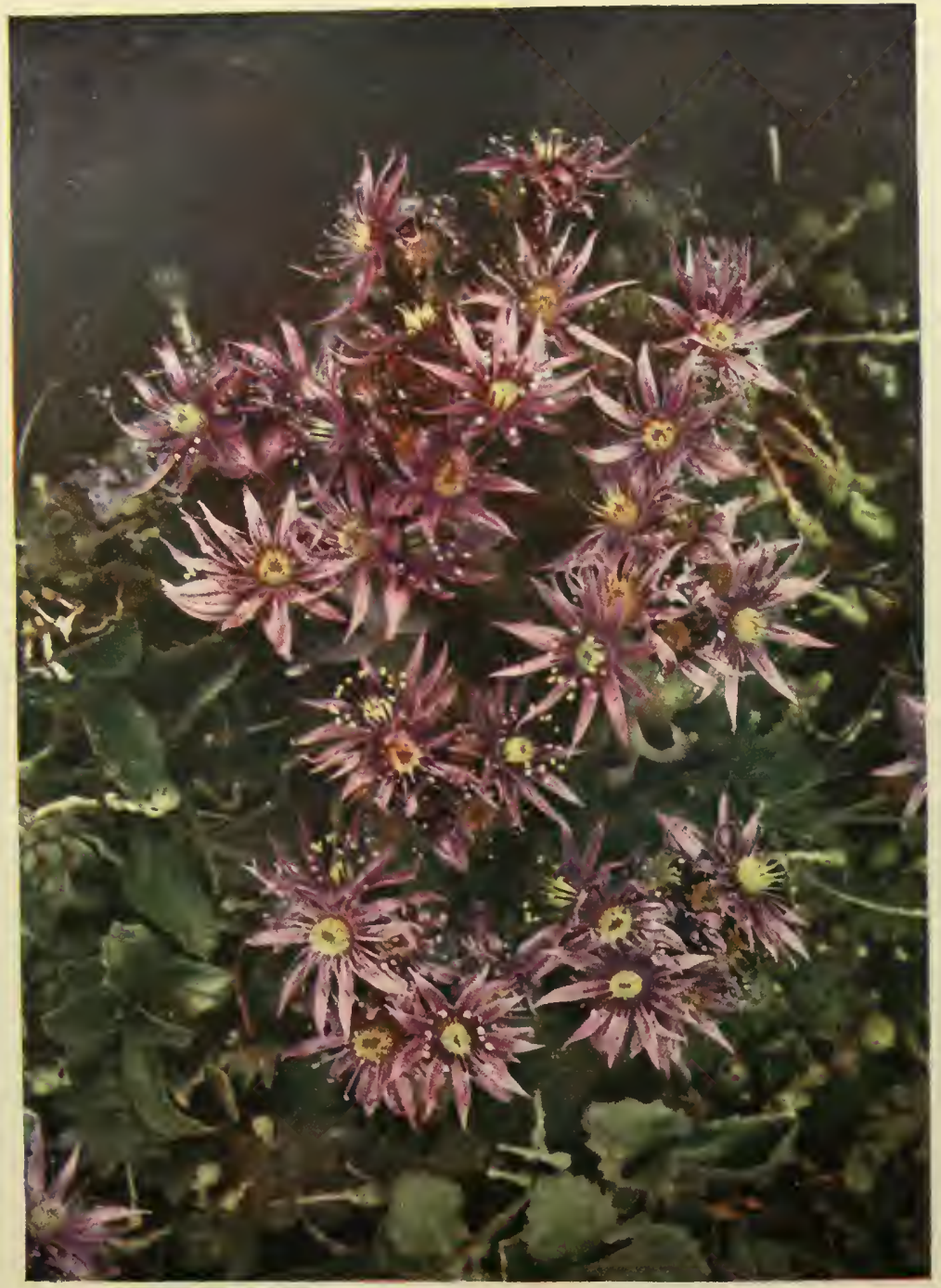

The Mountain Houre-leek. Juubarbe des Montagnes.

Berg-Hauswurz. 

reddish tips. Above it divides into branches which bear the beautiful star-like flowers. The flowers, which appear in July and August, are usually of a pale red colour with a darker central stripe to each petal. A variety with creamcoloured petals is very occasionally found.

The Cobweb House-leek (Sempervivum arachnoideum) is not unlike the plant here photographed, but will be readily distinguished from it by the long white hairs borne at the tips of the rosette leaves, which become interwoven with those of adjoining leaves to form a spider's-web-like structure. Its flowers are a brighter crimson than those of the Mountain House-leek. 


\section{Sempervivum Funckii}

Not unlike the Mountain House-leek photographed on the previous page is Sempervivum Funckii. It is not a common plant, being only found in Eastern Switzerland, the Tyrol, the Carpathians, and a few other mountainous districts, and does not seem to have acquired any local name. Compared with the Mountain House-leek the rosettes of leaves are a little smaller. They are covered with much longer hairs, which are not, however, twisted together into a spider's web like those of the Cobweb House-leek. As will be seen the flowers are of a beautiful pale pink colour, and each petal has a stripe of a darker tint running down its centre. The plant grows in rocky places.

The Common House-leek (Sempervivum tectorum), which is often seen in England growing on old walls and on cottage roofs, where it is supposed to protect from lightning, is also found in Switzerland. It is fairly common in dry, rocky places, and ascends from the plains to 7000 feet. Its purple flowers are not unlike those of Sempervivum Funckii, but its wedge-shaped rosette leaves are only provided with hairs along their margins, and are armed with sharp spines at their extremities. It is, moreover, a much larger plant. The rosette leaves of Sempervivum Wulfeni, another Alpine species, are very like those of the Common House-leek, but the plant is readily distinguished by its yellow or greenishyellow flowers. It grows on primary rock between 6000 and 8000 feet, and is rather uncommon. 


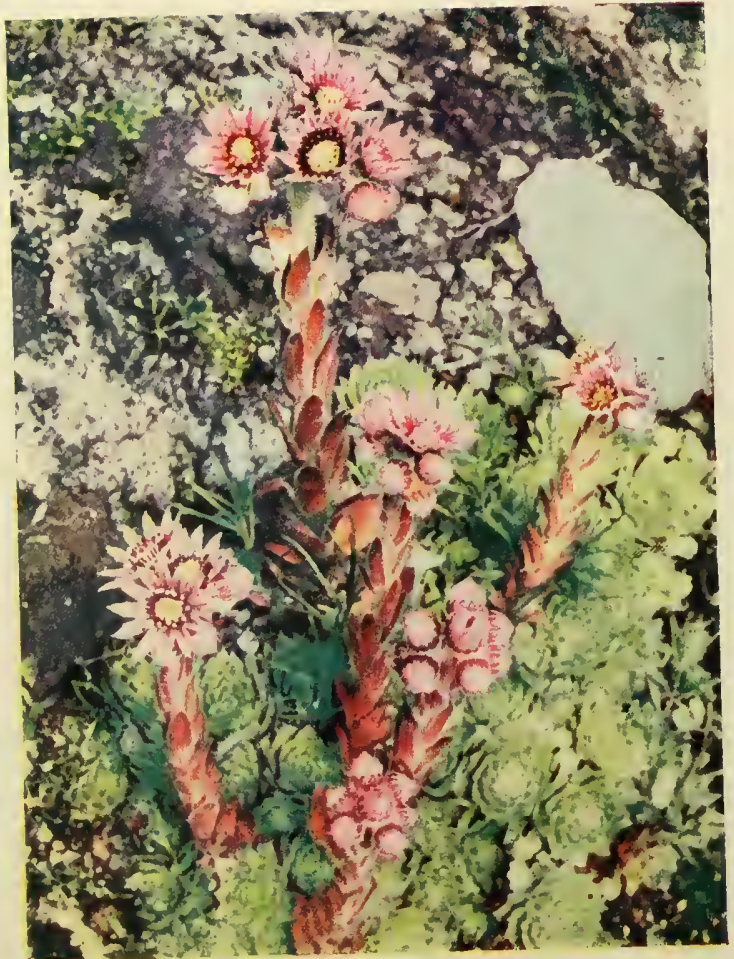

Funcke's House-leek. Joubarbe de Funcke.

Funcke's Hauswurz. 




\section{The Evergreen Saxifrage (SAXIFRAGA AIZOIDES)}

The Saxifrages have been extraordinarily successful in the Alps. Some thirty different species, some of them exceedingly common, are met with in Switzerland.

The Evergeen Saxifrage is one of the most abundant. It grows in moist rocky places, at the foot of glaciers, and on the banks of mountain streams and waterfalls. It ascends to 9000 feet in places and descends almost to the plains with some of the rivers. The plant grows in tufts. The erect flower stems are covered by the narrow, succulent leaves, which have hairs along each margin; they terminate in branches bearing four to eight flowers. The star-like flowers, which appear in July and August, are made up of five brightly coloured petals alternating with five green sepals. The petals may be lemon yellow with orange red spots, or, as in the specimen here photographed (var. atrorubens), pure orange red. Next comes a ring of ten stamens with dark red pollen, and then the showy ring-like nectary and the two styles in the centre of the flower. The honey is so obvious and abundant that insects of all kinds-flies, bees, butterflies, and beetles-visit the flowers; but self-fertilisation is, in the main, prevented by the pollen being shed before the ovaries with their stigmata are ready for fertilisation. The Evergreen Saxifrage is to be found in 
SAXIFR.MGI MUOIDES. I..

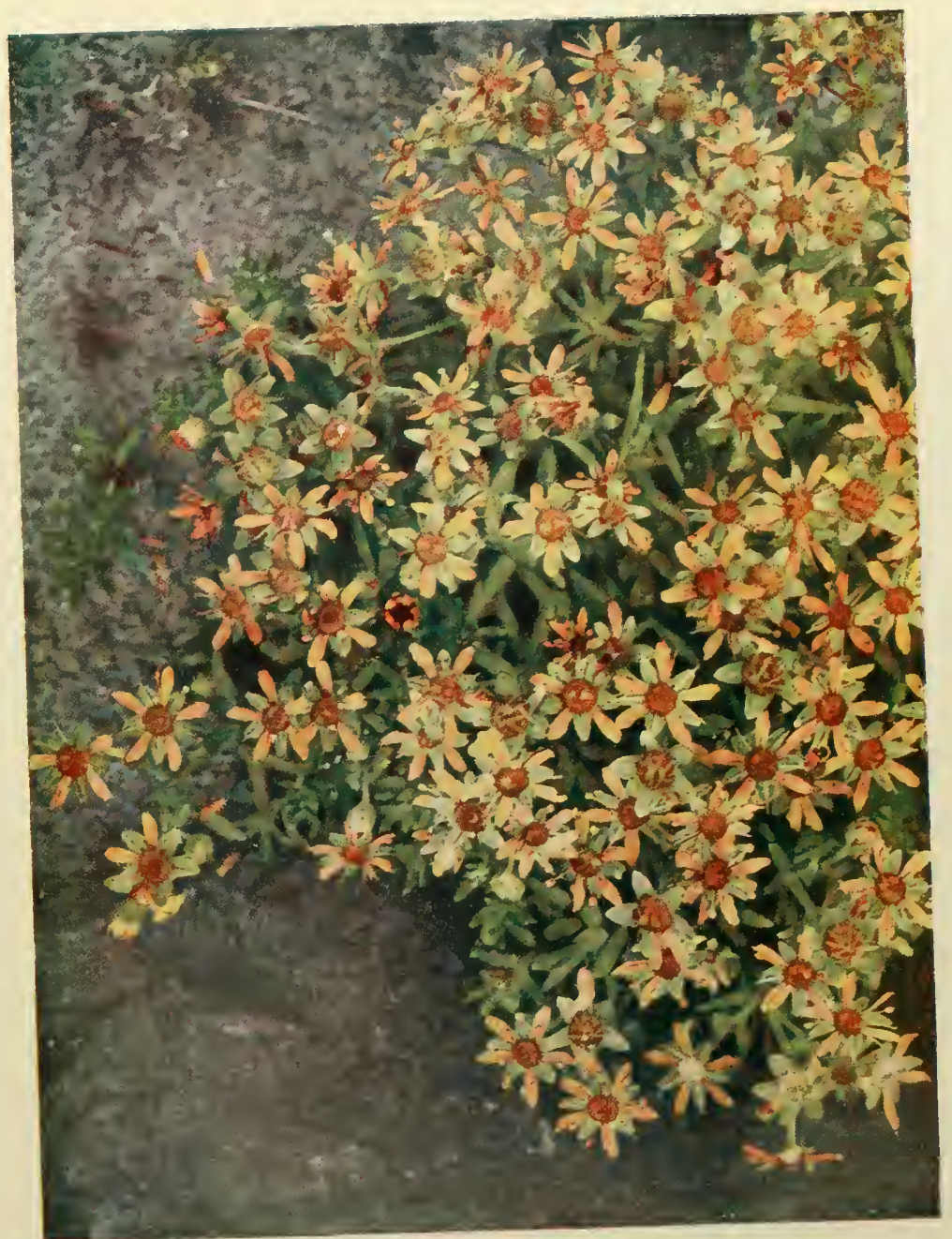

The Evergreen Saxifrage.

Saxifrage toujours verte ou Saxifrage pain d'Oiseau.

Immergrüner Steinbrch oder Borsten-Stcinbrech. 

all parts of the Alps, and is also met with in the Arctic regions.

With the help of the photograph no difficulty should be experienced in recognising the plant. From the Stonecrops, notably the Biting Stonecrop (Sedum acre), it is recognised by its possession of two styles. But several of the other Saxifrages resemble it much more closely. The Rough Saxifrage (S. aspera) has paler flowers and more hairy leaves. The Moss-like Saxifrage (S. bryoides) has a moss-like growth and the flowers are borne on long, usually unbranched, flower stalks. Saxifraga Sequieri has more flattened leaves, and Saxifraga Hirculus, which is rare, has two raised spots at the base of each yellow petal. 


\section{The Large Astrantia (ASTRANTIA MAJOR)}

This tall and handsome plant is common from the lower mountain region up to 6000 feet all over Switzerland. It grows in meadows, bushy places, and mountain woods. Several long-stalked leaves rise directly from the root stock. They are of a large size, circular in general outline, and consist of five or six radiating lobes with deep depressions between them. The branched flower-stem, perhaps some 2 or 3 feet in height, bears relatively few leaves. Its various branches terminate in what appear to be single flowers, but what are really masses of tiny flowerets with short stalks all of the same length, surrounded by a sort of cup made up of radiating leaves. The individual flowers are greenish-white, often with a pinkish tinge, and the radiating leaves are pale pink, with a central green stripe and greenish tip. The flower-masses of the Astrantia are an excellent example of the way in which small and unattractive flowers combine together and form a structure, both large and conspicuous, to attract insect visitors. These floral societies are even better seen in the large natural order the Compositæ, of which our next four photographs are examples. The Large Astrantia flowers in July and August, and is met with in many of the mountain woods of Central Europe as well as in the Alps. It is occasionally found in England. 
ISTRANTIA VIAUR. I.

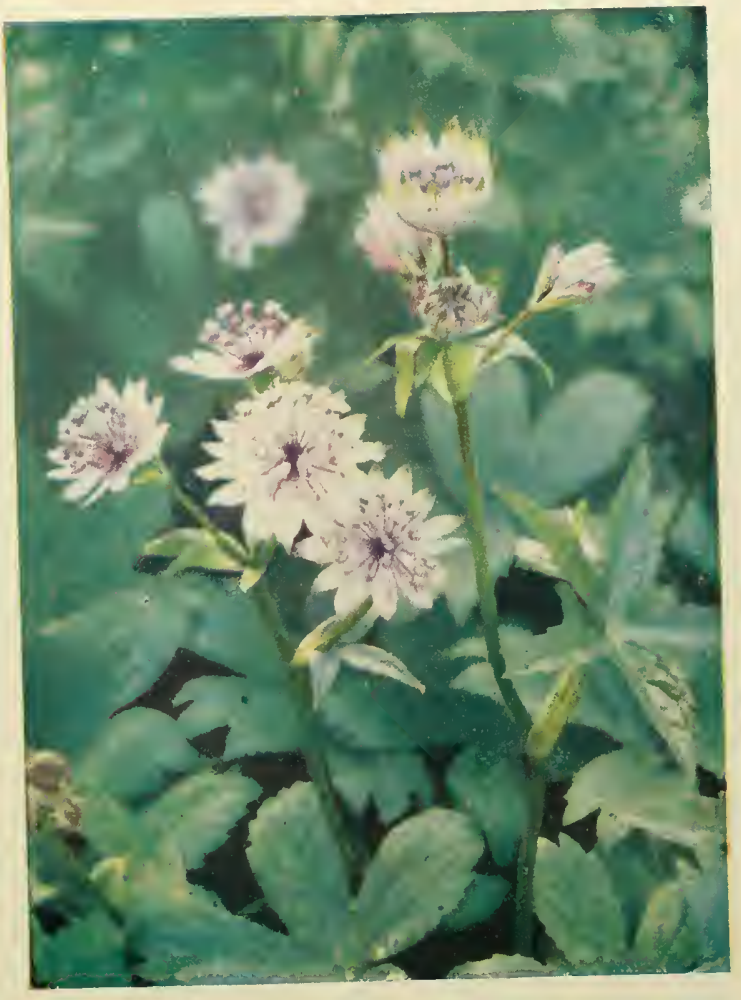

The Lirge Astrantia or Minter-liort.

Astrance Majeure ou Radiaire. Grosse Sterndolde. 

The Small Astrantia (Astrantia minor) is a much smaller and more slender plant. The notches in its leaves extend right up to the stem, thus completely separating the eight or nine leaflets from one another. The Hare's-ear (Bupleurum ranunculoides) somewhat resembles the Large Astrantia, but its flower-masses are entirely devoid of any tinge of pink and its leaves are strap-shaped. 


\section{The Alpine Starwort or Alpine Aster}

(ASTER ALPINUS)

The beautiful little Alpine Aster is found all over the Alps. It flowers in July, August, and September, but occasionally it may be found in bloom even as early as May. It grows in dry Alpine pastures, sunny meadows, and rocky places, not infrequently in company with the Edelweiss, between 4000 and 9000 feet; in a few places it extends much lower. The plant consists of a rosette of woolly tufted leaves, with a central stem bearing the solitary flower-head. In the higher regions the flower-stem is short, perhaps only 4 inches in length, but nearer the plains it may be 8 or 9 inches. In any case, however, the flower-head is large, an inch or two in diameter, and conspicuous on account of the broad purple ray florets, which contrast strongly with the golden yellow centre. The Alpine Aster is very widely distributed, being found in Northern Asia, Arctic America, and in most of the mountain ranges of Central and Southern Europe, but not in the far North.

Closely resembling this plant is the Alpine Fleabane (Erigeron alpina). It has narrower ray-florets, which are arranged in several rows and not in a single row like those of the Alpine Aster, and a branched flower-stem bearing 


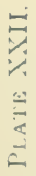

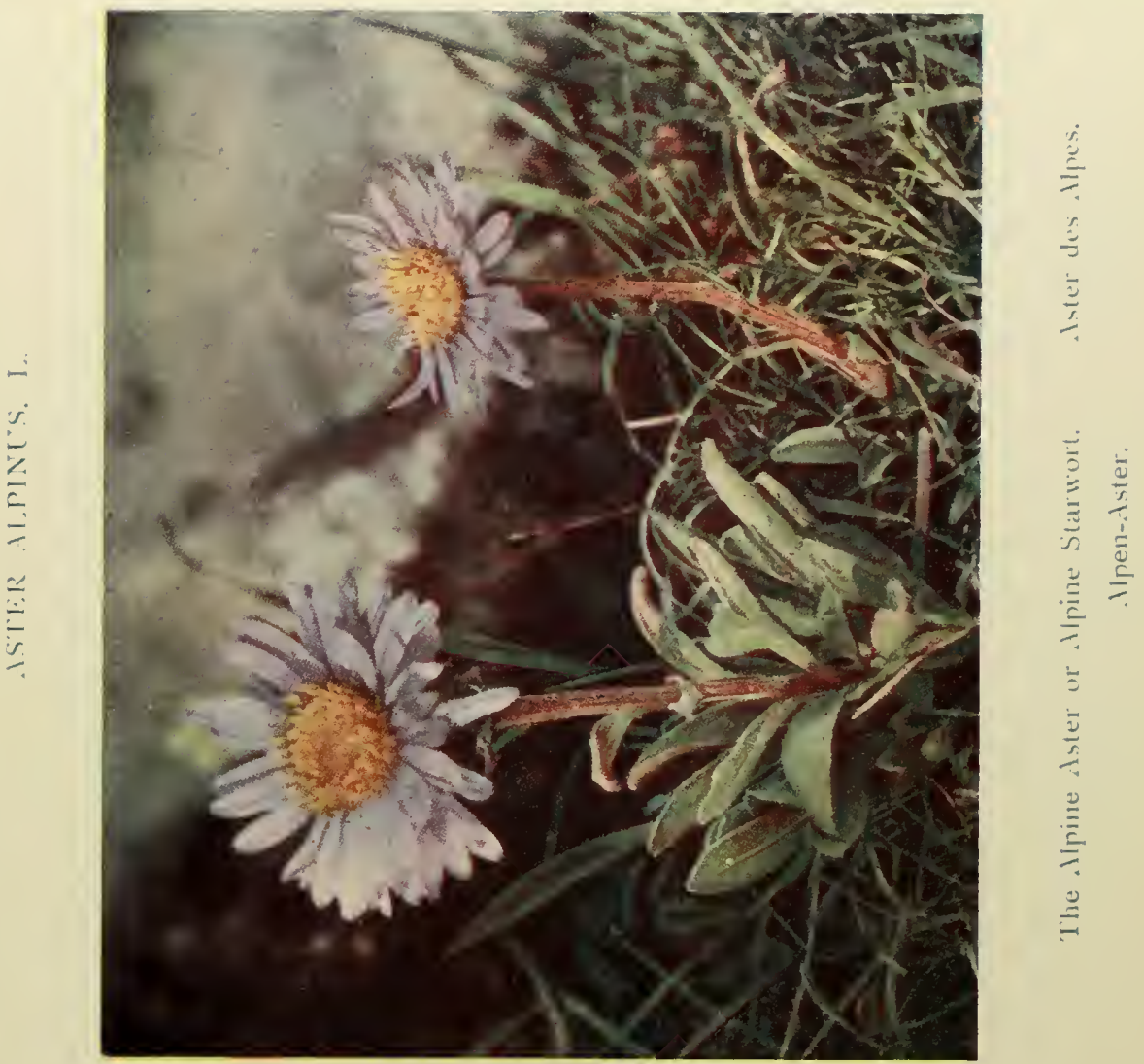



several separate flower-heads. The much rarer Aster Amellus differs from the Alpine Aster in the possession of a branched flower-stem and blue, not purple, ray florets. 


\section{The Cat's-Foot, Mountain Ever- lasting or Mountain Cudweed ( $A N T E N N A R I A$ DIOICA)}

THE Cat's-foot, which is, after all, perhaps the most suitable name for this curious plant, is abundant in the Alps from the lowest levels right up to 7000 or 8000 feet. It is found in dry places, on moors and heaths, and in dry open woods. It sometimes forms an unwished-for inhabitant of the mountain pastures where it is disliked by the herdsmen, for it is an undesirable plant for fodder. The leaves, like those of the Edelweiss, are covered with white woolly hairs, and the flower stems are also hairy. The flowers, which are pink or white, are dioicious, that is to say, the same flower does not produce both pollen and seed, and seed-forming and pollenproducing flowers do not occur on the same plant. As the pollen is not carried by the wind from flower to flower, the plant is entirely dependent upon its insect visitors for the fertilisation of its seeds, and without them no seeds will be formed. The plant is also spread by means of runners, which extend over the soil and take root at intervals. The Swiss peasants make wreaths of the Mountain Everlasting, which they wear as a charm, especially on Ascension Day. The plant is widely distributed, and is found in the North of England and Scotland, as well as most parts of Europe and the Polar regions. 
ANTENNARLA IOIOA. GÖRTNER.

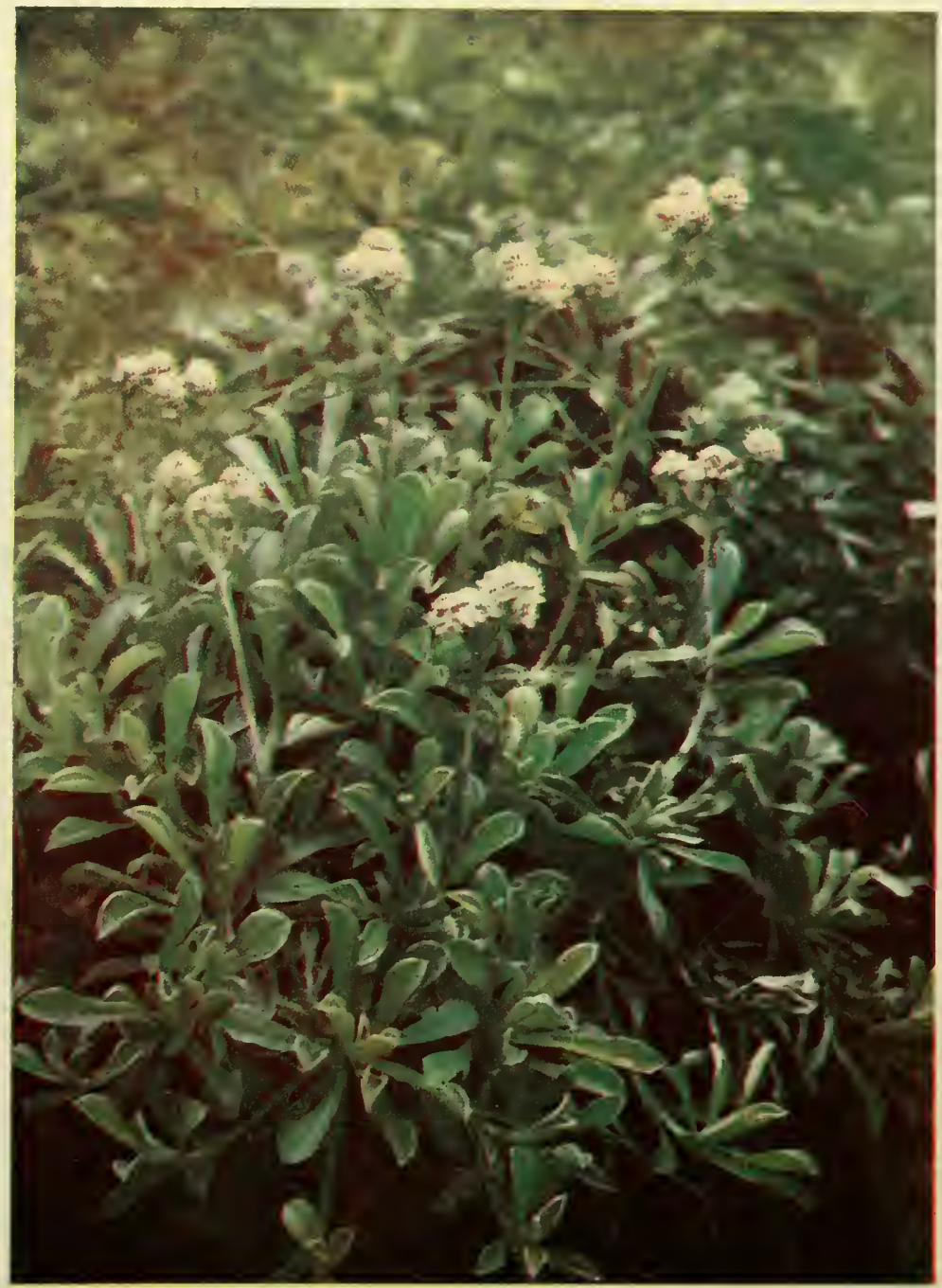

The Cat's-Foot, Mountain Everlasting, or Mountain ('udweed.

Gnaphale dioique ou l'ied de Chat.

Echtes Katzenpfitchen oder Mayensïssblumet. 

The Carpathians Cudweed (Antennaria carpatbica), which is also common in Switzerland, differs from the Cat'sfoot in that its flowers are brown rather than white or pink, and that it does not send out runners. 


\section{The Arnica (ARNICA MONTANA)}

A BRIGHT conspicuous plant is the Arnica, with its yellow star-like flower-heads. It grows in meadows, pastures, and on sunny moors, and is widely distributed in the Alps, from the lower mountain regions up to $8000^{\circ}$ feet. It is much less common in limestone than in other districts. Four broad green leaves grow from the root in the form of a cross. In the centre of these rises the erect flower-stalk some 8 or 9 inches long, and covered with glandular hairs. On the flower-stalk are borne the one or two pairs of leaves, without stalks, and arranged opposite to one another. The flower-heads are drooping in the bud, but when they open they are large and conspicuous and of a deep yellow colour. They give forth a faint, resinous, not very pleasing, odour. The outer or ray florets of the flower-head have long projecting strap-shaped petals. Their purpose is to attract insects to the floral society, and the less conspicuous florets in the centre of the flower-head produce just as good seeds. At first but a single flower-head is formed, but later on, if the plant is vigorous, buds appear in the axils of the opposite stem-leaves, and two more flower-heads appear. This is what has happened in the two specimens here photographed, and a second pair of buds is seen in one of them. It is interesting to note that a mould-like fungus is found con48 
KRNICI MONHAN.I. I.

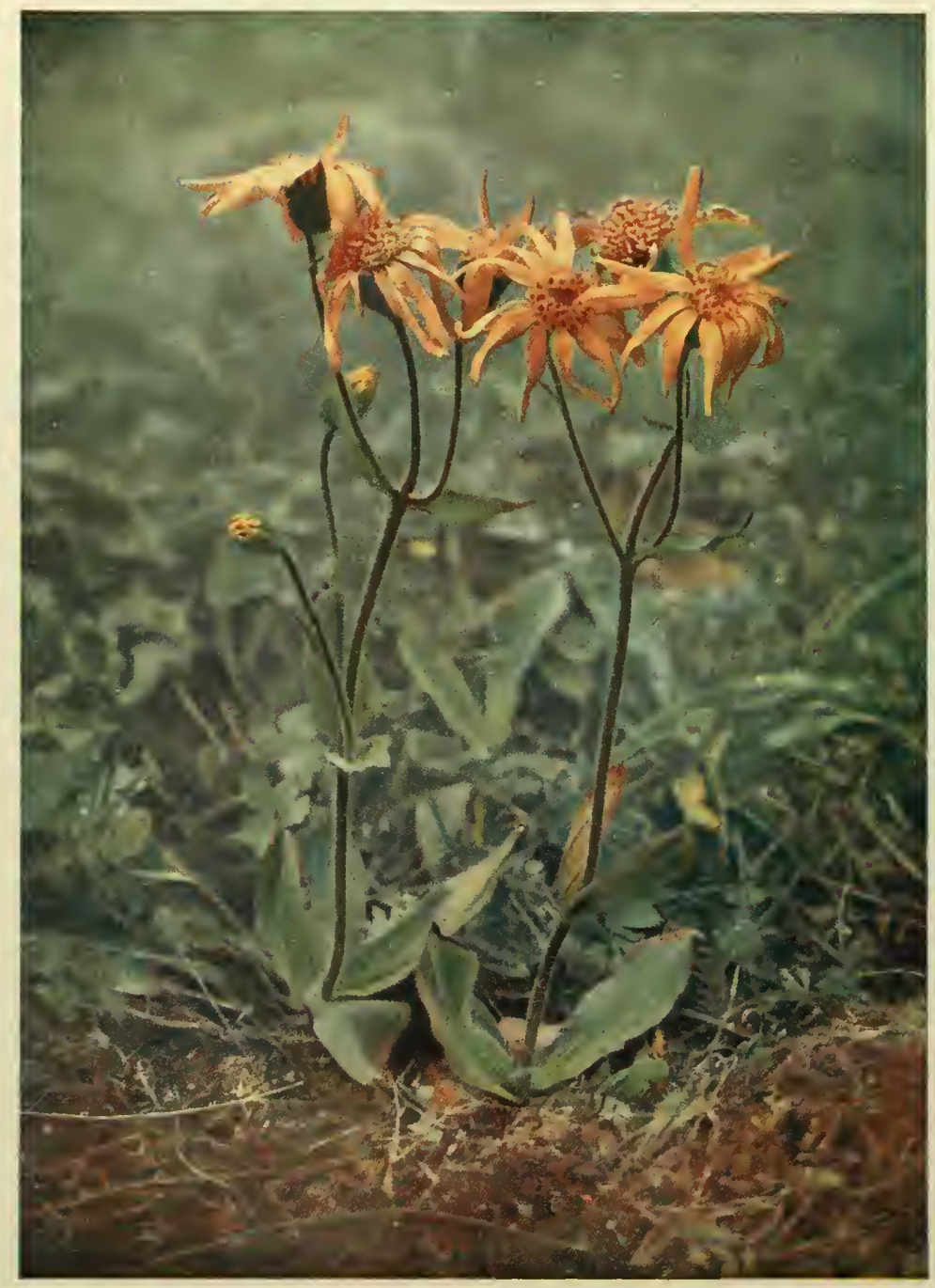

The Arnica.

Arnica.

Echtes Woblverlei. 
stantly associated with the roots of the plant. It is believed that the two plauts grow together to the mutual advantage of each, the fungus assisting the Arnica to obtain nourishment from the soil, and in return receiving from it some of the organic matter manufactured from the air with the help of light. The root has a bitter aromatic taste. From it is made the tincture of Arnica, which is often applied to bruises, apparently, however, without any very considerable influence upon them.

Several other Alpine plants, the Doronicum and Aronics, for example, have bright yellow flower-heads like the Arnica, but as no similar Alpine plant has pairs of opposite leaves on the flower-stem, the recognition of the Arnica becomes a very simple matter. 


\section{The Spiny Fuller's Thistle (CIRCIUM SPINOSISSIMUM)}

(See Frontispiece)

THIs stately and beautiful plant is common in all parts of the Alps, but is found nowhere else. It grows in moist places in the meadows and pastures, and beside the streams, between 4000 and 7000 feet. It is generally looked upon as a noxious weed by the herdsmen, but in one or two places the upper and more succulent parts are gathered and preserved as pigs' food for the winter.

The thick evergreen leaves, armed with formidable spines, are paler at the upper part of the stem where they surround the large brown flower-head. Usually but a single flower-head is borne by each plant, but each one produces some hundreds of seeds. Each seed has a feathery wing-like appendage, so that it may be more easily distributed by the wind. The Spiny Fuller's Thistle is usually some $3 \frac{1}{2}$ or 4 feet high, as was the specimen photographed, but in high altitudes the plant is more bushy and stunted. Under these conditions it is not unlike the Stemless or Alpine Carline Thistle (Carlina acaulis), which, in spite of its name, has sometimes a stem some 8 or 10 inches long. But the Carline Thistle has a larger and more flattened flower-head, and when the flowers are in bloom they are of a purple colour, though they soon turn brown as they get dried up. 
Probably the nearest relation of the plant here photographed is the Common Fuller's Thistle (Circium oloraceum), abundant in moist places, both in the Alps and lowlands. It is a plant that would seem to be protected by its resemblance to other members of its family, for though it appears spiny, it is soft and succulent, and bears not a single prickle anywhere. The leaves, which are sparsely distributed on the slender stem, are of a dirty grey-green colour, and though as tall as its spiny relative, the plant is much less robust. 


\section{The Round-Headed Rampion}

(PHI TEUMA ORBICULARE)

IN England we have only two kinds of Rampion and both are rare, but in Switzerland there are no less than ten different species, with blue and white flowers, and some of them are extremely abundant. One of the commonest of the blue-flowered varieties is here photographed. It grows in mountain pastures and poor meadows between 3000 and 8000 feet, and is found not only in the Alps but all over Central Europe, though absent in the North. It flowers in July, and the size of the plant undergoes considerable variation according to the altitude at which it grows. Sometimes the flower-stalks are but 3 or 4 inches long, at others 16 or 18 . The leaves, which grow from the root stock, have serrated edges, and are frequently a good deal larger than those of the specimen photographed. The methods adopted by the plant for the distribution of its pollen and the fertilisation of its seeds through the agency of insect visitors are of particular interest. Each flower of the flower-head is formed of a blue tubular structure (corolla), which is at first closed above. In the centre of this is the style covered by short hairs and surrounded by the five stamens. While still in the bud the stamens shed their pollen, which collects in the tube around the style and is retained in position by the short hairs. Now the flower opens at its tip, and while 


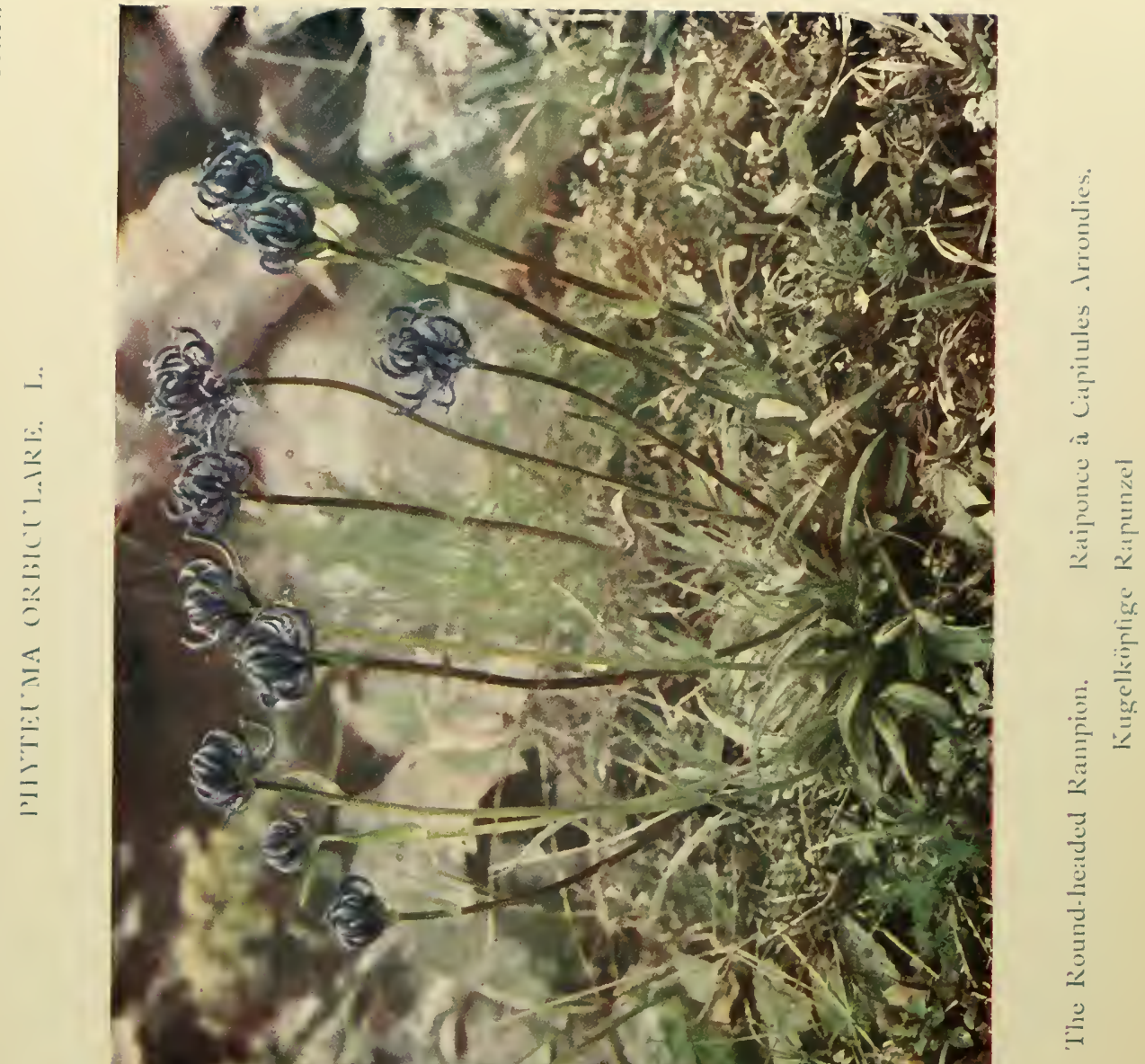



maintaining its tubular character above splits longitudinally below into five or six segments, so that linear openings are formed. The result is that when an insect settles on the flower the tubular corolla is very easily depressed, exposing the style surrounded on all sides by pollen. Any pollen that is not removed by the insect falls from the style, for the short hairs on the style by which it is held in position very soon fade. The style then splits above into three segments, exposing for the first time the sticky stigmatic surface now ready for pollination.

The Round-headed Rampion is one of the five Swiss species with rounded, not elongated, flower-heads. Three of them can at once be put aside, because they are usually much smaller plants and have less than twelve flowers to a flower-head, whereas the Round-headed Rampion has always more. Phyteuma Scheuchzeri is distinguished from this plant by its lilac flowers, longer stalked and usually broader basal leaves, and especially by the circle of leaves immediately beneath the flower-head, which are longer than the flowers themselves. 


\section{The Bearded Bell-flower or Campanula}

(CAMPANULA BARBAT A)

OF the numerons Bell-flowers which abound in the Alps none is more quaint and beautiful than the one here photographed. The whole plant, stem, leaves, and flowers, is covered with short hairs, but around the mouth of the bell the hairs are longer and stiffer, and pure white. It is interesting to note that when cultivated in rockeries in England the hairy character of the plant almost entirely disappears. Some three to five pendent flowers are borne by each flower-stalk, all turned in the same direction. Occasionally a single flowered variety is met with, usually at a high altitude. The ordinary pale blue colour of the flower may disappear entirely, and specimens with pure white blossoms are not infrequent. The plant is found abundantly all over the Alps and SubAlps, in meadows and pastures, and to a less extent in open woods, from 3000 feet almost to the snowline (7000 to 9000 feet). It is usually less abundant on limestone than on other rocks. The Bearded Bell-flower is also met with in the Carpathians, Jura, southern parts of Norway, and in other mountainous districts in Europe. It is probably a native of the Alps.

No difficulty will be experienced in recognising the 
CAMINNLLA BARBATA. I.

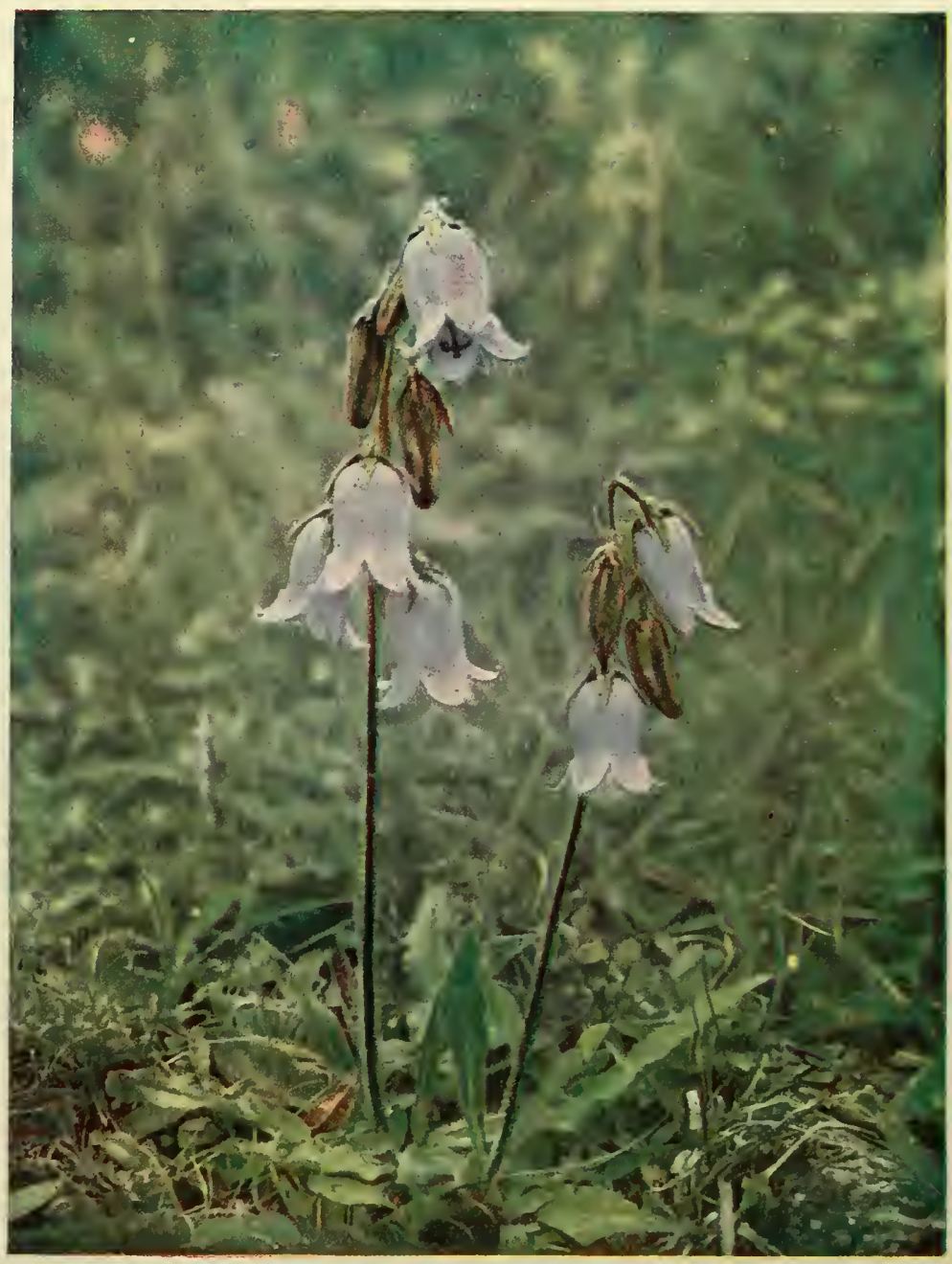

The Bearded Bell-flower or Campanula. Campanule Barhue. Birtige Glockenblume. 

Bearded Campanula. No other Bell-flower has little projections between each of the five teeth of the calyx which are turned back towards the stem. Only one other Bell-flower (Campanula Zoysii), and that a species not always recognised as distinct, has a light blue corolla with long hairs around its mouth. But here there is a constriction just immediately below the opening of the bell, and the plant is smaller and very rare, and occurs only in Eastern Switzerland. 


\section{The Dwarf Hair-Bell or Bell-Flower}

(CAMPANULA PUSILLA)

THE photograph gives a good general idea of the tufted growth of the Dwarf Bell-flower. The plant is quite small, rarely more than 3 or 4 inches high, and forms dense closegrowing tufts of some size. The smooth or hairy flower-stalks bear one to six pale blue flowers and the narrow leaves, which are most numerous and have serrated edges below. There are also short flowerless branches covered with similar leaves, and a few broader leaves with longer stalks grow directly from the root stock. These last are not well seen in the photograph. The plant is very abundant in dry rocky and sandy places, in dried up torrent-beds, by the roadside and on the tops of walls. It is found from the lower mountain region up to some 8000 feet, and descends with some of the rivers towards the plains. It is also found in the Jura and parts of the Black Forest.

The Dwarf Bell-flower will be recognised from most of the other species of Campanula which abound in Switzerland by its broad basal leaves, its narrow stem leaves, and its erect seed pod. But, unfortunately, there are three other Swiss species to which this description equally well applies. Of these the rare Campanula excisa is at once picked out 56 


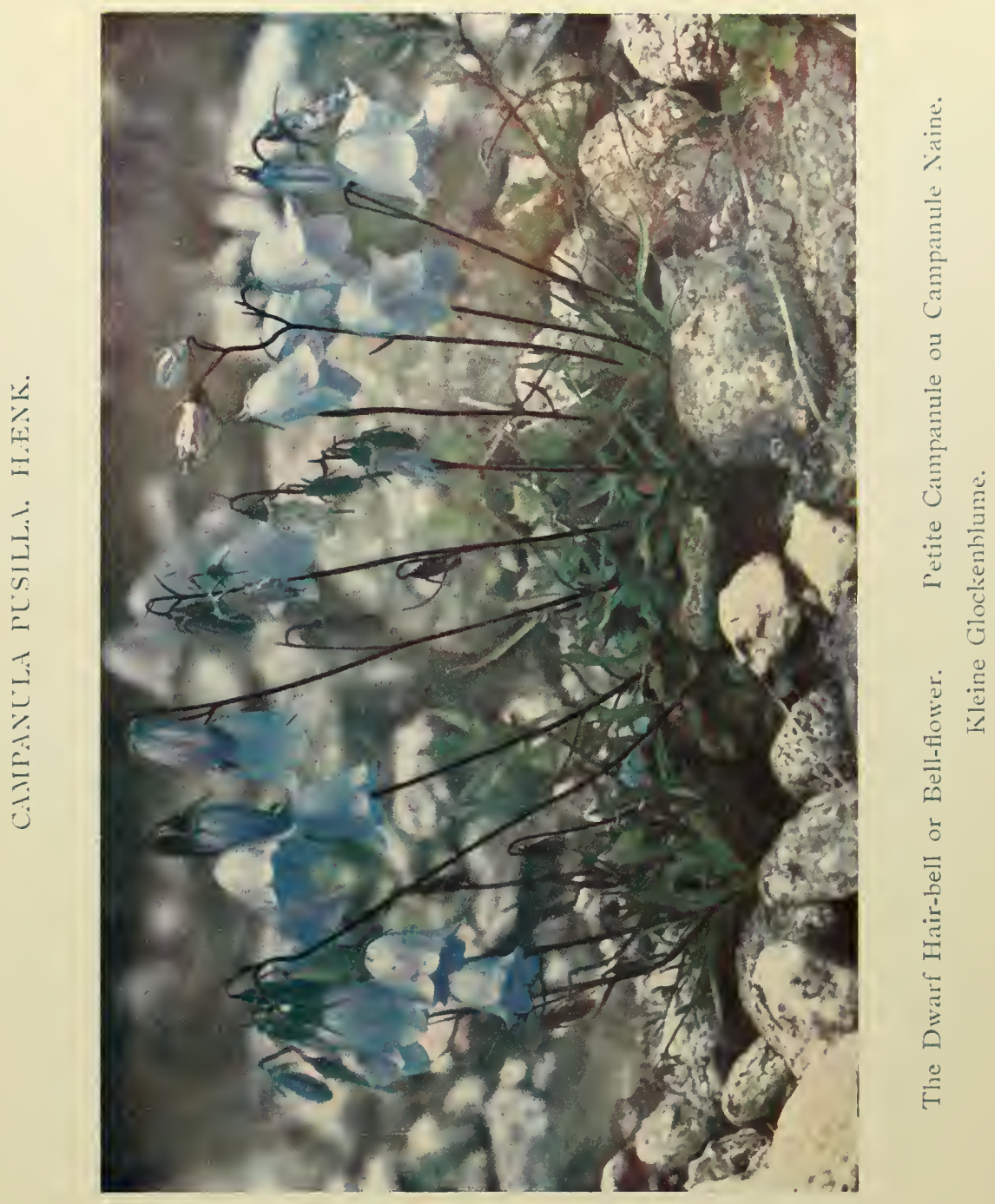


by the deep rounded clefts between the five segments of its bell-shaped flower. Campanula Scheucbzeri is a larger plant of more open and less tufted growth and with fewer flowerless leafy shoots. Its bell-shaped flowers are usually of a darker blue, are more conical, and have a wider opening; they are, in fact, less truly bell-shaped. Campanula rotundifolia, the common Hair-bell of our heaths and downs, which occurs also in Switzerland, is slightly taller than our plant and has also more cone-shaped flowers. Its flower buds are held erect, while those of the other three Bellflowers we are considering are dependent. In a general way, the low stature and tufted growth of the Dwarf Bellflower will, in most cases, suffice for its recognition. 


\section{The Hairy-Leaved Alpenrose (RHODODENDRON HIRSUTUM)}

The Alpenrose is the commonest and best known of all the Alpine plants. It abounds almost everywhere; were it not so it would have become practically extinct years before, for it is gathered unmercifully. Nor are the visitors to Switzerland alone responsible for this. Every Sunday throughout the summer, crowds of the native peasants, both children and adults, may be seen returning home, each bearing in his arms an immense bunch of the favourite flower, and often with a second and smaller nosegay tied round the top of his alpenstock.

There are really two distinct species of Alpenrose, the Hairy-leaved (Rhododendron birsutum), and the Rustyleaved (Rhododendron ferrugineum) varieties, and a hybrid or cross between them is also less commonly found. Both varieties are low evergeen shrubs with thick leathery leaves which only fade after three or four years. Both have raised brown spots on the lower surfaces of the leaves, only they are much more numerous on the Rusty-leaved species, so that the under surface of the leaf is completely covered with them while they are only sparsely scattered on the leaf of the Hairy-leaved variety. They contain a balsam, and are thought to be of use to the plant in preventing its drying up. They may also assist in the absorption of water. The 
RHODOIOENDRON HIRSETEM. I.

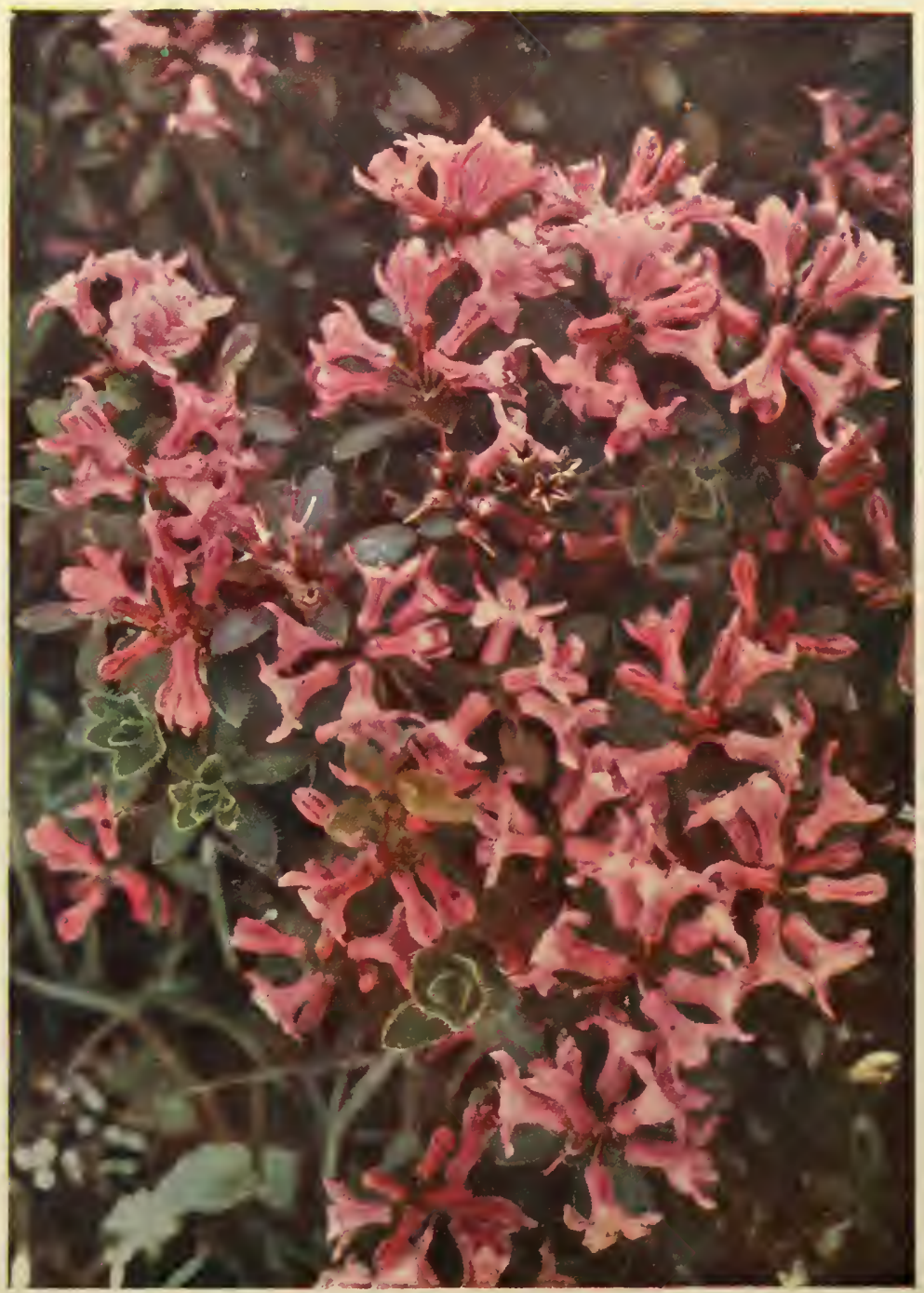

The Hairy-leaved Alpenrone. Rhododendron cilie ou herisese. Bewimperte Alpenrone, vder Wimpern-Alpenrose. 
flowers of both species are admirably adapted for crossfertilisation by the humble-bees which visit them. The stamens first mature, and not until the great part of the pollen is shed does the stigma lengthen and become ready for pollination. The long hairs growing from the stalks which bear the stamens interlock with similar hairs on the inside of the corolla, and thus effectively prevent the entrance of smaller insects which might visit the flower in search of the abundant honey, but which would fail to effect its fertilisation. The flowers of the species here illustrated are usually a little paler in colour, slightly smaller, and open a little later than those of the Rusty-leaved variety. The plant usually forms a lower and more thickly branched shrub, with rather shorter twigs. But the essential distinguishing features between the two are to be found in their leaves. The leaves of Rbododendron birsutum are usually broader and less pointed, green underneath, and have well-marked hairs all round their edges. In Rbododendron ferrugineum the leaves tend to be narrower, darker green above, and brown underneath, and are entirely devoid of hairs, but have rolled back edges. Both species are found abundantly in rocky places between 4000 and 8000 feet, and flower in June, July, and August, and may be seen at their best in July. The Rusty-leaved variety seems to prefer a rather moister spot and may also be found on peat. It is most abundant on primary granitic rock, while the other species grows best on limestone. 


\section{The Lesser Winter-Green}

(PYROLA MINOR)

THE plant here photographed derives its English name from the evergreen character of its leaves. It is in fact a British plant, being found somewhat rarely in Scotland and in the North, but is much more common in Switzerland. It grows among the moss in shady woods, from the plains right up to the tree-limit and may even reach 8000 feet or higher, where protected by shrubs and bushes. The plant is widely distributed in Switzerland and is also found in Vosges, Pyrenees, and Jura. It flowers in July.

The Lesser Winter-Green will be recognised by its short, straight style, which does not project beyond the flower and which is closely surrounded by the stamens which converge toward it. Of the four other Swiss Pyrolas which resemble the above, two only are at all common, and these two will alone be mentioned. Pyrola secunda will be recognised by its longer straight style, which projects beyond the petals and by its greenish white flowers, which are all turned in the same direction. Its leaves are more pointed and have deeper notches than those of our plant. Pyrola rotundifolia has also a style that projects beyond the petals, but it is curved so that the stigmatic surface at its extremity is far below the centre of the flower. 
PIROI.I MINOR. I.

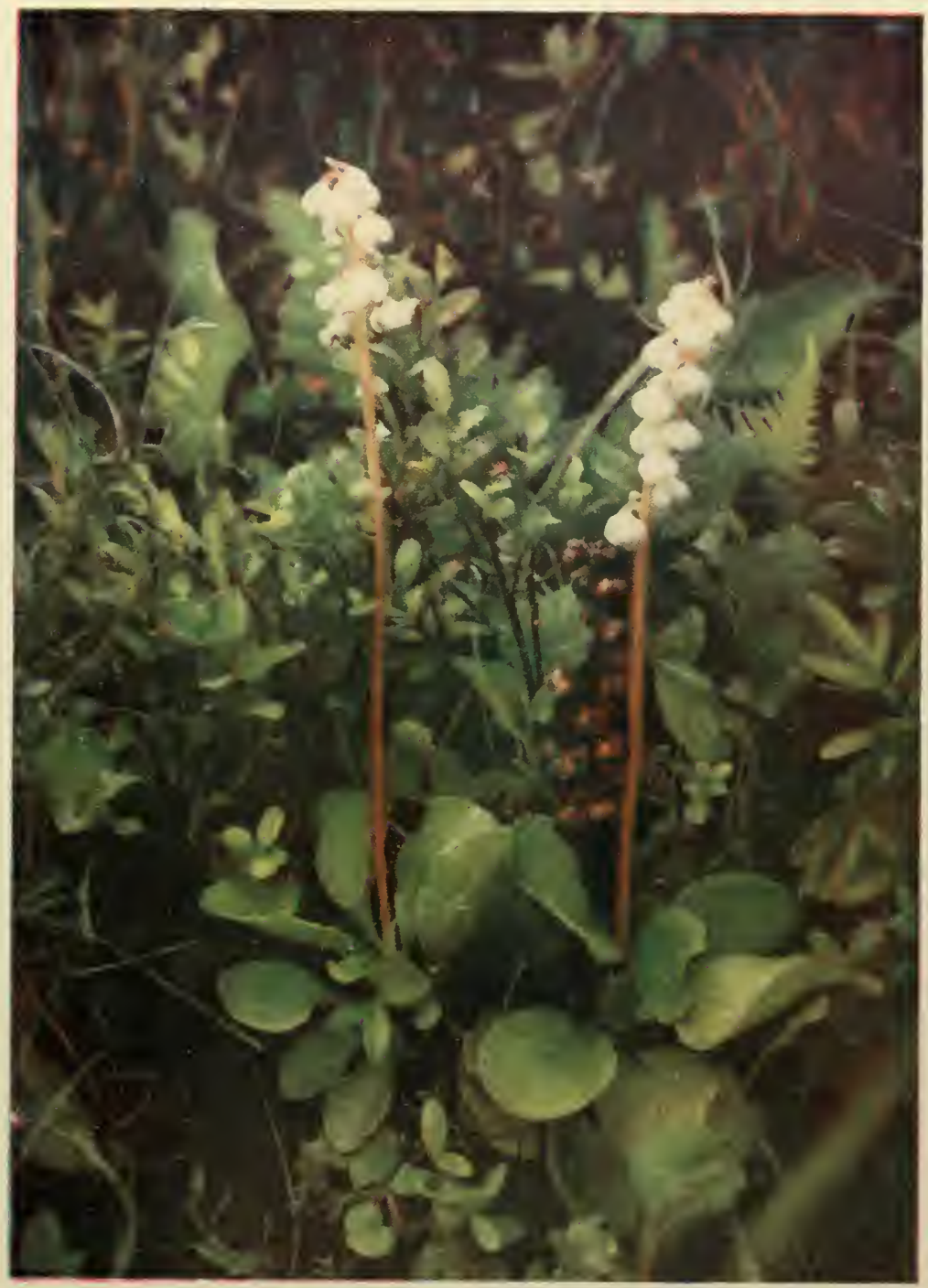

The Lener Winter-green. Petite l'yrole.

kleines Wintergrin. 



\section{The Stemless Gentian}

(GENTIANA ACAULIS)

MANy species of Gentian are met with in the Alps. One of the best known of the smaller varieties is the Stemless Gentian or Gentianella, which is a frequent inhabitant of heaths, meadows and pastures all over the higher parts of Switzerland, and is also found in the Jura and Carpathians, being less common on limestone soil and more abundant on primary granitic rock. The plant grows at an altitude of 4000 to 8000 feet, and flowers in June, July, and August. Occasionally it descends much lower and may even be found below 1500 feet in a few special localities. Each plant consists of a small rosette of leaves, a very short stem, and a single bell-shaped flower of deep azure blue. Very often two or three plants are found growing together and a small group such as that photographed is not infrequent. Occasionally also specimens with pale blue, rose red or even white flowers may be seen. When the flower has been fertilised, and while the seeds are maturing, the brightly coloured corolla shrivels up and surrounds the seed vessel, at the same time becoming of a green colour and perhaps taking on a vegetative function. The leaves are rather leathery, narrow, and pointed.

It is often quite a difficult matter to distinguish between the Stemless Gentian, here illustrated, and the Carved 


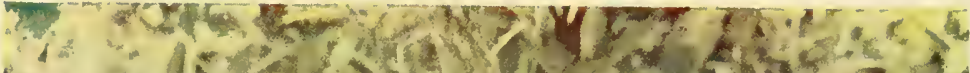

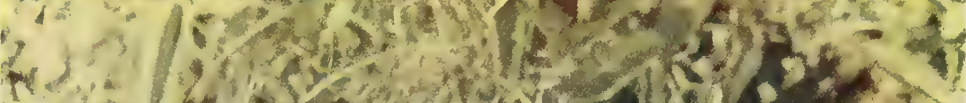

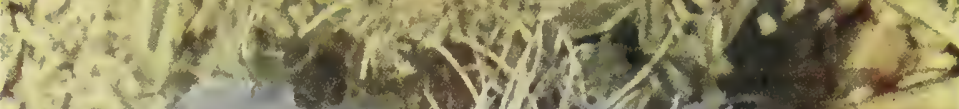

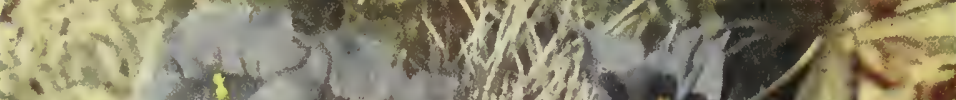

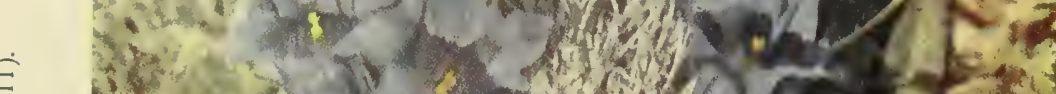



Gentian (Gentiana excisa), not only because the two plants are so much alike but also because intermediate forms exist; indeed, it is open to question whether the two plants are really to be regarded as distinct species. In the Carved Gentian the calyx lobes become contracted just above their bases, to widen out again abore, and the recesses between the lobes are more rounded and less pointed. The leaves also are broader, less leathery, and not nearly so sharp pointed as those of the so-called stemless variety. The flowers of the Marsh Gentian (Gentiana Pneumonanthe) are also not unlike those of the plant here photographed, but it should be readily distinguished because its leaves are much narrower and several flowers are borne by a single plant. 


\section{The Short-Leaved Gentian}

(GENTIANA BRACHTPHTLLA)

A particularly fine group of this beautiful little Gentian is here photographed. It is typical of the high Alps or snow region, and is rarely found below 6000 feet, and while scarce above 9000 is to be gathered even at I 2,000 feet on the Matterhorn. But a single flower is borne by each little plant at the top of a short stem, which also bears the small, thick, closely packed leaves. The plant is found growing in the turf of mountain pastures and rocky places in the central parts of the whole Alpine chain. It is moderately common particularly on primary rock, and is also met with in Dauphiny and the Pyrenees.

Of the twenty or more species of Gentian that occur in Switzerland, some are tall, stately plants, bearing numerous blue, yellow, or purple flowers. Others are much smaller and bear relatively few flowers, or even one only in small feeble plants. A few never have more than a single blossom to each little plant. Among these last are the Stemless Gentian with its bell-shaped flower, figured on the previous plate, and the Short-leaved Gentian with its star-like flower, which we here illustrate. As a matter of fact, there are really three single-flowered Star-Gentians and to distinguish between them is not easy. Of these the Bavarian Gentian (Gentiana bavarica) is recognised from our plant by 64 


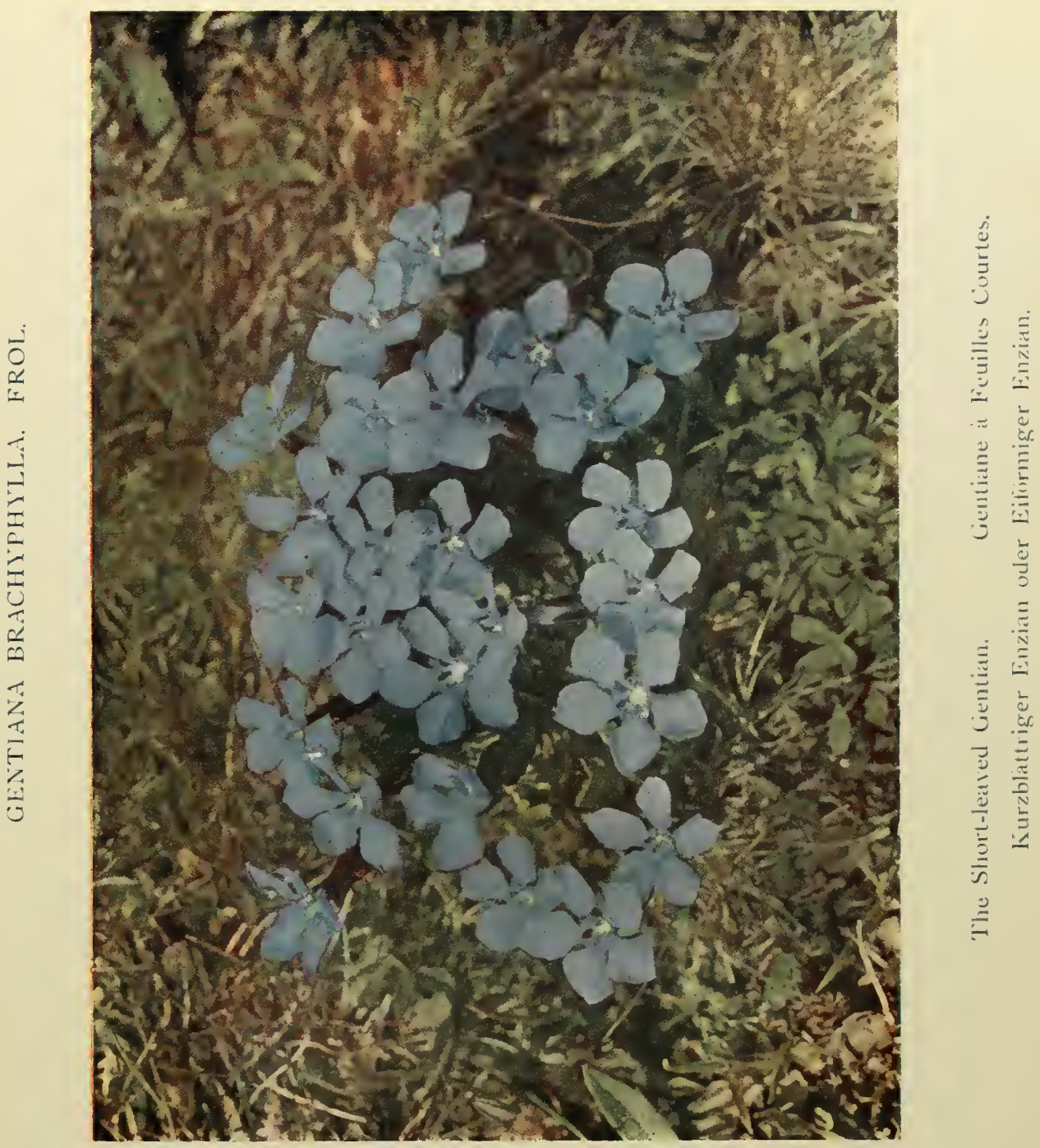



its longer stem, perhaps 2 to 3 inches long, on which only two or three pairs of opposite leaves are borne, and by the fact that the lower leaves are smaller than the upper. The Spring Gentian (Gentiana verna) has a very short stem, covered by closely packed leaves like the short-leaved variety, and like it, too, the lower leaves are the larger, but its leaves are harder, narrower, and more pointed, and short wing-like projections are found on its calyx. 


\section{The Alpine Toad-Flax (LINARIA ALPINA)}

Thrs beautiful little plant is abundant in all parts of the Alps. It is one of the first to take possession of fresh soil, but disappears rapidly under the stress of competition with other plants. Its numerous winged seeds are carried far and wide by the wind, and take root and grow rapidly on any open space. Hence it is found among the general rocky débris of the mountain-side, on the moraines of glaciers, and on the fresh soil brought down by avalanches, and is most abundant in limestone districts. Its true home is the high Alps and the snow region, and it flourishes best between 5000 and 9000 feet; but it is often carried down to a much lower level by the rivers, and is even found locally in the plains of Southern Germany. The Alpine Toad-flax is an inhabitant of most of the mountain ranges of Central and Southern Europe, and is thought to have taken origin in the South. It flowers from June till September, and seems to have derived its name from its flax-like foliage.

From the root stock arise one or more prostrate branches which creep over the rocks and soil, and turn upward at their extremities to terminate in a bunch of the brightly-coloured flowers. The grey-green leaves are narrow and succulent, and are arranged in whorls of four on the stem. The flowers are furnished with a long spur which contains the honey, 
$=$
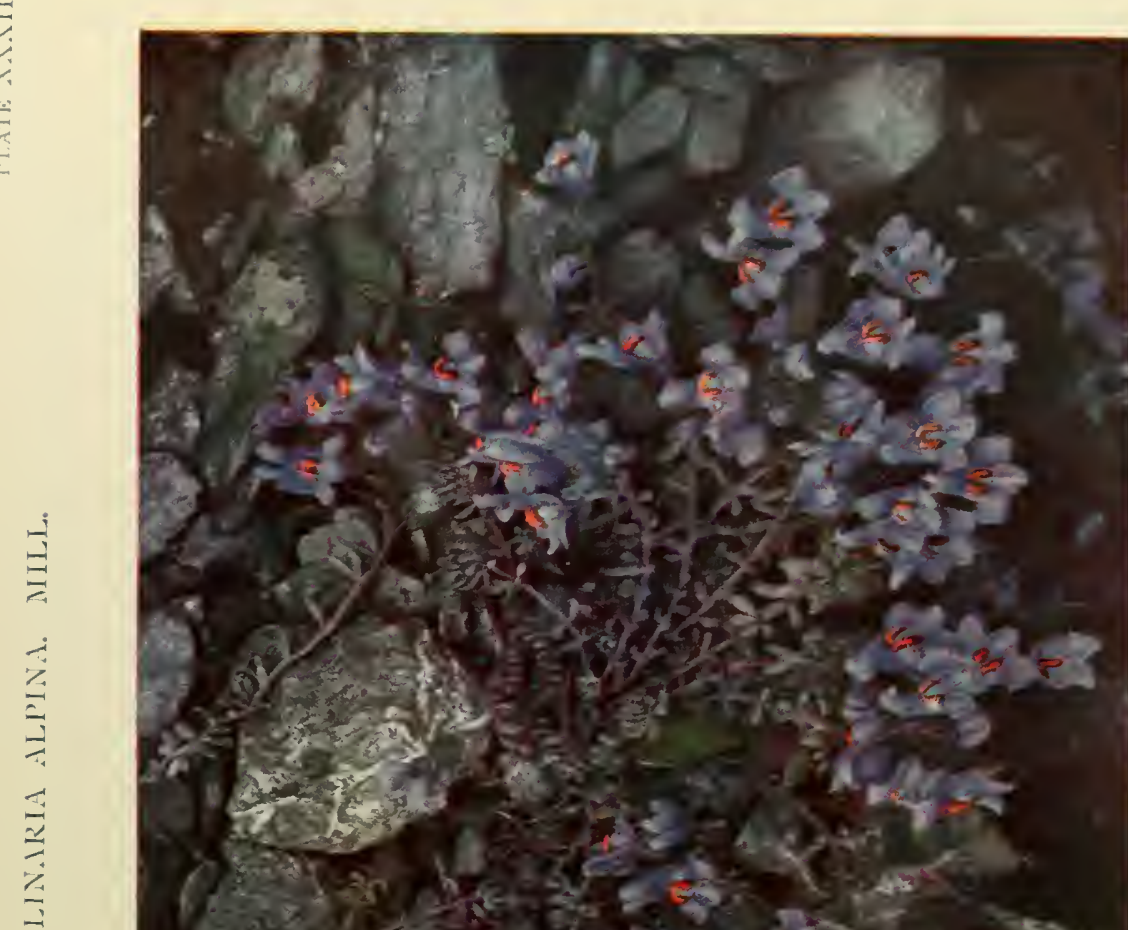

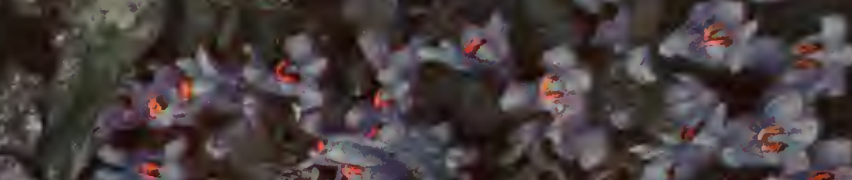
4.8.

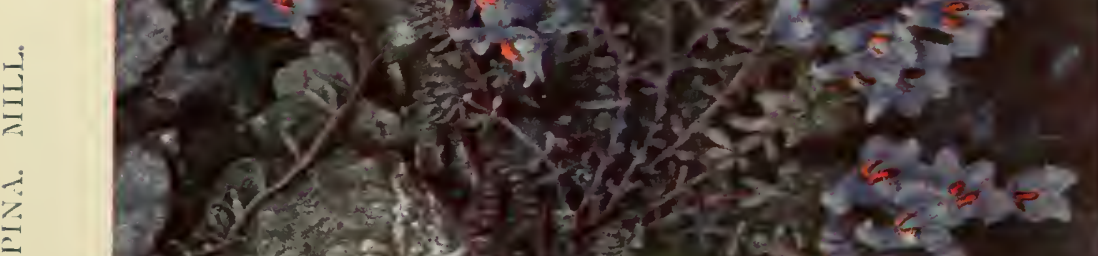

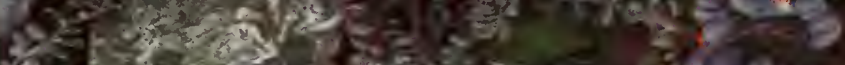

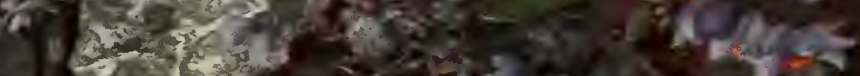

$\underset{z}{\beth}$

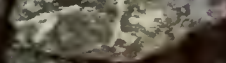

(1) 3927

$18 x^{2}=-1 x^{2}$

\section{$\frac{2}{4}+4,2+2$}

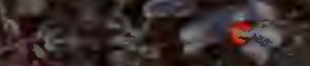

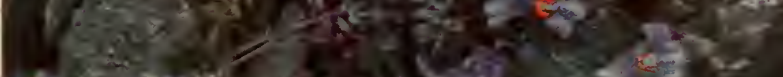
$\frac{4}{4}+\frac{1}{4}=$

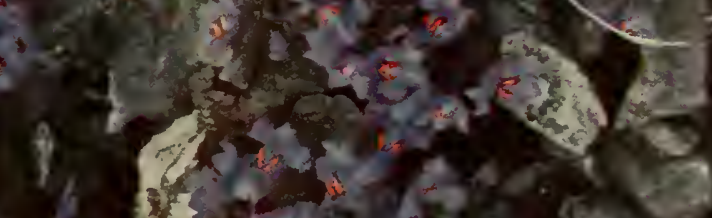

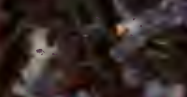

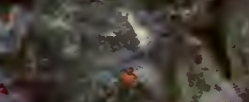

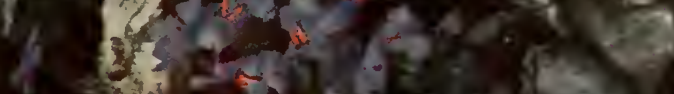

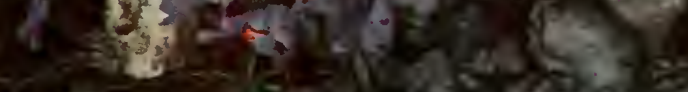

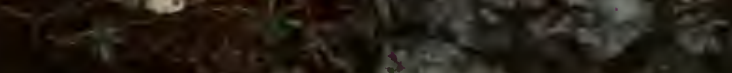


and are only visited by bees and humble-bees. The common humble-bee has a long enough tongue to reach to the tip of the spur and is the chief agent in the fertilisation of the plant. The orange-yellow spot at the only opening to the flower is equivalent to a notice "this way to the honey." Should no insect visit a flower self-fertilisation will nevertheless occur and seeds will be produced all the same. A variety of this plant, with flowers of a uniform red-violet colour and without any orange-yellow spot, grows on primary granitic rock. A second and much rarer type has pure yellow blossoms.

The plant is sure to be easily recognised. The prostrate stem, narrow leaves, and entirely closed up flowers that grow together in bunches are some of the more characteristic features. 


\section{The Alpine Balsam (ERINUS ALPINUS)}

The Alpine Balsam is a characteristic rock plant of the limestone Alps. Taking root in the clefts of the rocks, it sends out radiating branches in all directions, which adhere closely to the surface. It may also be sought in dry mountain meadows and among the grass of dry stony slopes, and is fairly common between 4000 and 7000 feet. Sometimes it is met with at a lower altitude in rocky places. The leaves, which are broader at their free extremities and covered by short hairs, are crowded together at the base of the stem. They have deeply serrated edges. The violet-purple or occasionally white flowers, which are formed of five petals united at their bases, are borne at the extremities of the branches. The Alpine Balsam is found not only in the Swiss Alps but also in the Tyrol, the Jura, the Vosges and Pyrenees. It flowers from early June till August.

The flowers of the Bird's-eye or Mealy Primrose (Primula farinosa) are not unlike those of the Alpine Balsam, at any rate at first sight. But each Mealy Primrose plant bears but a single leafless flower-stem which terminates in a cluster of flowers. Moreover, the Mealy Primrose is found in moist meadows and boggy places, and rarely among rocks, and its leaves have a grey, powdery bloom on their lower surfaces. 
$\vdots$
$\vdots$
$\vdots$
$\vdots$
$\vdots$
$\vdots$
$\vdots$

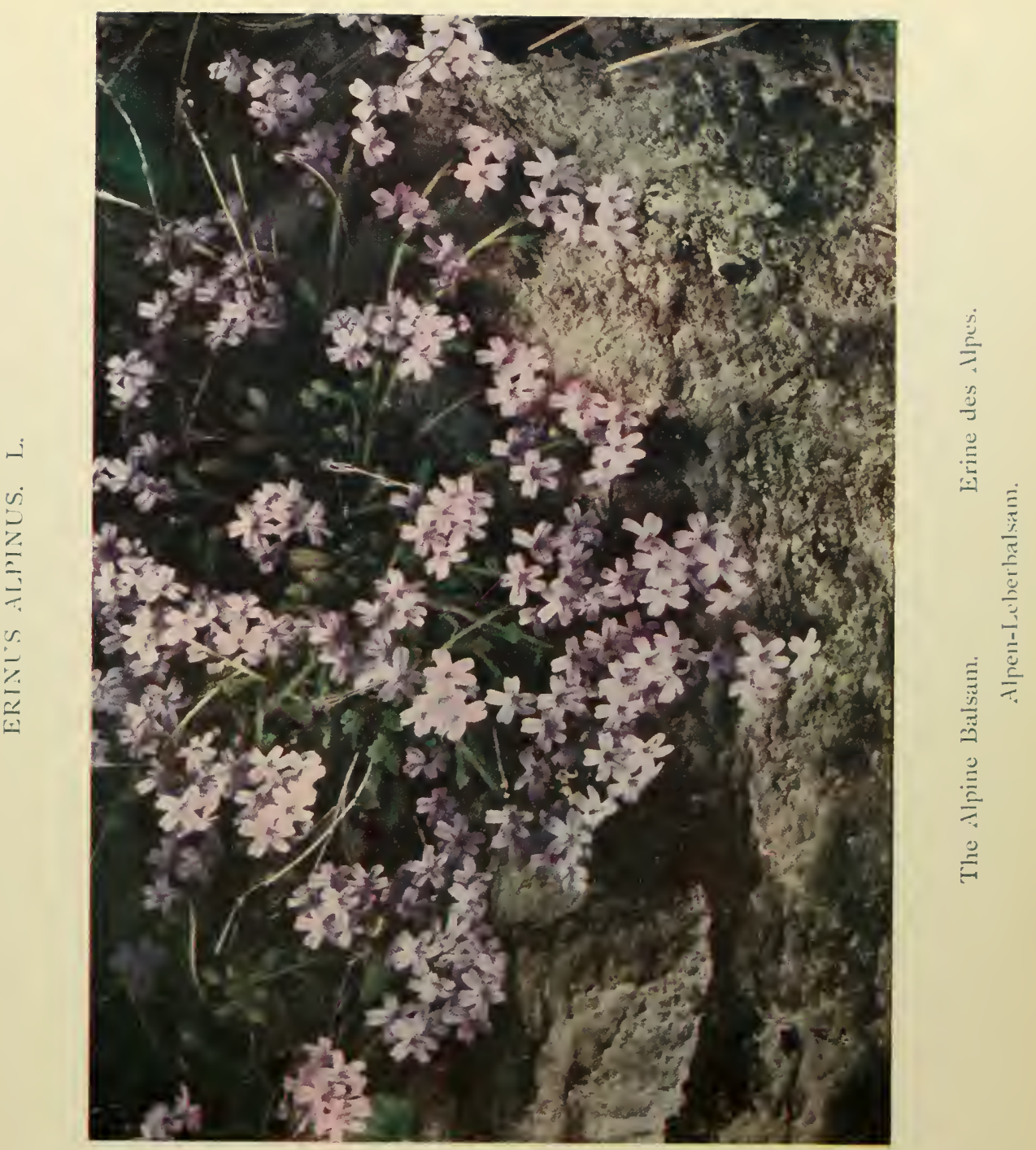






\section{The Leafy Lousewort (PEDICULARIS FOLIOSA)}

The Louseworts as a whole have been exceedingly successful in the Alps. No less than fourteen different species are to be found, and some of them are exceedingly common. In spite of their unpleasant name they are for the most part really beautiful plants, and as a group they are interesting in several ways. In the first place, they are all in some degree parasites on other plants. Branches arise from the roots which attach themselves to the roots of neighbouring plants and absorb from them water or salts or even organic nourishment. The Leafy Lousewort is not a great offender in this respect, but other species are capable of completely destroying many of the surrounding plants. The method of pollination of the Lousewort flowers is also somewhat remarkable. The flowers are only visited by humble bees, for no other insect appears to be strong enough to force an entrance into the flower. As may be made out from the photograph, the flower consists of two lips. In the upper is a vertical slit through which the stigma alone projects, but immediately behind the slit are the four stamens. The lower lip forms practically a landing stage for insect visitors. When the humble-bee alights on the flower his head is sure to come in contact with the projecting stigma and some of the pollen which he unconsciously carries with him will be removed. 


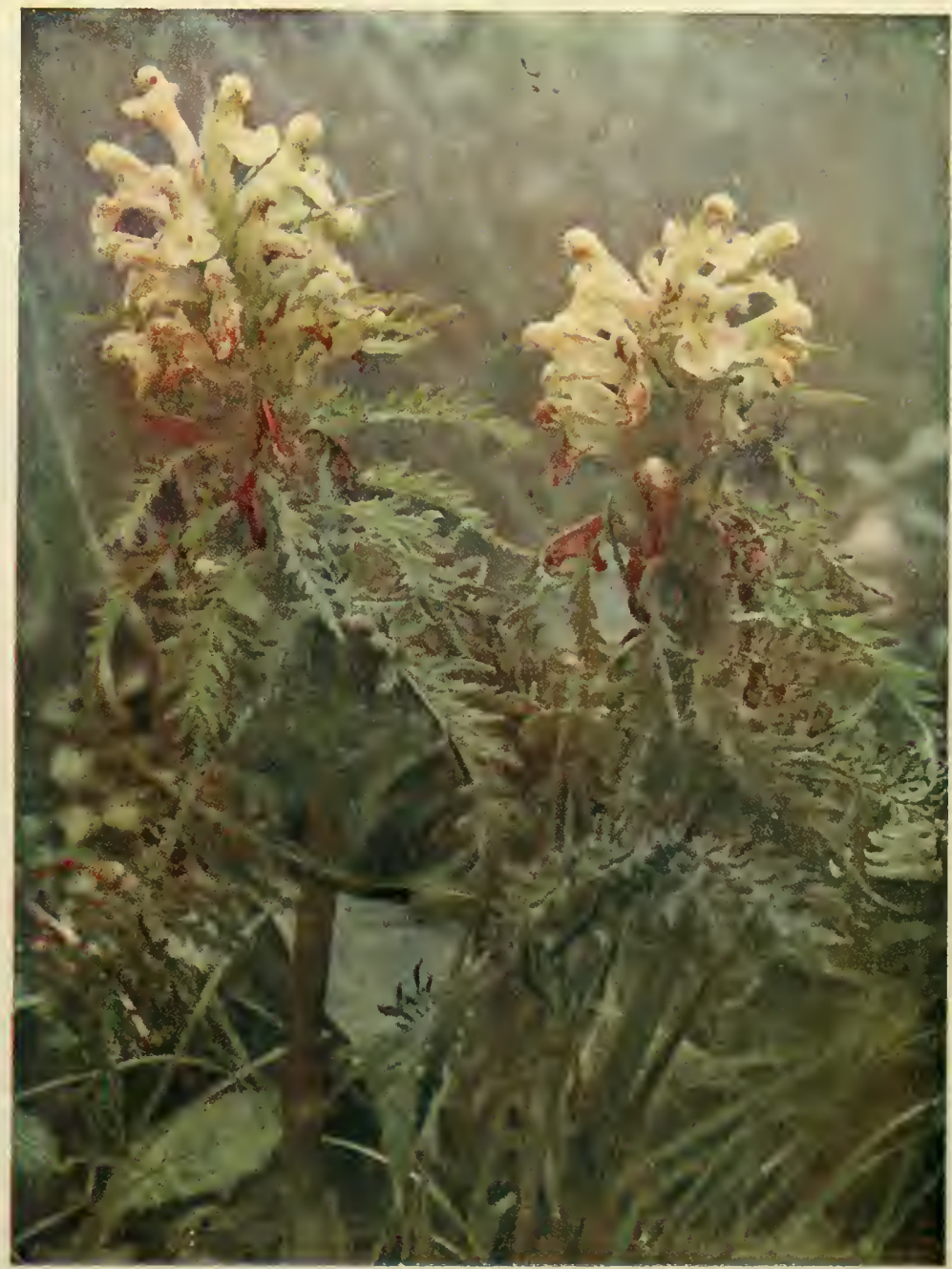

The Leafy Lousewort. Pédiculaire ì épi leuillé.

Reichbeblaittertes I,iucekraut. 

As he bends forward and thrusts his head into the flower to suck the honey the vertical slit in the upper lip will be widened out and the stamens will protrude and strike the insect's head. When the humble-bee at last leaves the flower to continue his journey its various parts will resume their former relative positions. Should no insects visit the flower self-pollination will occur. This appears to be the usual course of events in the North where humblebees are scarce. In Spitzbergen, where there are no humble-bees, a nearly-related species, Pedicularis lanata, is said to be regularly self-fertilised without apparently suffering in any possible way.

The Leafy Lousewort here illustrated is the commonest variety in most districts. It is a tall, stately plant, often some two feet high, which is found on grassy slopes and in rocky places between 3500 and 7000 feet, and grows best on a limestone soil. The large fine-divided leaves are even found among the pale yellow flowers on the flower-stem. The plant flowers in June and July, and is found in the Alps, Pyrenees, Vosges, and Jura. It will be readily recognised by its alternate leaves, and pale yellow hairy flowers, without any beak-like projection at their summits. Pedicularis Oederi, which is a little like it, has no foliage leaves between the flowers, which are devoid of hairs, and have a blackish red spot on either side of the upper lip. 


\section{The Yellow Auricula (PRIMULA AURICULA)}

Directry the snow melts up come the Auriculas, but only on limestone soil. The Auricula is really a spring plant, and usually flowers in May, but where protected by slowly melting masses of snow it may not bloom till much later; the accompanying photograph was taken in July. The thick, dense root-stock penetrates deep into the clefts of the rock. The leaves are smooth, rather fleshy, and of a bluish-green colour. The upper surface of the leaves, the flower-stalk and the calyx are covered with a white mealy substance. The leaves appear to serve the plant as a means of absorbing or storing water. Although the thick, dense cuticle usually present on leaves which have this function is here absent, they are found to dry up very slowly. It is probable that the thick cellulose walls between the individual cells replace the cuticle in the leaves of this plant. The flowers give forth a pleasant odour, something like that of the cowslip, but rather sweeter. Like the flowers of the primrose, they are of two kinds. The one has a long stigma which projects as far as the opening of the flower, and short stamens, and the converse is the case in the other. The object of this arrangement is to facilitate the pollination of the flowers by the agency of insect visitors as they pass from the one type to the other. Darwin found that very few seeds were formed when the flowers were self-fertilised. 
$\vdots$
$\vdots$
$\vdots$
$\vdots$
$\vdots$

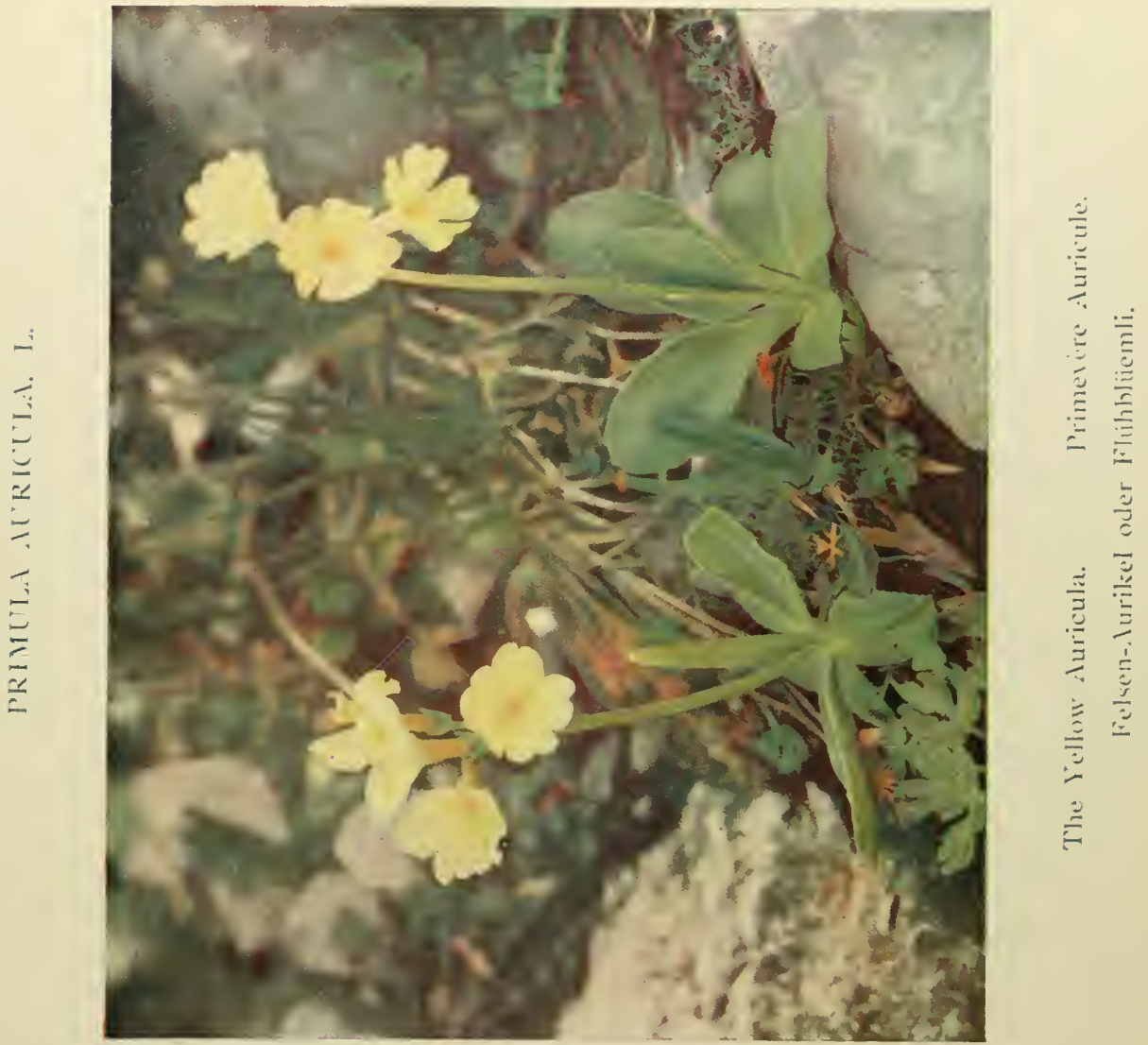



The Auricula grows in rocky places between 3000 and 7000 feet. It is only found in limestone districts, and is rather local. It is also to be met with in the Jura, Dauphiny, the Pyrenees, the Carpathians, and in one or two places in the Black Forest.

The Auricula will be readily recognised. From the Oxlip (Primula elatior) and Cowslip (Primula officinalis or veris), it is distinguished by its smooth, not wrinkled, leaves and mealy stem. It is probable that most of the brilliantly coloured garden Auriculas were originally derived from this species. 


\section{The Marsh Orchis}

(ORCHIS LATIFOLIA)

A LARGE number of Orchids are to be found in the Alps. They form a well-defined group of plants which are particularly interesting in view of complicated devices which they have adopted to ensure the fertilisation of their seeds by the agency of insect visitors. Nearly all the English species are found in Switzerland, and most of them are met with in much greater abundance there. The beautiful pink Helleborine, the sweet-scented Butterfly Orchis, may be found in profusion on the lower mountain slopes, and the dark red Nigritella, with its odour of vanilla, and the ghost-like Coral-root, in the higher regions.

Of the genus Orchis alone there are no less than seventeen Swiss species. Many of these are much alike, and by no means easy to distinguish from one another. One of the most abundant is the Marsh Orchis, which is also met with in England, but is not nearly so common there. The plant grows in damp meadows and boggy places, where an average sized plant may be 18 inches or two feet high. Its large purple spotted flowers appear in June and may last until July.

The methods adopted by the plant to ensure the fertilisation of its flowers by means of insect visitors are most elaborate and exact, but without the aid of diagrams they are a little difficult to explain. It is curious that no honey 
()R(HIS LATIFOLAA. L.

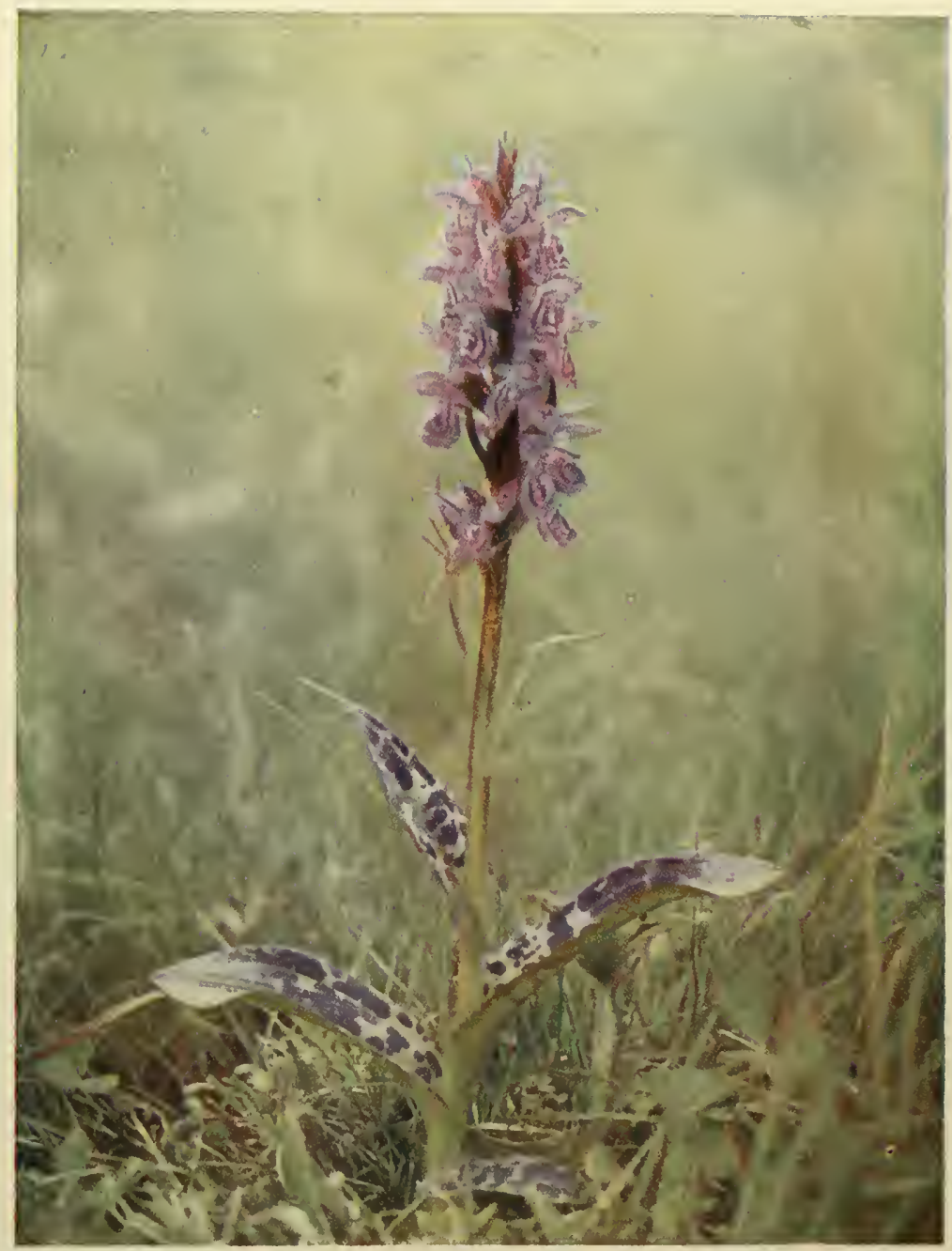

The Marsh ()ilis. L'()rchis a feuilles larges.

Breitblattriges Knabenkraut. 
is contained in the spur. It is probably the cell sap in it that is attractive to insects.

The Marsh Orchis will be recognised by its spreading spotted leaves, hollow stem, the palm-shaped tubers of its root, and the thick spur to the flower. 


\section{The Lady's Slipper (CYPRIPEDIUM CALCEOLUS)}

THis is one of the most striking plants of the Swiss flora, and while nowhere common is pretty widely distributed in the limestone districts of the Alps. It is a plant of some size, perhaps 12 to 24 inches in height, and grows in stony woods from the lower mountain region up to $6_{5} 00$ feet. One to three large yellow flowers are borne by each plant. Their method of fertilisation is of exceptional interest. Close to the attachment of the yellow slipper-shaped petal to the rest of the flower is a projection bearing on each side a stigmatic surface below and a mass of pollen above. The large yellow petal is smooth inside and has overhanging edges, rather like those of the familiar beetle-trap that is used for catching cockroaches, and as we shall see in a moment it acts in a similar manner. There is no honey in the flower, and it is not quite clear what the small bees that have been seen visiting it go there for. But at any rate when they once get in they have the greatest possible difficulty in getting out again, and only succeed in doing so by climbing up the attached side of the flower where the edges are not overhanging, that is on either side of the central projection. In doing this they are sure to brush first against the stigmatic surface, leaving behind some of the pollen they may chance to have sticking to them, and then against the viscid mass of 


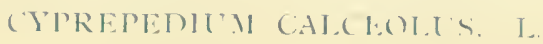

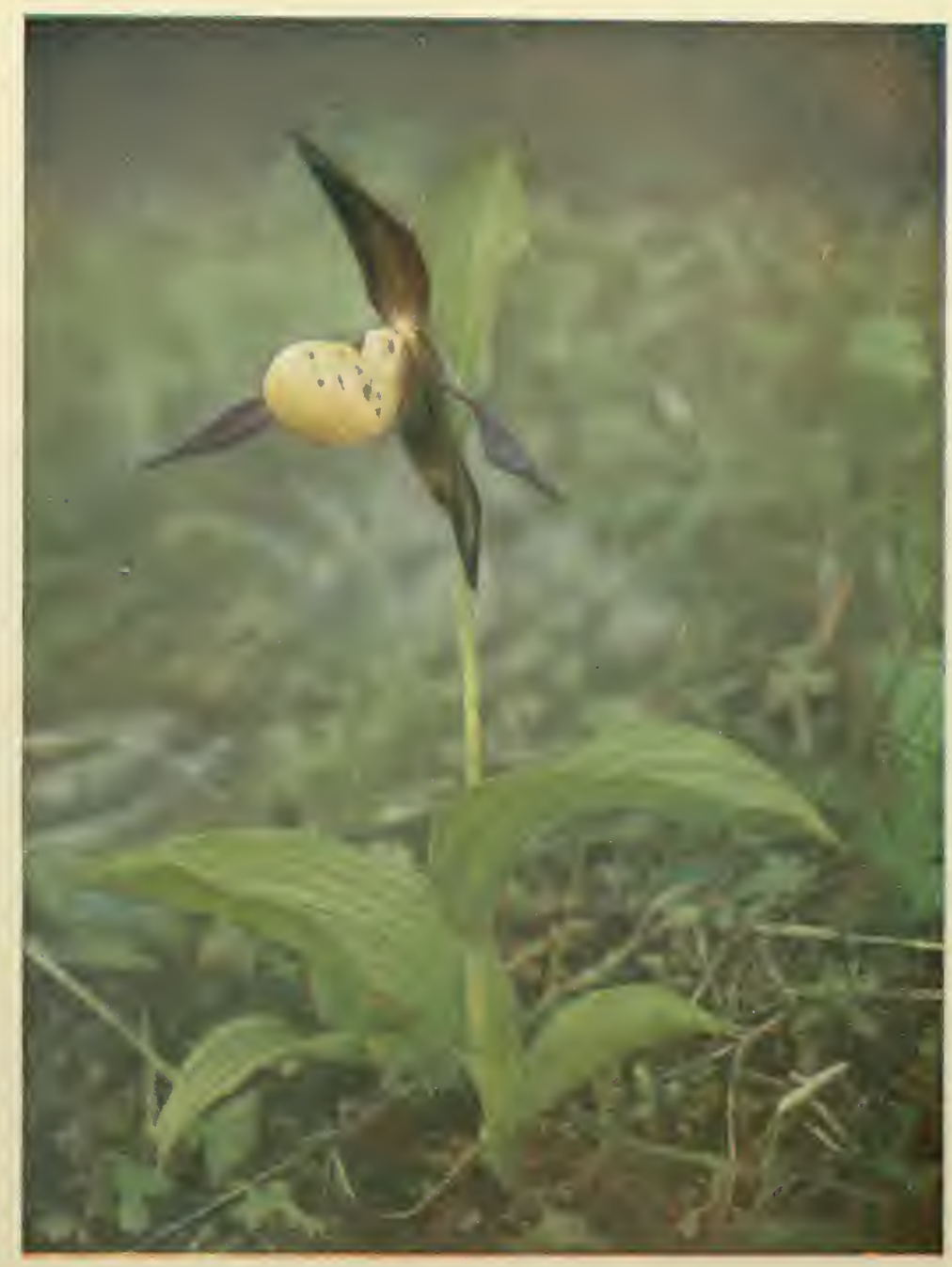

The Iady's-Slipper Orchid. Sahot de Vinus.

(iemeiner Fraucnsdhuh. 
pollen, some of which is sure to become attached to them. This process has been actually observed by Dr Herman Müller in the Alps.

The Lady's Slipper Orchid is found also in the Jura, Tyrol, Dauphiny, Pyrenees, in certain parts of Central and Southern Germany, and even in the North of England. It is everywhere rather rare, but specially so in this country. It flowers in May and June, and is sure to be easily recognised, for there is no other plant in the least like it.

No doubt such names as the Lady's Slipper, Lady's Mantle, and Lady's-Tresses refer to the dedication of the plant to the Virgin in mediæval times. The French name, "Sabot de Vénus," refers to a very different personage. A comparison between the English, French, German, and the scientific names, for the last of which Linneus is responsible, is a good example of the way in which the goddess Venus and the Virgin Mary were often confounded with one another in the early days. 


\section{The White Veratrum}

\section{(VERATRUM ALBUM)}

THE White Veratrum is a tall weed with large green leaves, very abundant in moist meadows and pastures in all parts of the Alps between 2000 and 6000 feet. Before the flowers appear it strongly suggests one of the larger Gentians, but the flowers, which come out in July and August, are quite different. It is a widely distributed plant, being found in Russia, Siberia, Lapland, as well as in most of the mountain ranges of Central and Southern Europe. It appears to have been left as a relic of the glacial period in the higher parts of Silesia and the Black Forest. The large green leaves are downy beneath, and the flowers, which are always green externally, may be pure white (var. typicum), or more commonly yellowish-green (var. Lobelianum), internally. Some would regard these two varieties as distinct species. The whole plant is extremely poisonous. Sometimes it is eaten by the sheep and goats with disastrous results to the herdsmen, but the cattle are wiser and rarely make this mistake. The poison is an alkaloid Veratrin, which is contained in largest quantities in the root from which it is extracted for medical purposes. If the root be tasted it will at first appear sweet, but its acrid, bitter flavour soon overpowers this first impression. The Swiss herdsmen look upon the White Veratrum as a noxious weed, not only because of its poisonous 
VERATRI.II ALIIC.M. I.

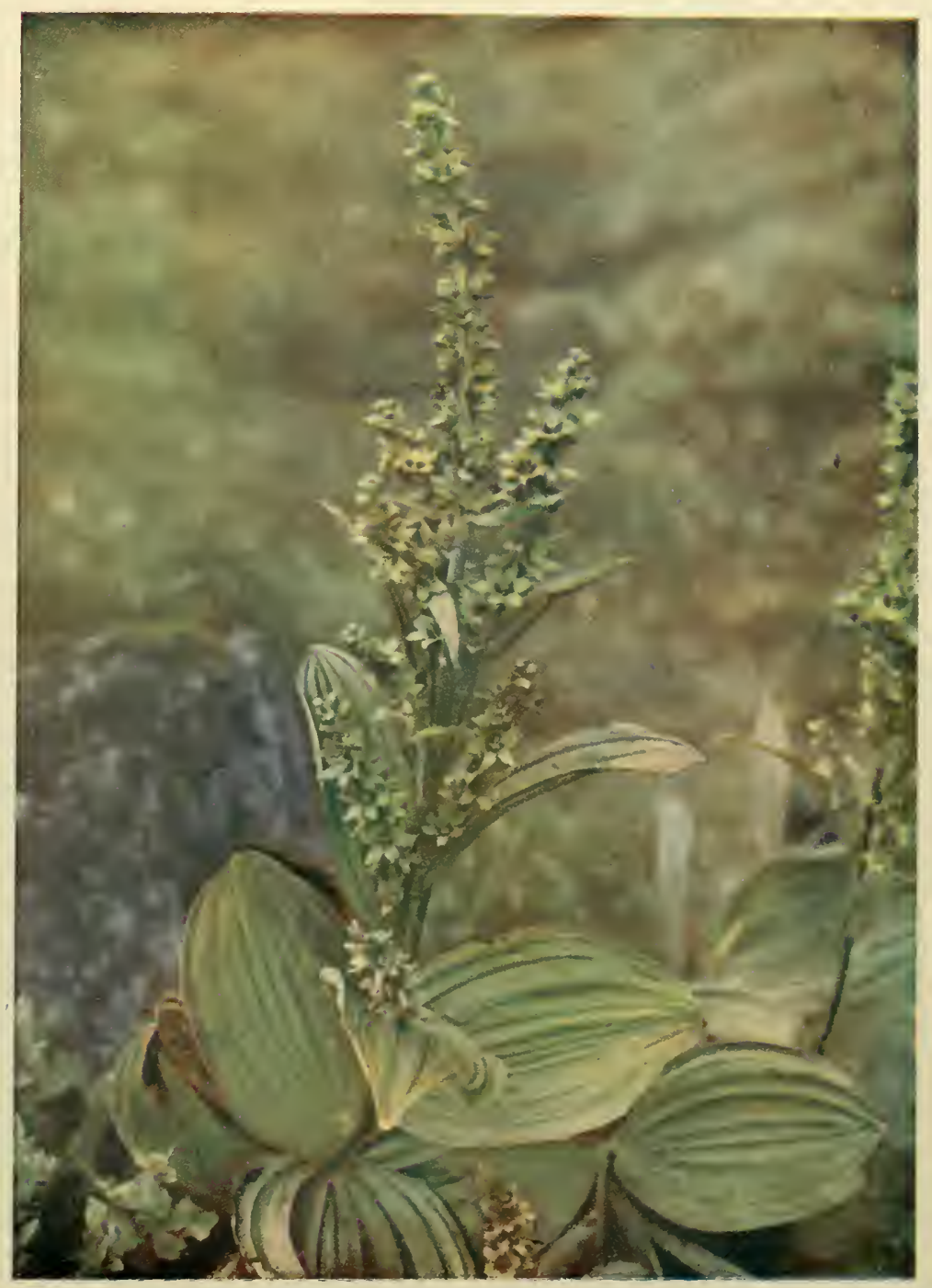

The White Veratrum. Hellébore blanc ou Viraire blanc. IVeisser Germer. 

properties but also because it grows in the richest soil and robs the true fodder plants of nourishment. In the Jura, on the other hand, the farmers rather welcome it. They say that the shade of its large leaves preserves the grass for the cattle and prevents it becoming dried up by the scorching sun.

The White Veratrum will be easily recognised. Its nearest relative, the Black Veratrum (Veratrum nigrum), is a much rarer plant that grows in woods. It has reddish-black or chocolate flowers, which grow in large spikes like those of the plant here illustrated, but each individual flower has a relatively longer flower-stalk. 



\section{Index}

A

Abies pectinata, xi

Aconites, 6

Aconitum Antbora, 8

"Lycoctum, 8

", Napellus, 6

, paniculatum, 7

Alpenrose, the Hairy-leaved, 58 " the Rusty-leaved, 58 Alpine anemone, 2

" Aster, 44

" Balsan, 68

" Carline Thistle, 50

", Clover, 22

"Fleabane, 44

" Honeysuckle, $x$

" Region, xii

" Rose, 32

" Sainfoin, 28

" Starwort, 44

Alps, xii

Altitude, $\mathrm{x}$

Anemone alpina, 2

, Narcissifora, 2

"nemorosa, 2

", Pulsatilla, 2

Antennaria carpathica, 47

" dioica, 46

Arnica montana, 48

Arnica, 48

Arolla, xii

Aronics, 49

Aster alpinus, 44

"Amellus, 45

Aster, the Alpine, 44

Astrantia major, 42
Astrantia, minor, 43

Astrantia, the Large, 42 the Small, 43

Auricula, the Yellow, 72

Auriculas, garden, 73

\section{B}

Ball, John, xxii

Balsam, the Alpine, 68

Bavarian Gentian, 64

Bearded Bell-flower, 54

Bell-flower, the Bearded, 54

Bird's-eye, 68 the Dwarf, 56

Biting Stonecrop, 4I

Black Veratrum, 79

Blood Geranium, 20

Bonnier, Professor, $x v$

Box-leaved Milkwort, I 4

Brook Crane's-bill, 20

Brown Clover, 24

Bupleurum ranunculoides, 43

\section{C}

Campanula barbata, 54

", excisa, 56

," pusilla, 56

" rotundifolia, 57

", Scheuchzeri, 57

" Zoysii, 55

Campanula, the Bearded, 54

Campion, the Moss, i 8

8 I 
Carlina acaulis, 50

Carline Thistle, the Alpine, 50

Carpathians Cudweed, 47

Carved Gentian, 62

Cat's-foot, 46

"Chamois' beards," 2

Chickweed, I 6

Christnas tree, xi

Circium oloraceum, 5 I

" spinosissimum, 50

Climate of Alps, $x i$

Clover, the Alpine, 22

" Brown, 24

Dull-flowered Sweet, 28

Cobweb House-leek, 37

Cold Milk-Vetch, 26

, Mountain-lentil, 26

Colours of Alpine flowers, xix

Common Fuller's Thistle, 5 I

" Milkwort, I 4

Cowslip, 73

Monk's-Hood, 6

Crane's-bill, Brook, 20

Creeping Gypsophila, 16

Crocuses, $\mathrm{XV}$

Cudweed, Carpathian, 47 " Mountain, 46

Cultivation of Alpine plants, xxiv

Cushion Pink, 18

"Cushion plant," I 8

Cypripedium calceolus, 76

D

Destruction of Alpine plants, xxiii

Dog-Rose, 32

Doronicum, 49

Dryas octopetala, 30

Dryas, the White, 30
Dull-flowered Sweet Clover, 26

Dwarf Bell-flower, 56

" Hair-Bell, $5^{6}$

E

Edelweiss, xv, xviii, 46

Epilobium angustifolium, 34

, Fleischeri, 34

" rosmarinifolium, 35

Erigeron alpina, 44

Erinus alpinus, 68

Eritricbium nanum, xiii

Evergreen Saxifrage, 40

Everlasting, the Mountain, 46

Eyebright, xix

\section{F}

Fleabane, the Alpine, 44

Fleischer's Willow-herb, 34

Flowers of Alpine plants, xix

Forget-me-not, xix

Fuller's Thistle, the Common, 5 I

" , the Spiny, 50

G

Gentian, the Bavarian, $\sigma_{4}$

", the Carved, 63

" the Marsh, 36

" the Short-leaved, 64

" the Spring, 65

" the Stemless, 62

Gentiana acaulis, 62

", bavarica, $6_{4}$

" brachyphylla, 64 
Gentiana excesa, 63

" Pneumonanthe, 63

" verna, 65

Geranium, the Blood, 20

", the Wood, 20

Geranium pratense, 20

$"$ rivulare, 20

, sanguinum, 20

, sylvaticum, 20

Glacial period, xxii

Glacier Crowfoot, xiii

Glaucium luteum, xiii

Globe Flower, 4

Gypsophila, the Creeping, 16

Gypsophila repens, 16

\section{$\mathrm{H}$}

Hair-bell, the Common, 57 the Dwarf, 56

Hairy-leaved Alpenrose, 58

Hare's-ear, 43

Hedysarum obscurum, 28

Horned Sea-poppy, xiii

House-leek, the Cobweb, 37

" the Common, 38

, the Mountain, 36

\section{I}

Insects in the Alps, xx

\section{L}

$\begin{array}{cc}\text { Lady's } & \text { Mantle, } 77 \\ , & \text { Slipper, } 76 \\ , & \text { Tresses, } 77\end{array}$

Larch, $x i$

Large Astrantia, 42
Larix Europea, x

Leafy Lousewort, 70

Lesser Winter-Green, 60

Linaria alpina, 66

Long-Spurred Pansy, 12

Lonicera alpigena, $\mathrm{x}$

Lousewort, the Leafy, 70

Low stature of Alpine plants, xvii

\section{M}

Maianthemum bifolium, $\mathrm{x}$

Marsh Gentian, 63

May-Lily, $x$

Meadow Crane's-bill, 20

Mealy Primrose, 68

Milk-Vetch, the Cold, 26

Milkwort, the Box-leaved, 14

" the Common, ${ }^{4}$

Monk's-Hood, the Common, 6

Moss Campion, 18

Moss-like Saxifrage, 41

Mountain Cudweed, 46

" Everlasting, 46

" House-leek, 36

" -lentil, the Cold, 26

Müller, $\mathrm{H}$., xx, xxi, 13

$\mathrm{N}$

Narcissus-flowered Anemone, 2

\section{$\mathrm{O}$}

Orchis latifolia, 74

Orchis, the Marsh, 74

Origin of Alpine flora, xxi

Oxlip, 73 
Panicled Monk's-hood, 7

Pansy, the I.ong-Spurred, I 2

Pasque Flower, 2

Pedicularis foliosa, 70

"lanata, $7 \mathrm{I}$

" Oederi, $7 \mathbf{I}$

Perennials in the Alps, xvi

Placa alpina, 26

, frigida, 26

Photography of Alpine plants, $\mathrm{xxv}$

Phyteuma orbiculare, 52

Picea excelsa, xi

Pinus Cembra, xii

", sylvestris, xii

Poa annua, $\mathrm{xvi}$

Polygala calcarea, 15

" chamabuxus, I 4

" vulgaris, I 4

Preserving Alpine plants, xxiii

Pressing Alpine plants, xxiii

Primrose, the Mealy, 68

Primula auricula, 72

" elatior, 73

" farinosa, 68

" officinalis, 73

" veris, 73

Pyrola minor, 60

$"$ rotundifolia, 60

" secunda, 60

\section{R}

Rampion, the Round-headed, 52

" the Whitc-flowered, $x$

Ranunculacee, 4

Ranunculus acris, 5

" glacialis, xiii
Ranunculus"montanus, 4

Red-berried Elder, $x$

Region of forest trees, $\mathrm{xi}$

Rhododendron ferrugineum, 58

Rock" gardens, xxiv

birsutum, 58

Rosa alpina, 32

Rose-bay, 34

Rose, the Alpine, 32

Rosemary-leaved Willow-herb, 35

Rough Saxifrage, 4I

Round-headed Rampion, 52

Rusty-leaved Alpenrose, 58

\section{S}

"Sabot de Vénus," 77

Sainfoin, the Alpine, 28

Sambucus racemosa, $\mathrm{x}$

Sandwort, I 6

Saxifraga Aizoides, 40

" aspera, $4 \mathrm{I}$

" bryoides, 4I

" Hirculus, 4 $\mathrm{I}$

", Sequieri, 4I

Saxifrage, the Evergreen, 40

" the Moss-like, 4I

Scotch Fir, xii the Rough, 4I

Sedum acre, $4 \mathbf{I}$

Sempervivum arachnoidium, 37

" Funckii, 38

, montanum, 36

" tectorum, 38

"Wulfeni, 38

Short-leaved Gentian, 64

Silene acaulis, 18

, exscapa, 19

Silver Fir, xi

Silver-herb, 30

Slipper, the Lady's, 76

84 
Small Astrantia, 43

Snowbells, xv

Spiny Fuller's Thistle, 50

Spiraa Aruncus, x

Spiræa, $x$

Spring Gentian, 65

Spruce, $x i$

Star-Gentians, $6_{4}$

Starwort, the Alpine, 44

Stemless Carline Thistle, 50

Gentian, 62

Stonecrops, 4 I

Stunted character of Alpine plants, xvii

Subalpine Region, xi

Sweet Clover, the Dull-flowered, 28

$\mathrm{T}$

Toad-flax, the Alpine, 66

Trifolium alpinum, 22

" badium, 24

" pallescens, 23

, spadiceum, 25

Trollius Europaus, 4

Two-flowered Violet, Io

\section{U}

Underground stem of Alpine plants, $\mathrm{Xv}$
Veratrum album, 78

" nigrum, 79

Veratrum, the Black, 79

Viola biflora, 10

", calcarata, 12

Violet, the Two-flowered, 10

W

White Dryas, 30

," Veratrum, 78

Willow-herb, Fleischer's, 34

, the Rosemary-leaved, 35

Winter-Green, the Lesser, 60

Wolf's-bane, the Yellow, 8

Wood Anemone, 2

" Geranium, 20

$\mathrm{Y}$

Yellow Auricula, 72

"Wolf's-bane, 8 

PRIN'SED BY

TORNBULL AND SPEARS,

EDINBURGH 




tiply

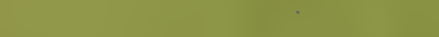
$x=$ $+1$

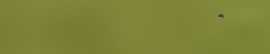
$=$
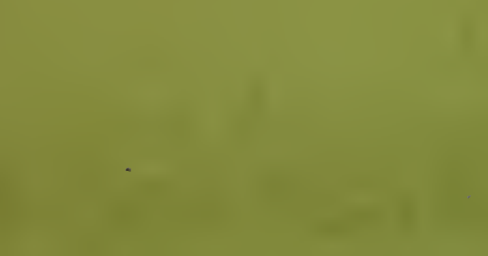

\section{. .}

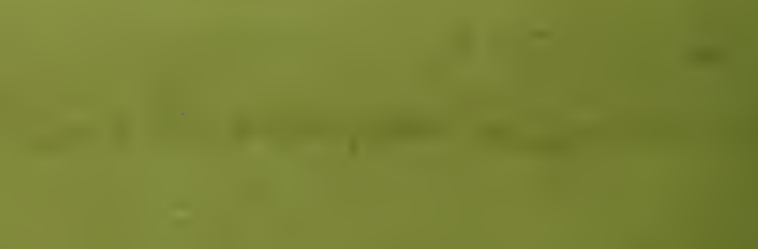

$-1$ 